\author{
Universidade de São Paulo \\ Faculdade de Filosofia, Letras e Ciências Humanas \\ Departamento de Letras Modernas \\ Programa de Língua Espanhola e Literaturas Espanhola e \\ Hispano-Americana \\ Renata Cristina Pereira Raulino
}

Amizade e memória múltipla:

Glosa, de Juan José Saer

São Paulo

2017 


\title{
Amizade e memória múltipla: \\ Glosa, de Juan José Saer
}

\author{
Versão original \\ Dissertação apresentada ao Programa de Língua Espanhola e \\ Literaturas Espanhola e Hispano-americana do Departamento de \\ Letras Modernas da Faculdade de Filosofia, Letras e Ciências \\ Humanas da Universidade de São Paulo para obtenção do título de \\ Mestre.
}

Orientadora: Profa. Dra. Adriana Kanzepolsky 
Autorizo a reprodução e divulgação total ou parcial deste trabalho, por qualquer meio convencional ou eletrônico, para fins de estudo e pesquisa, desde que citada a fonte.

Raulino, Renata Cristina

Amidade e memória múltipla: "Glosa", de Juan José Saer / Renata Cristina Raulino ; orientadora Adriana Kanzepolsky. - São Paulo, 2017. $113 \mathrm{f}$.

Dissertação (Mestrado) - Faculdade de Filosofia, Letras e Ciências Humanas da Universidade de São Paulo. Departamento de Letras Modernas. Área de concentração: Língua Espanhola e Literaturas Espanhola e Hispano-Americana.

1. Amizade. 2. Memória. 3. Romance. 4. Argentino. I. Kanzepolsky, Adriana, orient. II. Título. 
Renata Cristina Pereira Raulino

Amizade e memória múltipla: Glosa, de Juan José Saer

Dissertação apresentada ao Programa de Língua Espanhola e Literaturas Espanhola e Hispano-americana do Departamento de Letras Modernas da Faculdade de Filosofia, Letras e Ciências Humanas da Universidade de São Paulo para obtenção do título de Mestre.

Área de concentração: Literatura hispano-americana

Aprovada em:

\section{Banca examinadora}

Prof. Dr. :

Instituição:

Julgamento:

Prof. Dr. :

Instituição:

Julgamento:

Prof. Dr. :

Instituição:

Julgamento: 


\section{Dedicatória}

Aos meus pais, com amor e gratidão por sua compreensão, carinho, e me ensinar, entre muitas outras coisas, a valorizar a minha educação.

Ao Toquinho, meu tio Wagner e à minha avó Maria, mascote mãe e filho que se foram com tão pouco tempo de distância.

A Luci, minha melhor amiga, por co-sentir comigo e muitas vezes ser meu eixo. 


\section{Agradecimento}

À professora doutora Adriana Kanzepolsky, mentora e principal interlocutora, pelo apoio, pelo tempo doado e pela motivação desde que conversamos pela primeira vez.

Aos professores doutores Ana Cecilia Olmos e Jorge Bracamonte, componentes da banca de qualificação, pela generosidade e pelos essenciais comentários.

Ao CNPq pelo financiamento fornecido para o desenvolvimento desta pesquisa.

Ao grupo de estudos da profa. dra. Laura Janina Hosiasson pela acolhida e pelas conversas constantes.

Aos professores doutores Ana Copes e Rafael Arce pela acolhida no intercâmbio que fiz na Universidad Nacional del Litoral (Argentina) e que me permitiram adentrar com mais profundidade na "zona" Saer em um proto-projeto (que ficou só na promessa) de pesquisa em que um dos autores era Juan José Saer.

À Paulo Ricci pela generosidade, pela caminhada/conversa em um dia na Av. Paulista e pela dedicatória.

Aos amigos que foram, que permanecem e que virão. 


\section{RESUMO}

RAULINO, Renata Cristina Pereira. Amizade e memória múltipla: Glosa, de Juan José Saer. 2017. 113 f. Dissertação (Mestrado em literatura hispano-americana) - Faculdade de Filosofia, Letras e Ciências Humanas, Universidade de São Paulo.

Em Glosa (1986), romance do escritor argentino Juan José Saer (1937-2005), a relação privilegiada entre os personagens é a amizade. A (re)construção do vínculo acontece de forma singular ao longo do livro. Esse vínculo influencia nas perspectivas de um grupo de amigos que tentam reconstituir os acontecimentos de uma celebração - um churrasco em que se comemora um aniversário - desde o relato dos protagonistas que não estiveram presentes até as versões dos participantes do evento. Entretanto, as percepções e lembranças da festa não são suficientes para formar uma história próxima do que aconteceu. Pelo contrário, as glosas dos participantes da mesma festa não se complementam e se confirmam, mas se sobrepõem e se contradizem. Sendo assim, a rede de amigos que se encontra para conversar e discutir é o tecido básico sobre o qual as histórias se constroem. A partir disso, analisamos as possibilidades e limites do relato de lembranças compartilhadas e, ao mesmo tempo, múltiplas, como contribuição para o estabelecimento e manutenção de relações de amizade na narrativa, mesmo quando os amigos se dispersam principalmente por causa da última ditadura militar argentina.

Palavras-chave: Memória múltipla. Amizade. Glosa. Juan José Saer. 


\begin{abstract}
RAULINO, Renata Cristina Pereira. Friendship and multiple memory: Glosa by Juan José Saer. 2017. 113 f. Dissertação (Mestrado em literatura hispano-americana) - Faculdade de Filosofia, Letras e Ciências Humanas, Universidade de São Paulo.

In Glosa (1986), a novel by Argentine writer Juan José Saer (1937-2005), the privileged relationship between the characters is the friendship. The (re) construction of this bond happens in an unique way throughout the piece. This affection influences on the perspective of a group of friends who try to reconstitute the moments of a celebration - a barbecue in which a birthday is celebrated - according to the version of the main characters who were not present until the memories of the participants of the event. However, the perceptions of the party are not enough to build a reliable story of what really happened. On the other hand, the points of view about the same party do not complement each other, nor they are fact-checked, but they overlap and contradict each other. So the network of friends who meet to talk and discuss is the basic background in which stories are built. That said, we analyze the possibilities and limits of the narration of these shared and, at the same time, multiple memories as a contribution to the creation and maintenance of the characters' friendship in the novel, even when friends are spread out mainly because of the last Argentine military dictatorship .
\end{abstract}

Keywords: Multiple memory. Friendship. Glosa. Juan José Saer. 


\section{RESUMEN}

\section{RAULINO, Renata Cristina Pereira. Amistad y memoria múltiple: Glosa, de Juan José}

Saer. 2017. 113 f. Dissertação (Mestrado em literatura hispano-americana) - Faculdade de Filosofia, Letras e Ciências Humanas, Universidade de São Paulo.

En Glosa (1986), novela del escritor argentino Juan José Saer (1937-2005), la relación privilegiada entre los personajes es la amistad. La (re)construcción del vínculo ocurre de manera singular a lo largo del libro. Ese vínculo influencia en los perspectivas de un grupo de amigos que intentan reconstruir los acontecimientos de una celebración - un asado que se conmemora un cumpleaños - desde el relato de los protagonistas que no estuvieron presente hasta las versiones de los que asistieron al evento. Sin embargo, las percepciones y recuerdos de la fiesta no son suficientes para formar una historia más cercana a qué pasó. Por el contrario, las glosas de los participantes de la misma celebración no se complementan ni se confirman, sino que se sobreponen y se contradicen. Siendo así, la red de amigos que se encuentra para hablar y debatir es el tecido básico sobre el cual las historias se traman. A partir de eso, analizamos las posibilidades y límites del relato de recuerdos compartidos y, al mismo tiempo, múltiples como contribución para el establecimiento y manutención de relaciones de amistad en esa narrativa, aun cuando los amigos se dispersan a causa de la última dictadura militar argentina.

Palabras-clave: Memoria múltiple. Amistad. Glosa. Juan José Saer. 


\section{SUMÁRIO}

CONSIDERAÇÕES INICIAIS

1 CONFRONTO ENTRE AMIGOS, MULTIPLICIDADE DE LEMBRANÇAS 16

1.1 Dissonâncias $\quad 16$

$\begin{array}{ll}1.2 \text { Potências negativas } & 23\end{array}$

1.3 Experiências estético-narrativas

1.4 Dilatações, acidentes e tensões

$\begin{array}{ll}1.5 \text { Personagens } & 46\end{array}$

$\begin{array}{ll}\text { 1.5.1 Opacos } & 46\end{array}$

1.5.2 Múltiplos

2 FESTA, RISO, DOM

3. AMIZADE E POLÍTICA

$\begin{array}{ll}3.1 \text { Leveza } & 73\end{array}$

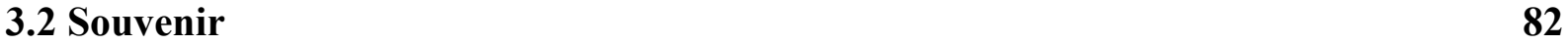

$\begin{array}{ll}3.3 \text { Inadequação } & 94\end{array}$

$\begin{array}{ll}\text { BIBLIOGRAFIA } & 108\end{array}$ 


\section{CONSIDERAÇÕES INICIAIS}

Desde a primeira leitura de Glosa, nos chamou a atenção como a principal relação que se estabelece entre os personagens do romance é a amizade e como o compartilhamento de lembranças, próprias e alheias, influencia na manutenção desses laços. Sendo assim, esta pesquisa teve como objetivo principal investigar as razões pelas quais e as estratégias através das quais os personagens de Glosa (1986), integrantes de um grupo de amigos, glosam em conjunto lembranças diferentes de um mesmo acontecimento importante para o círculo afetivo. Nesse romance de Juan José Saer (1937-2005), tais recordações (re)constroem uma mesma celebração por meio de uma superposição de pontos de vista.

A partir disso, nos indagamos em que medida a construção de uma memória múltipla possui um papel determinante no estabelecimento e manutenção de relações de amizade, laço afetivo nuclear no romance.

No texto em questão, a amizade é um afeto que aparece antes mesmo da narrativa começar. O autor dedica Glosa a três amigos "por las sobremesas del domingo". Esse tempo de conversas posterior à comida será privilegiado na evocação da lembrança por parte dos protagonistas Além disso, nessa mesma dedicatória, o romancista oferece aos amigos uma comédia. De fato, o humor é o tom que se busca na maior parte da narrativa de diversas maneiras como, por exemplo, um narrador externo que, sempre e exageradamente, põe em dúvida o que ele mesmo diz e percebe.

Leto e Matemático, conhecidos de um amplo círculo de amigos, encontram-se por acaso em uma das ruas centrais da "zona" saeriana. Essa é uma região que remete, apesar de nunca nomeada, à província argentina de Santa Fe (no caso de Glosa, o centro da capital), lugar de origem do autor e espaço (re)criado na sua obra. A evolução da caminhada é configurada em "cuadras" (100 metros) e é mostrada na divisão do romance: "Las primeras siete cuadras", "Las siete cuadras siguientes" e "Las últimas siete cuadras". Os dois caminham por esses quarteirões e conversam durante quase uma hora e centenas de páginas sobre uma celebração em que nenhum dos dois esteve presente: o aniversário de Washington Noriega, um dos membros centrais desse grupo de amigos. Em vista disso, ambos se valem das versões dos convidados que participaram da festa para comentá-la na caminhada.

Botón, convidado presente no evento, conta a Matemático sua lembrança sobre a festa e, a partir dessa versão, o protagonista cria e narra uma nova versão do mesmo acontecimento 
para Leto. Esse desconhece o lugar onde a celebração ocorreu e conhece poucos dos seus convidados e, por isso, ouve e imagina essa nova versão por meio de experiências próprias, mas alheias à festa evocada. Ou seja, a narração da festa por parte de Matemático, já uma modificação do relato da lembrança de Botón, se transforma na recepção de Leto. Portanto, o narrador externo à narrativa explicita desde o início que a lembrança alheia não pode ser apreendida da mesma maneira, na sua inteireza e fielmente.

Novas versões da festa de outros amigos que estiveram no aniversário surgem no decorrer da caminhada e possuem conteúdos bastante divergentes da primeira lembrança glosada. Tomatis, outro dos membros do grupo convidado, conta uma versão cáustica sobre o que se discutiu na festa quando se encontra com os protagonistas durante o passeio. Esse tom venenoso incide sobre o relato da lembrança do personagem e a torna diferente da lembrança de Botón.

Por sua vez, esse mesmo passeio se transforma em uma lembrança em si na memória de Matemático alguns anos depois da conversa com Leto e Tomatis. Em tal futuro, Matemático evoca novamente a mesma festa em outra caminhada, que realiza dessa vez com Pichón Garay, amigo que esteve presente na festa.

Em vista disso, os relatos aos quais os caminhantes têm acesso não convergem para formar uma história mais próxima do que realmente aconteceu. Pelo contrário, as versões dos participantes da mesma celebração não se complementam e se confirmam, mas se sobrepõem e se contradizem. Essa divergência de vozes remete a um dos sentidos do título do romance: "glosa" é uma variação musical que se executa com as mesmas notas. Sendo assim, os participantes do aniversário formam essencialmente três variações dissonantes do evento: Botón, Carlos Tomatis e Pichón Garay.

No mesmo futuro aludido acima, Matemático estará exilado na Europa devido à última ditadura militar argentina (1976-1983). Os efeitos do terrorismo de estado são outra experiência social importante para a pequena sociedade de amigos nesse romance e em outras narrativas do escritor. Muitos de seus integrantes sofrem os efeitos desse trauma histórico, recente no ano de publicação de Glosa (1986): o exílio, o desaparecimento, a guerrilha e a morte, sendo os dois últimos o futuro de Leto. Nesse sentido, no artigo "La importancia de Glosa en la obra de Juan José Saer, Jorge Bracamonte (2005) observa que os acontecimentos nímios e banais dão novos significados a macro-acontecimentos históricos: 
Si las memorias de Noriega, el Matemático y Leto (y con ellas las de Tomatis, Pichón Garay, Elisa y el Gato, entre otros) son significativas, es por aquello que las constituyó en tanto trayectorias y memorias personales que a la vez fueron involucradas, arrastradas y afectadas por el dinamismo del devenir histórico, sombrío en su desenlace [...]: el sentido de la historia adquiere entonces real compresión y explicación a partir de lo subjetivo e intersubjetivo (p. 256, grifo nosso).

Aparentemente, tal experiência histórica dispersa a rede de amigos da qual os protagonistas caminhantes do romance desejam tanto continuar a fazer parte integralmente.

Voltando à mesma conversa entre os personagens principais, o narrador mostra nas suas consciências outras lembranças que os desviam continuamente da conversa e sua tentativa de reconstituição da festa. Na consciência de Matemático, irrompe a lembrança do "Episodio", situação na qual também se viu excluído de um evento e de um grupo de intelectuais, nesse caso, o jantar com um poeta que visitava a cidade. No caso de Leto, há a constante volta das causas e efeitos do suicídio de seu pai, o que torna inacessível para o ouvinte e o leitor a conclusão do relato de Matemático acerca do que foi dito na celebração pelo aniversariante. Ou seja, a superposição angustiante das lembranças de Leto em torno a essa fatalidade familiar o impede de escutar partes do relato da festa que são importantes para a sua compreensão. Por exemplo, um dos fios da narrativa é a glosa de Matemático sobre reflexões absurdas de Washington Noriega acerca do comportamento de mosquitos. Tal fio é importante porque seria a conclusão do personagem central da festa sobre um debate que percorreu todo o relato da celebração: a possibilidade ou não do instinto de animais como cavalos e mosquitos permitir o erro. Essa inconclusão frustra a expectativa do leitor que, assim como Leto, desconhece o que Matemático comentou sobre a reflexão do aniversariante. Sendo assim, essas digressões, em especial as que correspondem a Leto, comprometem ainda mais o relato dessa experiência composta por pontos de vista múltiplos e díspares.

Assim sendo, esta pesquisa teve como propósito indagar em que medida e até que ponto a construção de um relato de lembranças contraditórias de um mesmo acontecimento contribui para o estabelecimento e manutenção de relações de amizade no romance. Para isso, observei como o exercício compartilhado da rememoração auxilia na continuidade do pertencimento dos protagonistas ao círculo de amigos e possibilita a criação de um laço afetivo entre Matemático e Leto, por mais que essa amizade incipiente seja incompleta, não isenta de dúvidas e pareça durar somente o tempo da caminhada. 
Esta dissertação se divide em três capítulos, sendo que dois deles estão subdivididos em subseções.

No primeiro capítulo, "Confronto entre amigos, multiplicidade de lembranças", apresentamos e analisamos a multiplicidade de versões da festa de aniversário de Washington Noriega e seus efeitos, subdividindo-se nas seguintes subseções:

- Em "Dissonâncias", mostramos como a confrontação das vozes que narram a celebração desvelam o tipo de laço afetivo que une os personagens: uma amizade baseada na disputa e na desconfiança da palavra da rede amigos;

- Em "Potências", analisamos como tal desconfiança é produtiva para a narrativa, uma vez que a dúvida em relação ao que se conta gera uma memória múltipla e, consequentemente, opaca sobre um mesmo acontecimento e possibilita a criação de um laço afetivo provisório entre os protagonistas de Glosa;

- Em "Experiências estético-narrativas", observamos como os protagonistas se ligam afetivamente por meio de experiências estético-narrativas, em especial a da narração da festa no tempo da caminhada;

- Em "Dilatações, acidentes e tensões", analisamos como a narração compartilhada da festa tece uma aproximação entre os protagonistas. Essa é acidental, se dilata no tempo da caminhada e possui uma tensão entre a união que a caminhada e a experiência da festa proporcionam e a separação suscitada pelas suas consciências e outras lembranças;

- Em "Personagens", nos detivemos no modo como as relações de amizade também incidem sobre a construção dos personagens;

Por sua vez, em "Dom", segundo capítulo, observaremos como no presente prazeirosamente dilatado desses encontros os amigos estão obcecados pela vida e pelas experiências sensoriais que o passeio e a festa lhes proporcionam. Amigos rivais riem uns das opiniões dos outros para intercambiar a experiência de uma amizade que não elimina, mas estimula o conflito que mantém a liberdade de brincar e conversar, sem com isso abrir mão de seus próprios pontos de vista em conversas inteligentes, mas não sérias.

O terceiro capítulo, “Amizade e política”, se divide nas três seguintes subseções: 
- Em "Leveza", mostramos como as relações de amizade nos tempos da caminhada e da festa evocada levam para um segundo plano narrativo as experiências dos personagens atreladas à política;

- Em "Souvenir", indagamos como nos anos terríveis da última ditadura militar argentina, a alegria sobrevive na memória e nos reencontros de um grupo de personagens ligados principalmente por laços de amizade. Diante das ruínas de suas relações de juventude, os amigos se reencontram principalmente em memória de um passado compartilhado que sobrevive em restos de lembranças, como um souvenir. Esse é um objeto que os sujeitos conectam a determinado momento importante de suas vidas, tornando material um referente abstrato;

- Em "Inadequação", mostramos como esses efêmeros encontros entre amigos vão contra o poder, resistindo à redução de uma representação melodramática dos efeitos do Terrorismo de Estado. 
Una narración podría estructurarse mediante una simple yuxtaposición de recuerdos. [...] Se trataría más bien de una narración circular y la posición del narrador sería semejante a la del niño que, sobre el caballo de la calesita, trata de agarrar a cada vuelta los aros de acero de la sortija (SAER, 1998, p. 190).

\section{CONFRONTO ENTRE AMIGOS, MULTIPLICIDADE DE LEMBRANÇAS}

\subsection{Dissonâncias}

Em Glosa, as relações privilegiadas entre os personagens não são as familiares ou as românticas, mas as de amizade. Os amigos se encontram principalmente em dois lugares: um "asado" (churrasco) e uma caminhada compartilhada. O narrador acompanha os pensamentos e a conversa de Matemático e Leto, dois membros desse círculo de amigos, em um passeio pelas 21 quadras da zona saeriana ${ }^{2}$. A dupla fala sobre o churrasco em comemoração ao aniversário de Washington Noriega, figura importante para esse grupo. Essa confraternização tinha ocorrido há certo tempo, mas nenhum dos dois caminhantes compareceu. Em vista disso, ambos se valem das versões dos convidados que participaram da festa para comentá-la na caminhada.

Dois significados do título polissêmico ${ }^{3}$ do romance são importantes para o início deste estudo. Em primeiro lugar, "glosa" é um comentário de segunda mão de certo acontecimento. $\mathrm{Ou}$ seja, narrador e protagonistas são os principais comentaristas da festa justamente porque não a viveram diretamente, mas sim por meio das versões dos convidados presentes.

No entanto, os relatos aos quais os caminhantes têm acesso não convergem para

\footnotetext{
${ }^{1}$ Em El río sin orillas (1991), Saer explica que um "asado" não é somente comer a carne bovina, mas também o lugar onde se come, a ocasião, a cerimônia. Por isso, o evento é um espaço de reencontro de amigos e de interlocução intelectual predominantemente masculina na narrativa em análise.

${ }^{2} \mathrm{O}$ romance se divide de acordo com a evolução da caminhada dos protagonistas, em "cuadras" (100 metros): "Las primeras siete cuadras", "Las siete cuadras siguientes" e "Las últimas siete cuadras". Esse percurso está no centro da capital da zona saeriana, região que remete à província argentina de Santa Fe, lugar de origem do autor e espaço (re)criado na sua obra.

${ }^{3}$ De acordo com a nota número 1 da edição crítica de Glosa e El entenado (2010), o título tem os seguintes sentidos possíveis: (a) comentário de um texto ou acontecimento; (b) "glosa" de O Banquete, de Platão ou de Ulysses, de James Joyce; (c) reescritura distanciada e irônica de uma tradição ocidental-européia; (d) o texto não é um romance em si, mas sim uma "glosa" do gênero; (d) tipo de poema ou um tipo de variação musical.
} 
formar uma história mais próxima do que realmente aconteceu. Pelo contrário, as versões dos participantes da mesma celebração não se complementam e se confirmam, mas se sobrepõem e se contradizem. Essa divergência de vozes aponta para um segundo sentido do título: variação musical que se executa com as mesmas notas. Sendo assim, os participantes do aniversário formam essencialmente três variações dissonantes do evento: Botón, Carlos Tomatis e Pichón Garay. Cada voz surge antes, durante e depois do passeio entre Matemático e Leto. Os tons das vozes - do narrador, dos convidados presentes e dos protagonistas ausentes - são por si só pontos de vista sobre os fatos porque Glosa é principalmente a história de uma conversa sobre outras conversas. As experiências se (re)constroem entre essas vozes que evocam memórias múltiplas.

Alguns dias antes da caminhada, Matemático se encontra com Botón em uma balsa que vai de Santa Fé a Paraná e o último conta os pormenores do aniversário de Washington. Dias depois, quando se encontra com Leto, e felizmente descobre que ele também não participou da festa, Matemático revela ter "la versión completa, en tecnicolor, copia nueva y subtitulada" (2013, p. 30). Entretanto, salienta que o relato que escutou necessita de uma correção contínua porque Botón dá a tudo o que conta um tom fabuloso.

O protagonista em questão avalia com mais clareza a versão do amigo convidado quando revela o seu ponto de vista sobre a personalidade do outro. O narrador externo à narrativa recupera a fala do personagem e relata que, para Matemático, Botón não é uma testemunha ocular confiável de acontecimentos dos quais participa pelo seguinte: fabula porque não suporta a amarga realidade, apresenta os fatos de acordo com quem conversa, tem uma capacidade intelectual limitada e bebe álcool constantemente. Entretanto, Matemático e outros amigos apreciam a sua ingenuidade. O protagonista adota um tom que revela o seu afeto pelo amigo que não é de confiança, mas não por isso menos merecedor da sua amizade, quando passa a falar sobre o caráter de Botón no seguinte trecho: "el timbre del Matemático se vuelve un poco aflautado [...] su tono benévolo y su ritmo cantarino” (2013, p. 215).

Além disso, a tendência à fantasia do convidado em questão dissona com a precisão obsessiva que Matemático deseja alcançar na sua narração da festa a Leto. O último nota que o primeiro desmancha a versão do seu informante desde o início. Ou seja, Matemático sempre parte da versão de Botón para contar a festa, mas a deforma. Por exemplo, quando conta a chegada de um dos convidados da celebração (Noca), o protagonista corrige os "apriorismos estereotipados" do relato evocado por meio do que considera "verdaderos datos empíricos" na 
tentativa de uma rigorosa narração. Entretanto, nessa mesma passagem inicial, Leto separa as duas versões por serem destoantes e escolhe a perspectiva fantasiosa de Botón sobre Noca:

Sin embargo, es la versión de Botón la que, por entre las objeciones sociológicas definitivas aunque desinteresadas del Matemático, Leto adopta y retiene: el Noca mítico buscando, con pericia inmemorial, por el río salvaje, los últimos amarillos, prevalece en desmedro del trashumante de clases a causa de la movilidad social que produce la urbanización creciente de la región litoral (2013, p. 41, grifos nossos).

Sendo assim, o que Botón contou do aniversário em uma entonação fantasiosa se transforma em um relato que Matemático aspira que seja rigoroso na sua inflexão precisa. Entretanto, ele não alcança o seu desejo constante de se ater aos fatos porque não consegue chegar ao que seriam os verdadeiros fatos da festa, mas sim constrói a versão de uma versão afetada significativamente pelo ponto de vista e pelo amor que o personagem nutre com relação aos convidados que contaram a celebração.

Por sua vez, durante a caminhada, os protagonistas se encontram com outro convidado, Tomatis, que conta uma versão cáustica da festa, a qual vê como "un rejuntado de borrachones, pistoleros y carabeteras" (2013, p.113). Leto e Matemático notam que o estado de ânimo desse amigo distorce o seu relato da celebração, segundo assinala o narrador externo à narrativa na seguinte passagem:

[Matemático e Leto pensam que] [...] el estado de ánimo especial de esta mañana induce a Tomatis a presentar los acontecimientos relativos al cumpleaños de Washington de manera distorsionada, apelando sin pudor a la caricatura e incluso a la calumnia en su manera de referir los hechos (2013, p. 114, grifos nossos).

O tom maledicente do amigo que encontram distorce os acontecimentos da festa e leva os dois ausentes a "tomar con pinzas la versión de Tomatis" (2013, p. 114). Essa e a versão anterior se concentram no assunto que os presentes discutiram no aniversário: Botón conta que outro convidado (Basso) chega na festa e avisa que Noca chegará tarde porque o seu cavalo havia tropeçado, deixando claro que essa é uma justificativa do atrasado que, assim como Botón, também tende a fabular. Além de mostrar que o grupo de amigos desconfia do que os próprios membros contam também no plano do "asado" evocado na caminhada, esse fato duvidoso provoca um debate que envolve boa parte dos convidados sobre a possibilidade ou não do tropeço de cavalos e, por extensão, do instinto animal permitir o erro.

Washington Noriega atiça a expectativa dos presentes na festa com seu silêncio 
prolongado sobre esse assunto e, em seguida, rejeita o cavalo como um bom exemplo para a discussão, pois está excessivamente associado ao humano. Por isso, utiliza outro animal para refutar a opinião dos amigos, contando o seguinte: certa noite, o homenageado pelo "asado" estava lendo e percebeu a presença de três mosquitos. Esses agem de distintas maneiras, o que mostra o comportamento incerto dos seres vivos. Sendo assim, essa história é um pretexto para uma reflexão sobre a imprevisibilidade dos animais e uma resposta inesperada para os participantes do debate.

$\mathrm{Na}$ caminhada, Tomatis põe em xeque a intenção da resposta do aniversariante, argumentando que não se pode levá-lo totalmente a sério. Sobre isso, em "Diálogos, risas y tropiezos en Glosa", Daniel Lucero e Nicolás Balderston (2010) ressaltam que a versão de Tomatis introduz no discurso de Washington a ambiguidade do humor porque é difícil saber quando o aniversariante fala na brincadeira ou seriamente.

Ainda de acordo com os críticos acima, para o novo caminhante, a refutação do protagonista da festa sobre o absurdo comportamento de mosquitos pode ter sido um meio de ridicularizar os amigos que discutiam apaixonadamente sobre cavalos e a possibilidade do instinto animal permitir o tropeço. Sendo assim, o risco da zombaria atiça as dúvidas dos interlocutores, o que multiplica as possibilidades de sentido do discurso, assim como acontece com a tentativa de (re)construção da festa na caminhada.

Concordamos que a suspeita se acentua porque a ameaça da burla parece incidir sobre os protagonistas, que também conversam em torno do que se discutiu na festa: Matemático e Leto devem levar a sério ou na brincadeira o que dizem o aniversariante e os outros convidados? Entretanto, Lucero e Balderston (2010) não levam em consideração o efeito do desencontro de distintos estados de ânimo e tons nas vozes dos ausentes e dos presentes que tentam recuperar a celebração, o que também torna o que os outros amigos dizem em incerto e, por conseguinte, passível de desconfiança. Por exemplo, depois que Tomatis se despede, Matemático refuta ponto por ponto as suas afirmações envenenadas, reconhecendo que o primeiro é capaz do abjeto e do sublime e mostra sua preferência pela versão de Botón. Além do relato desse parecer mais verossímil, o "incidente Tomatis" é, de acordo com o narrador que "traduz" a percepção dos protagonistas, uma "masa blanda y oscura que acaba de enchastrar la mañana [solar do passeio] con sus salpicaduras pegajosas" (2013, p. 154). Ou seja, os protagonistas devem recusar o que esse amigo deprimido disse para que eles e a caminhada não se contaminem pelo seu humor negro. 
A terceira voz surge na prolepse do romance, momento em que o narrador externo à narrativa conta o que acontecerá com os personagens em um futuro que se localiza anos depois do fim da caminhada, centro argumentativo e presente de Glosa. Nesse futuro, um outro passeio ocorre pelas ruas de Paris entre Matemático e Pichón Garay, outro participante do aniversário que havia ocorrido muitos anos atrás. Nessa nova caminhada, os dois aludem à intervenção do aniversariante no debate, mencionando "los mosquitos de Washington". A rede de amigos usa essa expressão para se referir a algo de existência duvidosa. Os dois a utilizam porque duvidam que as autoridades francesas farão o que prometeram, tomar alguma atitude em relação às denúncias dos efeitos da última ditadura militar argentina ${ }^{4}$, realizadas por uma comissão de exilados que incluía Matemático e Pichón.

Os caminhantes desse passeio evocam novamente o aniversário quando usam a expressão acima mencionada. O mais interessante é que Pichón está convicto da presença de Matemático na festa, algo que o último corrige reforçando a sua ausência no evento. Essa afirmação, por parte de Pichón, e essa negação de ter participado, por parte de Matemático, desafinam a nitidez da lembrança falsa do primeiro, demonstrando também o seu alheamento aos fatos que vivenciou. Ainda assim, resiste a tirar Matemático de suas recordações: "Pichón se había visto obligado, no sin esfuerzo, y sin duda sin convicción, y temporariamente, a sacarlo [a Matemático] de su recuerdo, tan fresco, nítido y ordenado, como si le viniese del día anterior” (2013, p. 138). Sendo assim, Pichón assegura a existência de Matemático no grupo quando o inclui na sua versão da celebração.

As versões da festa são um fracasso no resgate do aniversário na sua inteireza e confiabilidade, mas produzem lembranças que multiplicam as possibilidades do relato de um mesmo acontecimento justamente por serem fragmentárias e incertas. Isso se dá porque a relação que se estabelece entre os personagens e entre narrador e personagens não tem como base o consenso, o apaziguamento e a homogeneidade, mas sim o dissenso, o conflito e a heterogeneidade ${ }^{5}$.

A proliferação das versões reflete os encontros e desencontros entre os amigos. Como se viu, o tom fantasioso de Botón vai de encontro com o tom cientifista de Matemático que,

\footnotetext{
${ }^{4}$ Como veremos mais adiante, a prolepse do romance é política, uma vez que o futuro da rede de amigos está principalmente marcado pelas consequências terríveis da última ditadura militar argentina, como o exílio, no caso de Matemático, e o suicídio do futuro guerrilheiro Leto.

${ }_{5}^{5}$ Maurice Blanchot (2002) reflete sobre esse tipo de comunidade conflitiva em La comunidad inconfesable. Dialogaremos com esse filósofo mais adiante.
} 
por sua vez, também confronta o tom maledicente de Tomatis e o tom convicto de Pichón. E todos esses modos de narrar divergem na recepção de Leto, que poderia ser vista com um tom ingênuo porque ele não conhece nada ou pouco do grupo de amigos. Cada tom, como dissemos no início, é um ponto de vista diverso acerca de um mesmo acontecimento.

Piglia (2010) também alude a outro tipo de amizade: a relação afetiva entre um velho sábio e jovens intelectuais, a qual alguns críticos da obra saeriana identificam como uma alusão a relação que o jovem Juan José Saer mantinha com o mais velho poeta Juan L. Ortiz ${ }^{6}$. De acordo com Lucero e Balderston (2010), o aniversariante pode ser comparado com o filósofo Sócrates dos diálogos platônicos ${ }^{7}$ porque ambos não ensinam aos seus interlocutores um conhecimento específico, mas sim um comportamento atento e desconfiado em relação ao discurso. No caso do romance em análise, Washington possui um tom ambíguo marcado pelo seu humor e leva a discussão central da festa a um plano impensado, substituindo certezas por dúvidas. Ou seja, o personagem enfatiza a potência do pensamento, a qual Agamben (2017) explica ser da seguinte maneira em $O$ uso dos Corpos: "Pensar não significa simplesmente ser afetado por essa ou aquela coisa, por esse ou aquele conteúdo de pensamento em ato, mas [...] fazer experiência em cada coisa pensada, de uma pura potência de pensar" (p. 237).

Nesta primeira parte, veremos como a potência também incide sobre o modo como Matemático e Leto apreciam as outras versões, como apontamos mais acima.

Esse grupo de amigos cultiva um comportamento dubitativo e crítico, mas não menos afetivo, em relação aos seus membros porque discordar é muito mais produtivo e divertido que concordar. Portanto, a amizade é estruturante em Glosa, não por ser somente o tipo de afeto privilegiado nas relações entre os personagens, mas porque as vozes dissonantes dos amigos compõem o centro da trama: lembranças e experiências, alheias ou próprias, duvidosas e singulares.

Sendo assim, Glosa é uma versão negativa de O Banquete, diálogo platônico e modelo

\footnotetext{
6 Em "El lugar de Saer", María Teresa Gramuglio (2010) sustenta que o escritor se inspirou em alguns de seus amigos intelectuais e artistas santafesinos para construir muitos dos seus personagens. Uma pessoa central de tal grupo foi Juan L. Ortiz (1896-1978), amigo, poeta e grande influência na literatura de Juan José Saer.

Em "Juanele", prólogo dedicado às obras completas do poeta, Saer constrói uma filiação poética com ele e descreve como esse grupo de Santa Fe se reunia em encontros semelhantes à festa em homenagem a Washington Noriega, narrada em Glosa: reuniões na casa de Juanele, na casa de Saer ou outro amigo. Em tais encontros, os amigos intelectuais conversavam durante horas ao redor de um "asado".

${ }^{7} \mathrm{Na}$ edição genética de Glosa/El entenado (2010), Julio Premat comenta na nota 33 como Saer se aproveita da estrutura de um diálogo platônico ( $O$ Banquete) para a trama central de Glosa e como o personagem Washington seria o seu Sócrates. De acordo com a introdução de uma recente edição de O Banquete (2011), as perguntas de Sócrates despertam nos seus interlocutores o questionamento das suas convicções e, por conseguinte, o desejo de saber mais.
} 
estrutural do romance. Em uma caminhada, Apolodoro conta a Glauco o debate que aconteceu num banquete oferecido por Agatão, no segundo dia de comemorações por sua vitória numa competição de tragédias. Como Leto e Matemático, nenhum dos dois esteve na festa que ocorrera muitos anos atrás. Entretanto, Apolodoro se vale da versão de Aristodemo, reforçada e confirmada pelo mestre e objeto do amor de ambos, Sócrates, protagonista do debate, assim como de outros diálogos platônicos. Mas, ao contrário de Glosa, as versões se reforçam e não se contradizem.

Além disso, o amor subserviente e fiel que Apolodoro e Aristodemo nutrem pelo mestre Sócrates garante a exatidão da narração dessa festa grega. Na introdução de uma recente edição de $O$ Banquete ${ }^{8}$, Victor Sales Pinheiro (2011) defende que nesse e em outros diálogos, "a memória erótico-mimética é a tentativa de resistir ao tempo que afasta, dispersa e transforma o ocorrido, conservando-o intacto pela sua repetição mnemônica constante" (p. $34)$.

No caso de Glosa, pelo contrário, as versões da festa admitem a dispersão e transformação do ocorrido justamente pela amizade que Matemático e Leto nutrem pelos participantes que narraram a festa: o que os amigos contam é passível de uma atitude desconfiada pelos motivos apresentados acima. Além disso, na sua tese Glosas e silêncio em Juan José Saer, Antônio D. Pereira Jr. (2006) aponta que o romance hiper-explicita a constituição das versões por meio da exasperação dos verbos dicendi ${ }^{9}$ e põe em primeiro plano narrativo a caminhada que (re)constrói o aniversário. No Banquete, Apolodoro menciona só em alguns momentos que a versão que conta é a de Aristodemo e é a festa que está em primeiro plano.

Entretanto, em um trecho do modelo glosado pelo romance, Apolodoro confessa a fragilidade e seletividade da sua memória: “[...] de tudo o que [...] foi dito, Aristodemo não se recordava muito bem, como eu, da mesma forma, não me lembro agora, com minúcias, do que ele me contou" (2011, p. 89). Sendo assim, Glosa amplia o que já é negativo no Banquete: dúvida da exatidão narrativo-mimética de Apolodoro por causa da fragilidade da

\footnotetext{
${ }^{8}$ PLATÃO. O Banquete. 3. ed. Belém: ed. ufpa, 2011.

${ }^{9}$ De fato, Glosa está repleta desses verbos, como em: "Según Botón, y, desde luego, según el Matemático [...]" (2013, p. 121); “ dice el Matemático que le dijo Botón que dijo Tomatis” (2013, p. 47). Nos dois exemplos anteriores, se explicita que o que os personagens dizem também se constitui do que os outros disseram anteriormente.
} 
memória e, por conseguinte, da ficcionalidade do diálogo platônico. Novamente de acordo com Pinheiro (2011):

Neutralizando a certeza da base histórica, as sucessivas intermediações discursivas sugerem que nenhuma história pode ser contida no nivel mimético. [...] Apolodoro confessa a fragilidade e a seletividade de sua memória e a consequente precariedade do relato intermediado por Aristodemo. História ficcional de Apolodoro, $O$ Banquete é [...] uma ficção histórica de dimensão mítica (lendária). Distanciando-se dos Apolodoros e Aristodemos, a forma que Platão encontrou ao ser fiel a Sócrates é reinventando-o e amando-o (2011, p. 35, grifo nosso).

Sendo assim, diferentes formas de amar criam diferentes formas de contar uma experiência. Por um lado, a fidelidade dos amigos de Sócrates minimiza, mas não exclui, as deformações da memória. Por outro, a desconfiança entre os amigos de Glosa maximiza e multiplica as transformações da memória.

\subsection{Potências negativas}

A excessiva desconfiança posta em todas as versões da festa torna-a inacessível por completo porque as lembranças divergentes a transformam e a fragmentam em pontos de vista. Entretanto, esse provável fracasso da recuperação de um acontecimento passado é o motor do argumento central justamente pela dúvida em relação à (in)capacidade de se apreender a experiência própria ou alheia, sem mediações.

A crítica especializada na obra saeriana ${ }^{10}$ observa na sua narrativa uma constante interrogação sobre as possibilidades da percepção subjetiva apreender o real. Como se viu no item anterior, essa visão de mundo ligada a uma subjetividade desestabiliza o experimentado devido a sua constante reformulação pelas consciências instáveis e desconfiadas dos personagens.

Assim como Walter Benjamin (2000) em "O narrador", Theodor Adorno (2003) admite em "A posição do narrador no romance contemporâneo" a impossibilidade de narrar devido à perda de sentido da experiência no período entre guerras pela dificuldade ou incapacidade de se compartilhar uma experiência traumática. Entretanto, também defende que a narrativa contemporânea faz dessa impossibilidade o seu objeto e insiste na sua narração, instaurando, dessa maneira, um paradoxo fundamental.

10 Gramuglio (1986), Dalmaroni e Merbilhaá (1999) e Abbate (2010) exploram com mais detimento a experiência sob suspeita na obra saeriana como um todo. 
Saer participa dessa visão negativista da narrativa porque demonstra uma desconfiança irredutível em relação às possibilidades da arte representar o real, a experiência e a memória através da percepção do indivíduo. Em vista disso, a atitude dubitativa dos amigos leva os relatos da festa ao terreno da conjectura, como esclarece o narrador externo à narrativa:

\begin{abstract}
Pero entendámonos bien: como se supone que estamos de acuerdo en que todo esto [...] es más o menos, que lo que parece claro y preciso pertenece al orden de la conjetura, casi de la invención, que la mayor parte del tiempo la evidencia se enciende y se apaga rápido más allá, o más acá [...] de lo que llaman palabras [...] todo esto es más o menos y [...] después de todo, iqué más da! (2013, p. 201).
\end{abstract}

O caráter conjectural da narração tem relação com a visão do escritor sobre a literatura. De acordo com o seu ensaio "El concepto de ficción", , a ficção é uma antropologia especulativa sobre as possíveis maneiras de ser do homem, do mundo e da sociedade. Sendo assim, a especulação é o motor de sua criação porque leva a narrativa saeriana para o terreno do inverificável e, por conseguinte, do indefinido, do que pode ser de múltiplas maneiras.

Além do mais, quando o narrador usa a expressão “iqué más da!”, demonstra não dar muita importância para a correspondência entre representação e referente, apesar da sua constante tentativa de narrar detalhada e obsessivamente o que acontece na caminhada, na conversa que reconstrói o aniversário e nas consciências dos protagonistas. Tais atitudes são conflituosas porque o narrador sabe que é impossível a total correlação entre narração e experiência, mas nem por isso deixará de tentar contá-la.

Em “"Un azar convertido en don’. Juan José Saer y el relato de la percepción”, Miguel Dalmaroni e Margarita Merbhilaá (1999) sustentam que a impossibilidade de representar o mundo não tem como resultado um abandono do relato, mas sim estabelece uma tensão entre a negação da representação realista e uma produtividade narrativa que surge dessa negatividade através da percepção dos sujeitos na narrativa saeriana. O relato continua a nascer da possibilidade da experiência, do próprio sujeito que narra ou de outro. Entretanto, a memória e sua narração potencialmente duvidosas mostram ou mantêm a opacidade da experiência, ideia que Garramuño (2012) desenvolve em A experiência opaca: literatura e desencanto, livro em que se debruça sobre a literatura de escritores argentinos e brasileiros a partir dos anos 80 , entre eles, Juan José Saer. Nesse texto e em outro artigo ${ }^{12}$, a crítica defende

\footnotetext{
${ }^{11}$ SAER, Juan José. “El concepto de ficción”. In: El concepto de ficción. Buenos Aires: Ariel, 1997.

${ }^{12}$ GARRAMUÑO, Florencia. "Las ruinas y el fragmento. Experiencia y narración, en El Entenado y Glosa". In: SAER, Juan José. Glosa/El entenado. Edición crítica. Julio Premat (coord.) Poitiers, Córdoba: CRLA, Alción,
} 
que Glosa é um romance que se reapropria desconfiadamente do experimentado e recria no seu argumento a tensão entre experiência e narração, uma maneira de se aproximar de uma realidade confusa e incognoscível em si mesma.

Tal opacidade é uma forma de perceber o mundo. Como se viu no item anterior, o romance adianta que não há uma relação de transparência entre a narração e o mundo desde o título. A interpretação é necessária para dar conta desta realidade que, enquanto versão, é sempre fragmentária, insuficiente e deformadora. Por isso, a narração também é uma "experiência opaca", complexa e difícil em si mesma, mas continua sendo o único meio de transmitir e tornar significativo um acontecimento da vida humana, por mais disparidades, transformações, defeitos de percepção e limites que surgem.

A relação marcada pela desconfiança em relação ao discurso do outro ocorre também no modo como o narrador externo à narrativa se relaciona com o que narra. Assim como os personagens devem duvidar do sentido e das maneiras de dizer dos relatos dos amigos, o narrador também possui um tom sempre desconfiado e incerto em relação ao que conta, exagerando na sua atenção às disparidades entre o que os personagens falam e pensam, escutam e entendem, sabem e ignoram. Isso aguça o ouvido do leitor, que suspende a sua credulidade em um narrador que domina o que está narrando ${ }^{13}$. O próprio início do romance coloca a narração em uma indeterminação cronológica: "Es, si se quiere, octubre, octubre o noviembre, del sesenta o del sesenta y uno, octubre tal vez, el catorce o el dieciséis, o el veintidós o el veintitrés tal vez, el veintitrés de octubre de mil novecientos sesenta y uno pongamos—qué más da" (2013, p. 13).

O constante uso da expressão "más o menos" ao longo de Glosa explicita a presença da incerteza na percepção do narrador externo à narrativa e dos personagens e na capacidade da narração ser um meio de conhecer o passado. Outro exemplo é o constante uso da expressão oral "no?" que evoca no discurso do narrador uma cumplicidade com o leitor por meio do convite a uma interrogação negativa atenta ao que o narrador e personagens contam e pensam. Por isso, concordamos quando Lucero e Balderston (2010) propõem que o narrador não tem o objetivo de esclarecer, mas formular perguntas que desconcertem o leitor por meio

2010.

${ }^{13}$ Cf. BASTOS, María Luisa. "Eficacias del verosímil no realista. Dos novelas de Juan José Saer". In: SAER, Juan José. Glosa/El Entenado. Edición crítica. Julio Premat (coord.) Poitiers, Córdoba: CRLA, Alción, 2010. Nesse texto, a autora defende que, paradoxalmente, o narrador de Glosa garante a sua credibilidade explicitando o seu não-domínio do que narra. 
de um inesgotável questionamento e uma reformulação da narração. Sendo assim, o narrador estabelece uma relação de cumplicidade com o leitor na qual ensina-o a estar sempre atento aos "tropeços", limites e dificuldades do relato dele próprio e das outras vozes que circulam no romance.

Em um ensaio chamado "La selva espesa de lo real", Juan José Saer (1997) enumera três capacidades indispensáveis do narrador atual: disponibilidade, incerteza e abandono. $\mathrm{O}$ narrador tem disponibilidade para a narração, abandona todas as certezas e admite todas as incertezas, por mais que as mesmas levem ao fracasso e ao não encerramento do relato. Tais capacidades entram em consonância com as reflexões de Adorno (2003) sobre a posição do narrador, pois a recolha na subjetividade (a percepção) coloca em primeiro plano a dificuldade de compreender a realidade, o que Alberto Giordano (2010) chama de "efecto de irreal" na prosa saeriana em um artigo de mesmo nome. Esse suspende todas as certezas e mostra o lado do real que se esconde, mostrando a experiência da contorção e da confusão.

O estabelecimento de uma zona fronteiriça e opaca para a recepção dos relatos da festa permite que Leto - e o leitor junto com ele ${ }^{14}$ - transforme o que pensa sobre Matemático, sobre os convidados e acrescente elementos ao lugar onde transcorre o aniversário. Se a dúvida que marca as múltiplas versões conduz Matemático a escolher a mais verossímil para construir a sua própria narração da festa, a recepção de Leto opta por um caminho diferente. Como mencionamos, o último prefere a versão fabulosa de Botón, demonstrando que a tendência à fantasia também incide sobre a recepção da narração rigorosa de Matemático. Esse, por exemplo, se vale da versão de Botón e do seu conhecimento prévio para descrever para Leto o espaço onde ocorre o aniversário evocado na passagem que segue. O narrador externo à narrativa nos mostra como o último imagina um lugar onde nunca esteve:

Y el lugar en el que esa quinta se levanta [...] abarca una extensión material que excede por lejos su experiencia, es un punto aproximativo, un poco fabuloso, que Leto ubica, sin saber por qué ni tampoco preguntárselo, en una zona fronteriza entre su experiencia y los muchos fragmentos puramente imaginarios que incluye la palabra Colastiné y que él nunca ha visitado (2013, p. 63, grifo nosso).

Tal recepção reflete o modo como o romancista enxerga os efeitos do trabalho narrativo. Em uma entrevista de 1986, ano de publicação de Glosa, compilada em um recente

\footnotetext{
${ }^{14} \mathrm{O}$ nome Leto é muito parecido com a palavra "leitor", em português, ou "lector", em espanhol, possuindo quatro letras - "l", "e", "t", "o" - na mesma ordem.
} 
livro ${ }^{15}$, o escritor declara o seguinte:

el trabajo narrativo consiste en transformar nuestras experiencias y nuestros recuerdos en visiones, en formas que produzcan en el lector imágenes vívidas que lo alcancen no solamente en su inteligencia sino también en sus emociones, y en las cuales se reconozca no como simple voyeur sino como sujeto de esas visiones que el escritor le propone (SAER, 2016, p. 63, grifos nossos).

A especulação de Leto sobre a festa não é completamente fabulosa, nem completamente empírica, mas está "en una zona fronteriza entre su experiencia y los muchos fragmentos puramente imaginarios" porque o protagonista é um recém-chegado à cidade e ao círculo de amigos. Por isso, ele desconhece os pontos de encontro do grupo e a maioria dos membros da rede de amigos, o que inclui os presentes no aniversário e o próprio Matemático. Dessa maneira, Leto tem que se valer dos relatos de Matemático e Tomatis, do que imagina e de experiências vividas empiricamente, mas alheias aos fatos contados, para formar uma percepção do evento, dos convidados e do outro protagonista do romance.

Além do mais, esse entrelugar de memórias - próprias e alheias - e imaginação possibilita que o ouvinte não aceite as refutações de Matemático em relação à versão venenosa de Tomatis e amalgame ambas, apesar de contraditórias. Isto é, na consciência do receptor as versões não se excluem, mas se mantém como possíveis na recepção, uma vez que o leitor e o personagem também têm acesso à versão do convidado em questão, com ou sem a mediação do outro protagonista. Tal possibilidade é o que Agamben (2015) chama de potencial da criação em "Bartleby, ou da contingência".

Nesse texto, o filósofo analisa a personagem do conto "Bartleby, o escrevente: uma história de Wall Street", de Herman Melville. Partindo majoritariamente das reflexões de Aristóteles, sustenta que a principal potência humana é a "potência de não" passar ao ato: a ambivalência de ser e não ser, de fazer e não fazer. O criador (artista) torna essa impotência uma experiência literária, colocando o sentido da verdade factual em dúvida e subtraindo os princípios de contradição, revelando um ser potencial que possibilita a coexistência do "poder ser" e do "poder não ser".

Partindo de Walter Benjamin, Agamben (2015) sustenta que o personagem literário ao qual se debruça pode fazer com que suas recordações façam do inconcluso um concluído e do

\footnotetext{
${ }^{15}$ SAER, Juan José;SAAVEDRA, Guillermo. "El arte de narrar la incertidumbre”. In: PRIETO, Martín (comp.) Juan José Saer: una forma más real que la del mundo. Buenos Aires, 2016.
} 
concluído um inconcluso, de modo que a recordação não é nem o que ocorreu, nem o que não ocorreu, mas o seu potenciamento. Nesse sentido, assim como Bartleby, os convidados e ausentes da festa em Glosa restituem potência ao passado evocado, observando sempre a possibilidade do acontecido e do não acontecido. Como a literatura antropológico-especulativa saeriana, os protagonistas - e em especial, Leto — não abrem mão do potencial de criação e transformação das versões, não apesar, mas justamente pela desconfiança do que se conta sobre a celebração entre amigos. Sendo assim, o potencial da dúvida propicia uma especulação produtiva sobre as possibilidades ou impossibilidades múltiplas da narração recuperar e representar o passado, e não uma negação que a paralise.

Ainda de acordo com Agamben (2015), a "potência de não" diz respeito ao poder em si, e não ao querer ser/fazer ou não ser/fazer. No romance em questão, o narrador externo à narrativa sempre põe em dúvida a capacidade de Matemático em procurar a verdade dos fatos por meio de versões nada confiáveis, por mais que o último se valha do poder de conhecer o lugar e as pessoas presentes na festa para tornar a sua narração mais detalhada e verossímil para o seu ouvinte. Matemático quer, mas não pode, não consegue. A interpretação, um dos sentidos para o título Glosa, relativiza o percebido por meio de consciências e de vozes parciais e fragmentárias. A narração que se quer como um "versión completa, en tecnicolor, copia nueva y subtitulada" é uma versão incompleta e opaca. Além do mais, a recepção de Leto também transforma consideravelmente a narração que escuta em incerta, em algo que desconhece. Esse protagonista e o narrador externo à narrativa assumem a incerteza e a impotência de uma narração que busque a verdade dos fatos.

As versões como "potências de não" mostram menos a dificuldade de contar o que se viveu diretamente ou através do relato do que uma tensão entre o constante desejo do narrador e dos personagens em recuperar o experimentado confiável, completa e diretamente, e o acesso indireto por meio de memórias fragmentárias, duvidosas e díspares que os pontos de vista da rede de amigos (re)constroem. Não é somente Matemático que glosa versões da festa em que nunca esteve, mas também o narrador externo à narrativa é o glosador de um saber que nunca se encerra e se confirma.

Para Julio Premat (2002) em La dicha de Saturno. Escritura y melancolía en la obra de Juan José Saer, os objetivos da literatura do escritor são: 
contrario, sino de abrir en ella una fisura en donde lo imaginado tenga la misma consistencia, la misma trascendencia, el mismo valor que lo vivido (p. 295).

No seguinte ponto, falaremos sobre como essas fissuras são centrais nas experiências e memórias dos personagens.

\subsection{Experiências estético-narrativas}

Os relatos de lembranças são (re)construções de percepções dos personagens desde o presente da narração ${ }^{16}$ que atualiza e, principalmente, transforma o vivido em versões. $O$ registro subjetivo e fragmentário da experiência desnaturaliza as perspectivas do passado, uma vez que lembrar para narrar é uma tarefa difícil. De acordo com o próprio Juan José Saer (2010) em um texto que fala sobre as razões da sua obra como um todo ${ }^{17}$ : "el mundo es dificil de percibir. La percepción es difícil de comunicar. Lo subjetivo es inverificable. [...] Experiencia y memoria son inseparables" (p. 320).

Nesse sentido, de acordo com Miguel Dalmaroni e Margarita Merbilhaá (1999), em Glosa e na narrativa saeriana como um todo não existem memórias involuntárias, mas percepções involuntárias do experimentado. Lembrar-se pressupõe um esforço por parte do sujeito, mas o resultado é involuntário porque se produz um encontro inesperado entre percepção subjetiva e mundo, por mais incerto e fugaz que esse encontro seja. O exercício da memória é de responsabilidade do indivíduo e, por esse motivo, é instável e fugidia.

Experiência e memória são inseparáveis porque a primeira se conserva e, por conseguinte, existe por causa da última. Entretanto, como se viu até agora, as duas não são iguais e, além disso, estão em constante tensão. As memórias individuais e percepções singulares dos personagens transformam os acontecimentos vividos empiricamente e/ou por meio do relato. Os comentários/glosas da festa, ou de qualquer experiência, não recuperam um passado, mas partem de lembranças alheias para construir lembranças novas e individuais.

O relato é possível e necessário pela exclusão da festa, porque não estar possibilita a reconstrução ficcional da memória. A ausência marginaliza fugaz e superficialmente Leto e Matemático do círculo de amigos e os faz desaparecer do relato da festa. Em vista disso, a

\footnotetext{
${ }^{16}$ Cf. SAER, Juan José. "Zama" in El concepto de ficción. Buenos Aires: Ariel, 1997.

${ }^{17}$ SAER, Juan José. "Razones" in Crítica cultural, Santa Catarina, v. 5, n. 2, p. 315-324, 2010. Número especial. Disponível em: < http://www.portaldeperiodicos.unisul.br/index.php/Critica_Cultural/article/view/705/660>
} 
única forma dos protagonistas acessarem e participarem do que aconteceu e se discutiu no "asado" é por meio do intercâmbio de relatos fragmentários e duvidosos. Por isso, Dalmaroni e Merbhilaá (1999) apontam um paradoxo na narrativa saeriana como um todo: os pontos de vista sob suspeita são a única forma dos personagens se ligarem ao mundo. Como se observou, esse acesso não está dado, mas se constrói ao longo da caminhada compartilhada entre os protagonistas. Ou seja, as versões mostram uma história sempre mutante que se compõe de lembranças parasitárias e falsas "de un día de fin de invierno que no está inscripto en la experiencia [vivida] pero que sobresale, intenso, en la memoria" (2013, p. 85). Sendo assim, a narrativa é também uma experiência que pode se transformar na memória dos ausentes. Chamemos isso de experiência estético-narrativa.

A explicitação da não necessidade de viver empiricamente o que se lembra e se narra está belamente dito também nos versos do poema "El arte de narrar", também do autor de Glosa: o relato é uma justaposição de "recuerdos falsos para memorias verdaderas". Em uma entrevista ${ }^{18}$ à revista Letras Libres, o escritor dá uma interpretação para esse verso: os leitores têm lembranças falsas que nunca existiram ou viveram, mas constituem uma presença constante nas suas vidas, o que amplia a noção de experiência para além do empírico.

A ficção é uma realidade ${ }^{19}$ porque, paradoxalmente, a única forma de acessá-la é por meio de construções imaginárias. Ninguém sabe de fato como são os acontecimentos, porque não são independentes de uma mediação, percepção e imaginação singulares dos personagens. As interpretações da festa complexificam um encontro cotidiano e simples entre amigos porque expõem limites e diferentes visões. Portanto, o relato é uma forma de produção perceptiva que manteria, transformando-a, uma experiência importante, um modo de estar no mundo e se relacionar.

A experiência narrativa é verdadeira porque é vivida ao longo da caminhada e própria porque não parece ser possível que os personagens possam escapar dos seus pontos de vista pessoais e muito menos consigam retirar as mediações e acessar diretamente o que ocorreu no evento. Por exemplo, a narração da festa por parte de Matemático, já uma modificação do relato da lembrança de Botón e uma refutação da versão de Tomatis, se transforma na

\footnotetext{
18 SAER, Juan José; VALLE, Gustavo. "Una incertidumbre elocuente (entrevista con Juan José Saer)". Letras libres, Madrid, $\quad$ n. $09, \quad$ jun. $2002 . \quad$ Disponível em: $<$ http://www.letraslibres.com/mexico-espana/la-incertidumbre-elocuenteentrevista-juan-jose-saer $>$. Acesso em: 30 nov. 2016.

${ }^{19}$ Cf. SAER, Juan José. "Sobre Onetti y la vida breve" in Trabajos. Buenos Aires: Seix Barral, 2011.
} 
recepção de Leto porque as imagens que se formam na consciência de cada um dos protagonistas é intransmissível ou irrepresentável por ser o que lhes é mais íntimo. Sobre isso, César Aira (2007) defende em "La intimidad" que o foro interior do indivíduo resiste a comunicar os seus afetos, sentimentos e desejos, no sentido da linguagem se articular menos por ser a parcela mais singular do sujeito.

Na seguinte passagem de Glosa, o narrador externo à narrativa conta que Matemático imagina a festa e os convidados, mas as imagens que constrói são privadas e, por isso, pertencem ao intransmissível de suas representações, mais particulares que uma impressão digital: “[...] esas imágenes aparentemente arbitrarias y sin sentido que, sin embargo, [...] mostrarían su especificidad personal, más todavía que sus impresiones digitales o los rasgos de su cara." (2013, p. 214-215, grifos nossos).

A particularidade da imaginação da festa se mostra mais interessante quando o narrador externo à narrativa se movimenta pelas consciências dos caminhantes. No fragmento abaixo, os protagonistas constroem diferentemente a aparência física de Botón:

\footnotetext{
Los dos se lo representan: el Matemático rubio, crespo, con el bigotito rubio [...], los ojos casi transparentes a causa del azul tan claro, recién bañado y peinado, [...], y Leto morocho, impreciso, la piel oscura, picada de viruelas, con el pelo bien lacio y un poco rebelde, de una dureza casi metálica, sin que Leto sepa, ni se haya planteado nunca el problema, ya que no lo ha visto nunca, por qué encadenamiento de asociaciones desconocidas que evoca la palabra Botón, sumadas a las características que atribuyen a su titular, se lo imagina de esa manera (2013,p. 64).
}

Esses movimentos entre as consciências dos personagens mostram que a voz narradora externa à narrativa é como uma caixa de ressonância das outras vozes que circulam em Glosa, uma vez que o narrador foca em determinadas percepções. Como se viu, essas se manifestam por meio de perspectivas duvidosas do mundo e dos outros, fazendo com que a narração avance sobre o ato de perceber. Por isso, a multiplicidade das percepções do passado e do presente se manifesta em um foco narrativo multisseletivo ${ }^{20}$. Esse é a representação de um mesmo aspecto da realidade a partir de ângulos de visão diversos por meio da mente dos personagens - pensamentos, lembranças, impressões e sentimentos - a medida que ocorrem.

A adoção desse foco favorece a predominância do discurso indireto livre que, de acordo com Wood (2012) em Como funciona a ficção, permite que o leitor veja por meio dos olhos e da linguagem dos personagens e dos narradores simultânea e/ou confusamente. O

\footnotetext{
${ }^{20}$ Cf. LEITE, Lígia Chiappini M. O foco narrativo. 11 ed. São Paulo: Ática, 2007.
} 
narrador é, ao mesmo tempo, onisciente e parcial. Em Glosa, penetra nas emoções e nas percepções dos personagens, transformando em discurso aquilo que eles mesmos não põem em palavras e seguindo com uma precisão hiperbólica as cadeias de enunciação. Entretanto, não conhece diretamente os fatos da festa, uma vez que se atém principalmente à consciência dos protagonistas que estavam ausentes. Por isso, os relatos que expressam as vidas interiores dos personagens e as lembranças alheias e próprias da festa possuem um sentido pessoal e intransferível. As versões se repetem e disseminam uma trama difusa e fragmentada em uma espiral de discursos referidos e ressignificados em interpretações/glosas não-intercambiáveis.

A partir dessa perspectiva múltipla, diversos tons e sentidos surgem no processo da narração e não lhe são preexistentes: não existe uma versão mais verdadeira do vivido ou uma perspectiva mais confiável, mas versões justapostas da realidade e postas sob o signo da dúvida pelos personagens e narrador. Portanto, não existe mundo comum em Glosa. Cada vivência e lembrança - alheias ou próprias - são únicas para cada um, a cada tempo, no presente, no passado ou no futuro. O passado quando transmitido passa a ter um sentido próprio àquele que o transmite e àquele que o recebe.

A inexistência de um mundo comum não quer dizer que não exista uma relação com o outro. Como se viu até agora, as lembranças se negam à compreensão completa, à representação confiável dos fatos e à harmonia de pontos de vista, mas não eludem o intercâmbio através do relato. Por um lado, em "La historia en las ficciones de Juan José Saer", Florencia Abbate (2010) ressalta que a experiência e a lembrança não são modos de conhecimento fiáveis, pois ambas não dão conta de mostrar como um momento factual realmente foi. Por outro, menciona os seus efeitos no âmbito do intercâmbio de experiências.

O segundo ponto é o mais interessante para o que se analisará agora. Entretanto, a autora simplifica a leitura do poder de compartilhamento da memória em Glosa provavelmente porque esse ponto não é o seu foco de análise. Ela dá como exemplo de união a caminhada de Pichón e Matemático porque possuem um passado comum, a força da experiência e da lembrança. Por sua vez, essa mesma força separaria completamente Leto e Matemático. Como ilustração, cita o fragmento abaixo que alude à caminhada:

la narración [...] se vuelve, poco a poco palabras sueltas, ruido carente de sentido, rumor lejano, como si, a pesar del ritmo idéntico de la marcha y de los brazos que casi se rozan, caminasen por espacios disociados, probando en qué medida un recuerdo puede separar a dos hombres (2013, p. 42). 
Lendo esse trecho, se poderia presumir que os dois personagens, apesar de caminharem juntos, estão completamente perdidos na sua própria "ciénega de la memoria". Mas, como se mostrou, não é isso que acontece no romance em questão. Por exemplo, na passagem que segue imediatamente depois ao fragmento acima citado, o narrador externo à narrativa nos conta que o Leto, perdido durante um curto momento nos seus próprios pensamentos, volta novamente o seu foco de atenção à narração do aniversário de Washington Noriega:

el llamado [dos pensamientos íntimos de Leto] se desvanece, [...] de modo que la expresión de Leto se vuelve otra vez sonriente y atenta y las palabras [a narração] del Matemático salen del horizonte de ruido y continúan llenando de imágenes, no siempre adecuadas, su cabeza (2013, p. 42).

A narração é uma forma dos protagonistas não estarem completamente ausentes, na festa e na caminhada, no sentido de ambos participarem da perpetuação desse evento nas suas memórias e na memória dos outros, como no caso de Matemático na rememoração de Pichón Garay da festa no futuro do argumento central de Glosa. Portanto, ao mesmo tempo que a exclusão produz um mal-estar nos dois por se sentirem ameaçados por tal marginalização, essa mesma sensação suscita a experiência narrativa da conversa sobre o aniversário.

Além disso, Matemático, narrador-personagem, necessita de um ouvinte/leitor para que a lembrança parasita se exteriorize em uma narração e a experiência transmitida ganhe sentidos novos e próprios ao ser relatada a alguém. Sendo assim, em Glosa se põe em cena uma relação que Walter Benjamin no clássico ensaio "O narrador" considerava perdida: a narrativa como um processo compartilhado no qual a relação entre narrador e ouvinte permite que o primeiro insira a experiência pessoal transmitida ou experimentada por outras pessoas, suscitando a construção de um relato de experiências próprias e alheias. A necessidade do outro suscita a criação de laços afetivos. Narrar é construir uma comunidade entre aquele que narra e seus ouvintes.

No romance em questão, o ouvinte (Leto) contribui pouco na narração do aniversário, uma vez que o poder de contar a festa sempre está com Matemático por seu conhecimento empírico maior. Conhecer os convidados e o lugar onde se deu o "asado" dá o poder da narração a Matemático, como se pode ver no fragmento seguinte depois que o outro caminhante confessa que não foi ao evento: 
Imaginémonos un jugador que, desde hace un buen rato, tiene en su poder la carta que va a permitirle ganar la partida pero que durante muchas vueltas no puede jugarla porque, de los otros jugadores, ninguna le da la ocasión de hacerlo; durante vueltas y vueltas, el jugador va tirando cartas inútiles, indiferentes, que no cambian para nada el curso de la partida, hasta que, de pronto, la combinación que necesita se forma sobre la mesa, permitiéndole lanzar, con euforia y decisión, la carta ganadora. La confesión retraida de Leto ha puesto, al Matemático en esa situación superior (2013, p. 29; grifo nosso).

Essa situação superior possibilita que Matemático relate àquele que desconhece a lembrança parasitária que possui desde o encontro com Botón. Entretanto, há um momento em que Matemático não consegue entender o sabor de mexericas postas na brasa. Somente nesse momento há uma inversão de conhecimento empírico sobre essa experiência específica, uma vez que Leto conhece esse sabor, mas isso não quer dizer que possa contá-lo porque o sabor é indescritível, já que também pertence à ordem do íntimo e do intransmissível.

Essa assimetria de conhecimento não impede a conversa sobre o aniversário, mas a estimula. As reflexões anteriores vão de encontro com as considerações amplamente conhecidas de Walter Benjamin no mesmo ensaio referido acima sobre o desaparecimento da figura do narrador, representante de uma tradição da comunicação de experiência por meio da arte de narrar que a ascensão do romance e os traumas de guerra fazem desaparecer. $\mathrm{O}$ declínio da partilha do sensível e, por conseguinte, da capacidade de transmitir vivências produz uma sociedade mais pobre em termos de experiências comunicáveis, no sentido de ocorrer uma diluição da única matéria narrável, a vida humana.

Entretanto, a narrativa da festa é um processo coletivo, não no sentido harmônico entre narradores e ouvintes, mas sim na necessidade do outro para transformar a lembrança em relato e para criar laços afetivos. O contato entre os personagens são encontros e confrontações sobre um acontecimento comum que nunca formam uma memória única ou consensual.

A necessidade do outro para transformar as lembranças em narração não constrói uma memória harmônica, mas edifica uma memória caleidoscópica de um mesmo evento importante em graus diferentes ou por motivos diversos para cada membro da rede de amigos: para Botón, a festa lhe permite fabular e atualizar o prazer que sentiu em se reunir com os amigos; no caso de Tomatis, o relato do "asado" revela toda a sua acidez e ironia para com os convidados; por sua vez, para Pichón, a festa está em um tempo mais longínquo, mas continua 
sendo um momento prazeroso em que todos os membros da rede, inclusive o ausente Matemático, participaram; e para os protagonistas, é a oportunidade de garantir de certa forma a sua existência no círculo de amigos.

A caminhada compartilhada e o que conversam é fundamental para gerar uma partilha parcial de percepções, aquilo que Agamben (2009) em "O amigo" chama de con-divisão do ser. O trecho abaixo está em uma das últimas páginas das primeiras sete quadras - primeira parte de Glosa - e mostra que o relato que reconstroem na conversa com versões alheias suscita um laço entre os caminhantes:

\footnotetext{
Desde que empezaron a recorrer juntos la calle recta [...], un nuevo lazo, impalpable, los emparenta: los recuerdos falsos de un lugar que nunca han visitado, de hechos que nunca presenciaron y de personas que nunca conocieron, de un día de fin de invierno que no está inscripto en la experiencia pero que sobresale, intenso, en la memoria [...] (2013,p. 85).
}

A caminhada é um tempo-espaço que conflui amigos no seu particular processo de construir lembranças alheias e próprias de um passado mítico-lendário que começa a fazer parte da memória de cada um dos membros, mas de maneira bastante imprecisa. Agamben (2009) postula que os amigos não con-divivem algo, mas sim a própria experiência da amizade. Essa se materializa no passeio que evoca lembranças alheias de um "asado", no qual se dão debates regados a carne e álcool, e isso possibilita que os ausentes também tenham palavra nessas conversas, o que parece dar maior intensidade ao laço de amizade entre os dois. Tal con-divisão não se restringe somente ao relato do evento e ao passeio em si, mas há experiências estéticas como a escuta de uma música, a leitura de um poema ou a observação repentina de um quadro. Analisaremos essas últimas cenas porque a necessidade dos amigos para con-dividir uma impressão estética são mais desenvolvidas.

De acordo com Ricci (2009) em "La condición inmortal”, a literatura e a leitura são um assunto e uma ação privilegiados entre os amigos da comunidade de personagens saeriana. Por exemplo, a cena de leitura do poema de Tomatis demonstra que os laços de amizade criam um circuito reduzido, no qual os amigos são os primeiros leitores. Depois que Tomatis lê o seu poema, o narrador relata que Matemático entrecerra os seus olhos para tornar explícito, diante de Leto, o privilégio de uma leitura privada desse texto literário.

Depois da leitura, os dois demandam com o olhar um comentário de Leto, que pede para que Tomatis o leia outra vez. Isso incomoda bastante o autor do poema por pensar que o 
texto não atendeu as expectativas do amigo "leitor", o que o narrador externo à narrativa diz não ser verdade porque Leto, distraído por pensamentos alheios à leitura, não escutou. A emoção estética esperada não se dá novamente justamente porque sente-se obrigado a demonstrar uma maior atenção por se sentir vigiado pelos dois. Tal fracasso parece aumentar o sentimento de exclusão de Leto em relação ao triângulo de amigos presente nessa cena de leitura. Ademais, o fato de Tomatis dar a Matemático o papel com o poema o torna um presente ao amigo que lhe pediu uma cópia e prestou atenção na leitura.

Por sua vez, a reação de Leto a uma pintura parece ser efetiva e atender às expectativas do amigo. Em uma das refutações aos comentários venenosos de Tomatis, Matemático usa como um contra-argumento repentino o direito da convidada e pintora Rita Fonseca a mostrar os seios quando bêbada pelo seu inquestionável talento artístico. Magicamente depois disso, aponta ironicamente o narrador, os caminhantes param diante de uma vitrine onde um dos quadros da pintora está exposto. Esse e sua técnica são detalhadamente descritos desde a perspectiva de Leto, que dessa vez ignora a atenção de Matemático a sua atenção estética. Mesmo assim, o último tem um orgulho múltiplo por distintos motivos:

\footnotetext{
Hay como un orgullo múltiple en el Matemático, primero por haberle señalado a Leto la presencia de un artista de valor, ya que siempre es agradable y tranquilizador haber sido de los primeros en cualquier cosa, después porque se ha dado cuenta de que la admiración de Leto es sincera lo cual confirma en cierto modo su propio gusto artístico, ¿no?, y por último, a causa de la refutación, sin gasto de argumentos, con la simple presentación de pruebas, de otra calumnia de Tomatis, o en todo caso de su selección tendenciosa, como dicen, ¿no?, de los hechos (2013, p. 183).
}

As duas primeiras razões tem a ver com o compartilhamento de uma opinião estética, que atesta a opinião compartilhada sobre a qualidade primeira e original da pintura. A última tem relação com a constante tentativa de Matemático de que Leto confie mais na sua posição enquanto narrador e refute o poder de Tomatis, algo que não ocorre, como se viu no ponto anterior.

Paul Ricoeur (2007) em A memória, a história e o esquecimento defende que a partilha da memória entre indivíduos próximos permite a sua reconstituição por meio de pontos de vista diferentes, não sendo somente outra forma de relatar o passado, mas sim a constituição de um "nós", no qual o "eu" é parte da memória do "outro" e "outro" é parte da 
memória do "eu". Em Glosa, as versões da festa se justapõem e mostram como o conflito entre os amigos incide sobre a memória do círculo, composta por lembranças singulares que se baseiam nas lembranças dos outros e vice-versa. Por exemplo, a recepção de Leto se compõe basicamente de experiências alheias ao grupo de amigos que recentemente conheceu, também da versão de Tomatis e da de Matemático, que, por sua vez, tem por base a versão de Botón e a sua própria experiência como membro do grupo. A memória do grupo não homogeniza as lembranças dos seus membros, mas a glosa das lembranças de um mesmo acontecimento mostram a instabilidade e fragilidade dos laços dessa pequena comunidade. Mas, paradoxalmente, são essas mesmas atividades que auxiliam na manutenção dessas relações.

Portanto, não é somente o ponto de vista multisseletivo que está em jogo, mas o caráter de uma experiência que vai além do que personagens e narrador percebem empiricamente. Chamemos isso de experiência estético-narrativa, que passa a pertencer à memória verdadeira e própria dos ausentes e - menos evidentemente - dos presentes em certo acontecimento. A experiência se transforma em lembranças para continuar existindo e em relato para se compartilhar.

Estar ou não envolvido em tais experiências estético-narrativas é estar ou não con-dividindo a experiência da amizade. Por isso Tomatis se ressente quando Leto não parece prestar atenção a sua leitura, por isso Matemático fica satisfeito com a reação do mesmo personagem quando vê o quadro ou vigia a sua atenção a narração da festa. A experiência narrativa compartilhada da festa demonstra que Matemático reconhece em Leto um membro da rede de amigos. Por sua vez, apesar da insegurança em relação ao seu lugar nessa rede, o segundo reconhece o primeiro como um membro do círculo ao conferir-lhe o poder da narração. O laço dos dois pode ser débil e uma promessa de amizade, mas nenhum questiona a existência do outro no círculo de amigos, por mais que ambos questionem isso nas suas próprias consciências. Por esse motivo, a experiência narrativa e a consequente amizade acidental de Leto e Matemático garantem, provisoriamente, a sua co-existência como membros da rede de amigos.

\subsection{Dilatações, acidentes e tensões}

A amizade entre os caminhantes está no tempo do passeio. Este é cronologicamente 
concentrado em exatos quarenta e cinco minutos, mas se estende no tempo da leitura: a amizade vai co-existindo nessa dilatação. Portanto, além das rememorações que se desenvolvem e se compartilham, a caminhada em si mesma é fundamental na construção e na explicitação da relação de amizade entre Matemático e Leto, pois a experiência narrativa na conversa está completamente entrelaçada com a experiência da caminhada ao ponto de uma não prosseguir sem a outra: a narração da festa segue somente quando os personagens estão caminhando e se interrompe quando atravessam a rua. Por exemplo:

Y los mellizos... dice el Matemático. Empiezan a cruzar; [...] ; vacilan [...], atraviesan la transversal [...], y llegan a la vereda de enfrente. [.... Al Al bajar a la calle, el Matemático se ha callado, posponiendo lo que estaba por decir, y adoptando una expresión vigilante al ver venir el auto colorado, un aire de vacilación ostentosa cuando el auto, parándose en la esquina, les corta el paso; y, cuando dejan atrás el auto, al aire vacilante lo sucede un sacudimiento distraído y reprobatorio de la cabeza, que se detiene cuando llegan a la vereda de enfrente. "Los mellizos Garay", va, por su parte, pensando Leto. Los mellizos, retoma el Matemático cuando entran en la sombra de los árboles, consiguieron una serpentina para instalar un barril de chop (2013,p. 43, grifos do autor).

Matemático começa a falar sobre os gêmeos, se interrompe para prestar maior atenção ao que está a sua volta enquanto atravessam a transversal e retoma o fio da narração da festa quando chegam à calçada em frente e entram na sombra das árvores. Além do mais, no fragmento que anteriormente vimos, Matemático convida Leto a acompanhá-lo na caminhada. Inicialmente, o primeiro parece guiar os passos do segundo e este docilmente o acompanha. Entretanto, há momentos mais adiante em que o narrador externo à narrativa descreve o passo dos caminhantes como tão coordenado que não sabe quem se adapta a quem:

A pesar de la diferencia de estatura, Leto y el Matemático llevan el mismo paso, ni lento ni rápido, tan bien coordinado que no puede saberse si es el Matemático el que reduce la extensión de sus trancos para igualarlos a los pasos de Leto o si, por el contrario, las piernas más flacas y más cortas de Leto se acomodan, sin esfuerzo visible, a la marcha del rugbyman adepto a la scientia recte judicandi $(2013$, p. 28 , grifo do autor).

Mais a frente, o narrador descreve uma força integradora dos caminhantes com o espaço e tempo em que a irregularidade do pensamento dos personagens se opõe a regularidade do ritmo dos seus movimentos:

Durante los veintisiete segundos [...] que le ha llevado al Matemático reconcentrarse, mudo, en sus pensamientos, y a Leto recordar, con imágenes 
rápidas, fragmentarias y sin orden cronológico [...] sus cuerpos progresan, ellos sí regulares, por la vereda estrecha, hacia el Sur. [...] [Os dois] van avanzando en el tiempo a medida que lo hacen en el espacio, como si cada paso que diesen los encaminara en direcciones opuestas, a menos que tiempo y espacio sean inseparables y el uno fuese inconcebible sin el otro, y ambos inconcebibles sin ellos dos, Leto y el Matemático, de modo tal que caminantes, calle y mañana, formasen un chorro espeso [...] (2013, p. 76, grifo nosso).

Além dessa harmonia física dos corpos dos personagens, os dois demonstram uma atitude protetora em relação ao outro em distintas partes da caminhada, projeção afetiva dos laços da amizade incipiente entre os protagonistas. Em alguns momentos em que a conversa sobre a festa se interrompe, cada um deles parece se preocupar com os passos do outro quando atravessam as ruas e caminham pelas calçadas. Por exemplo, Matemático segura Leto afetuosamente pelo braço e o faz seguir um ritmo rápido quando cruzam para "protegerlo contra la agresión eventual de alguno de los autos que vienen por la transversal" (2013, p. 58).

Essa mesma atitude afetuosa é recíproca e se estende por muitas páginas. Leto nota uma preocupação excessiva de Matemático com a integridade das suas calças brancas e, em seguida, percebe que a roupa parece ser uma extensão de todo o seu ser. Em vista disso, conduz a travessia da rua e incita Matemático a segui-lo. Como Leto no início do passeio, Matemático o segue docilmente e se abandona nas mãos do outro. Leto magnifica as suas dificuldades em atravessar a rua cheia de carros muito próximos entre si para não humilhar o acompanhante. Essa atitude protetora e afetuosa se explica na seguinte passagem:

[...] tratando de no ser sorprendido, [Leto] vigila los pantalones blancos mientras atraviesan, volviendo discreto la cabeza, deseando a su vez que la mancha no se produzca, no por identificación simpática, sino por temor de que la mancha remache la abyección, la complete $\mathrm{y}$, ante sus ojos, el Matemático, que a pesar de las insinuaciones de Tomatis, le parece alguien digno de amor y de cierta admiración, no naufrague en la zona oscura y pastosa de la que el aire claro de la mañana es el reverso endeble y pasajero. Pero por suerte,con prudencia y pericia, logran atravesar (2013, p. 175, grifo nosso).

Leto vislumbra a fragilidade de Matemático e teme que a imagem digna de amor se rompa diante dos seus olhos, que a certa admiração incipiente que sente por causa da conversa e da caminhada naufrague em uma "zona oscura y pastosa". Diante da imagem de Matemático sob ameaça, Leto o guia e "sacrifica" a integridade de suas próprias calças para que as de Matemático não se manchem.

Mais a frente, Leto pensa que Matemático está distraído com a narração da festa e não está prestando atenção no fim de uma quadra e calçada. Sua atitude protetora ressurge, mas o 
narrador externo à narrativa mostra que se engana porque Matemático não tropeça no meio-fio da calçada e nem perde o fio da narração. Esse cuidado com o outro leva o próprio Leto a tropeçar e a quase cair, algo que não acontece porque os braços "fraternales" de Matemático o seguram. No entanto, essa atitude recíproca de proteção mostra outra vez a sua afeição para com o acompanhante.

Além do mais, a relação que surge entre os protagonistas é acidental e racionalmente inexplicável:

\begin{abstract}
Al oír el segundo chistido, Leto advierte que, distraído, ha oído también el primero y se da vuelta. [....] el Matemático [...] ha reconocido a Leto y se ha puesto a chistarle para que pare y lo espere. [...]. El Matemático [...] lo alcanza y le estrecha la mano. ¿Qué se cuenta?, dice. Sin mirarlo a los ojos, Leto responde con vaguedad. $Y$, dice, aquí andamos (2013, p. 22, grifos do autor).
\end{abstract}

A casualidade e gratuidade do encontro entre os protagonistas se mostram durante toda a caminhada no romance em questão. A formação do vínculo entre os dois protagonistas não se explica completamente. Por exemplo, na passagem seguinte, depois de caminhar algumas quadras juntos, Matemático subitamente pára, pede que Leto o espere e entra na redação de um jornal com um anúncio do grêmio dos estudantes de química, sua associação:

\footnotetext{
—Vuelvo en seguida — dice, inesperado, el Matemático y, sacando del bolsillo del pantalón varias hojas dobladas en cuatro, entra en el edificio de La Mañana. [...] Y además: "Se fue de golpe para obligarme a esperarlo". Aceptando, dócil, la necesidad inexplicable de su compañia que parece sentir el Matemático, se apoya en el tronco del último árbol que bordea la vereda (2013, p. 48, grifo nosso).
}

Acima, Leto aguarda Matemático, sem conseguir explicar a necessidade de companhia. Provavelmente, os dois caminhantes necessitam que a conversa sobre um evento importante para o círculo de amigos prossiga para que os relatos e glosas da festa mantenham os seus desejos de continuar a co-existir na comunidade de amigos. Entretanto, a amizade dos protagonistas é acidental, não planejada.

Em suma, assim como a conversa que evoca o aniversário, a caminhada em si aproxima os personagens fisicamente no ritmo harmônico de corpos. Entretanto, não é a harmonia e a congruência que o narrador externo à narrativa mostra na consciência dos personagens. A força da experiência e da lembrança podem unir ou separar os personagens. A conversa e a relação entre Leto e Matemático estão em uma constante tensão entre a união 
que a conversa sobre o aniversário e a caminhada em si propiciam aos protagonistas e uma separação que lembranças particulares que os dois não compartilham provocam.

Antes de se encontrar com Matemático, e em muitos momentos ao longo da conversa, Leto pensa no seu drama familiar, o recente suicídio do seu pai. De acordo com o que percebe nesse grupo, ele chega à conclusão de que a sua mãe tenta encontrar a razão para o suicídio do seu pai em uma doença mortal, fantasia incentivada por sua família. Apesar de tentar não se afetar, a consciência de Leto volta uma e outra vez às lembranças de sua relação distante e problemática com seus parentes: a sua incapacidade de ter uma relação próxima com o seu pai, de entender as atitudes e expectativas da sua mãe, etc. Tal distanciamento mostra que seus parentes representam uma "comedia", farsa na qual ele não está incluído.

Em contrapartida, a interferência de outras lembranças na consciência do outro protagonista é menor que em Leto, mas também se concentra em um momento que o próprio personagem chama de "Episodio": Matemático foi excluído de um encontro com um poeta que visitava a cidade. Nesse momento, o protagonista sofre um intenso sentimento de exclusão que desestabiliza a ideia que possui de si mesmo.

Essas interferências são possíveis, pois o narrador externo à narrativa mostra que a memória dos personagens funciona como uma "chapita móvil". Observemos o seguinte fragmento:

\footnotetext{
Leto, aunque no su cuerpo, ya se ha olvidado de su madre y es esa misma sombra húmeda que persiste ahora, alrededor de las diez, en la calle principal, y que envuelve su cuerpo como una primera capa transparente de mundo que está a su vez envuelta en la mañana soleada, lo que lo hace volver a recordarla, a proyectarla en la chapita móvil y cambiante de sus representaciones contra la que destella, por momentos, el reflector minúsculo de la atención (2013, p. 16 - 17, grifo meu).
}

Acima, a memória de Leto se define a partir desta imagem: a chapinha móvel e mutante do refletor minúsculo da atenção é a consciência de Leto. Essa chapinha move a sua atenção entre a lembrança da sua mãe e o que está a sua volta, a rua e o sol. Tal imagem define a forma como o narrador externo à narrativa mostra o movimento da consciência dos protagonistas durante a caminhada: Leto e Matemático têm lembranças involuntárias que tiram, momentaneamente, a atenção de ambos da conversa sobre o evento em que nenhum dos dois participou.

Outra imagem que o narrador externo à narrativa usa é a imersão e a submersão de 
pensamentos na "ciénaga de la memoria". No seguinte trecho, depois de um encontro mais ou menos perturbador com Tomatis, Matemático e Leto emergem dos seus pensamentos e recuperam o fio da conversa:

[Matemático] Ha tenido que vencer [...] las oleadas fugaces del Episodio [...] De modo que, [...] advirtiendo que Leto [...] parece emerger también de sus pensamientos y se dispone a retomar la conversación, el Matemático yergue la cabeza, satisfecho, y [...] mira con euforia o firmeza la calle soleada y recta que se extiende ante él. [...] Su entusiasmo [...] se propaga hasta el propio Leto que, casi al mismo tiempo que él, sale de su propio ensimismamiento y siente que el hecho de estar ahí, en el presente y no en la ciénaga de la memoria (2013, p. 154, grifo nosso).

Antes imersos nos seus próprios pensamentos, os dois emergem para a rua em uma manhã ensolarada e para a conversa que os une. Sendo assim, tais lembranças involuntárias separam os dois protagonistas da conversa e do exterior que os rodeia momentaneamente, mas nunca completamente. A co-existência com o amigo diminui o peso, mesmo que temporariamente e nunca permanentemente, da solidão desses personagens com a alegria desses encontros.

A dinâmica da amizade entre Leto e Matemático é claramente frágil e incipiente: o decorrer da caminhada dissolve uma amizade que não teve tempo para se solidificar, mas o narrador faz o leitor se deter nesses encontros efêmeros que se transformam em duradouros pela narração e leitura. A experiência do instante se prolonga no relato da memória.

No fim da caminhada, o narrador externo à narrativa "traduz" as impressões que cada um tem do outro. Essas estão carregadas de um afeto que se desenvolveu ao longo do passeio. A revelação de tais pontos de vista ressignifica uma conversa que até agora pareceu construir uma amizade que poderia ter ficado somente na promessa. Nessas passagens, os dois entendem o que um pensa do outro pelo olhar afável e rápido:

La [mirada] de Leto dice más o menos lo siguiente: Para ser francos, cuando me chistaste hace un rato, que me cuelguen si tenía cinco de ganas de que alguien venga a darme la lata durante quince cuadras, máxime que te conocía sobre todo por las referencias de Tomatis que son de lo más reticentes y que tu aspecto fisico y tus hábitos vestimentarios no nos favorecen mucho a los pobres mortales que nos paseamos en tu compañia. Pero después de nuestra caminata debo reconocer que tu persona, aunque no exenta de pedantería, es más bien agradable, y no lo hemos pasado del todo mal. Más todavía: en un determinado momento, pensé que la cosa se echaba a perder, pero no te preocupes: para mi el incidente del pantalón es como si no hubiese sucedido (p. 219, grifo do autor). 
O olhar de Leto comunica a sua reticência a conversar com Matemático no início da caminhada por conhecê-lo minimamente pelas referências bastante críticas de Tomatis e pelo seu aspecto físico que no início é definido como o de um modelo em um cartaz publicitário. Mas a caminhada transforma a impressão anterior de Leto e reconhece em Matemático uma pessoa agradável, imagem que quase desmoronou pelo “incidente del pantalón”. Como se observou, Leto o salva para que essa nova e boa percepção daquele que o acompanha se mantenha.

Por sua vez, o olhar de Matemático comunica o seguinte:

\begin{abstract}
Me doy cuenta de tus reticencias. Trato de comprenderlas. Y estoy al tanto también de las de Tomatis. Pero no me importa. Ustedes, como he nacido entre gente que no es interesante, perciben en mí elementos no interesantes, que son la causa, justificada sin duda, de esas reticencias. Tomemos el caso de mi pantalón. Ya sé que no debo acordarle tanta importancia. Pero es más fuerte que yo. En determinado momento, si mi pantalón blanco está en peligro, todo mi ser parece estar en peligro, porque todo mi ser-vaya saber por qué causa, sin duda debido a esos elementos no interesantes que persisten en mi a pesar de mis esfuerzos por anularlos-aunque parezca extraño, se concentra en mi pantalón. Pero yo también podría hacer objeciones si quisiese. Tomatis por ejemplo, no estuvo muy brillante que digamos. Y en tu caso, no estoy seguro de que hayas entendido todo lo que, con tanta paciencia, detalles y respeto escrupuloso de la verdad, he estado tratando de contarte. Más de una vez te sorprendi pensando en otra cosa, y en un momento dado temi que te aprovecharas demasiado del incidente de los pantalones. Pero para qué detenerme en todo esto-son insignificancias que pertenecen al orden de lo no interesante. ¿No te parece que hay cosas más importantes en las que ocupar el tiempo que nos ha sido acordado? De Rerum Natura o la Etica de Spinoza, por ejemplo, o el debate que opone los partidarios de la paradoja EPR a los de la Interpretación (2013, p. 220 , grifo do autor).
\end{abstract}

Matemático percebe a reticência de Tomatis e Leto e trata de justificá-las observando que Leto não prestava total atenção ao que lhe falava e que tinha se aproveitado muito do “incidente de los pantalones". Em seguida, esse protagonista não dá muita importância à resistência do novo amigo e tenta, ao longo de toda a conversa, compreendê-la e ultrapassá-la para que Leto mude de ideia a seu respeito, o que acontece.

Os fragmentos de pensamento, tanto de um personagem como de outro, adquirem um novo sentido no momento em que a conversa termina. Os dois constroem uma percepção aguda - mesmo que fragmentária, opaca e, muitas vezes, equivocada - sobre o acompanhante provavelmente porque Leto e Matemático aproveitaram o momento do passeio e estiveram dispostos a construir uma relação de amizade ao longo da conversa na caminhada, um curto período de tempo cronológico dilatado no tempo da leitura do romance. E Matemático, de 
quem o leitor conhece menos os pensamentos, tem uma agudíssima interpretação de como é percebido pelos outros amigos, como também de si mesmo, mais do que Leto, que parece não conhecer a si mesmo. O laço que se estabelece entre eles dura pouco, mas foi possível e se construiu ao longo das quadras do centro de uma inominada cidade.

A amizade efêmera entre os caminhantes poderia, mas não vai, além do passeio, como o narrador mostra no seguinte trecho:

apenas si [Leto e Matemático] estarán juntos en dos o tres veces, en algunas reuniones en las que intercambiarán unas pocas palabras y, cuando se encontrarán, en la calle, se limitarán a cruzar un saludo, cortés sin duda, pero sin pararse a conversar (2013, p.224).

De acordo com Ricci (2009), isso se dá porque entre os dois não existe confiança, um código comum e um vínculo inquebrável, o que caracterizaria as relações mais duráveis entre os amigos na narrativa saeriana. Entretanto, o texto anterior não pontua que o presente do romance está vinculado ao efêmero do tempo-espaço da caminhada, o que gera uma relação também fugaz. Contudo, como já se observou, a fugacidade é estendida na narração para além do tempo cronológico que a caminhada e o relacionamento levam.

O modo de narrar intensifica e prolonga o início de uma amizade menos durável, o que dá importância para uma relação débil, mas também afetuosa. Ricci (2009) também observa que a amizade dos protagonistas se reforça como promessa em momentos críticos do passeio: o esquecimento involuntário de Matemático do amigo que o acompanha quando se encontra com Tomatis, o "incidente das calças" de Matemático e o tropeço de Leto. No entanto, é também nesses momentos que a amizade nascente entre os dois se torna mais evidente.

Como vimos anteriormente, Leto se sente excluído da conversa entre Tomatis e Matemático. Entretanto, o último tenta, sem sucesso, comunicar a Leto o seu desconcerto em relação ao comportamento do recém-chegado ao passeio. Em outra passagem do romance, diante do medo desproporcional de Matemático em sujar a suas calças, Leto protege a roupa por ser uma extensão da identidade do outro que, se "manchada", poderia destruir a imagem que foi fazendo ao longo do percurso do novo amigo. Mais adiante e depois desse incidente, Matemático salva afetuosamente Leto de uma queda.

Mais um momento crítico e fundamental se dá em um encontro com um parente de 
Matemático. Segue o seu início:

\begin{abstract}
Parado en medio de la vereda, [o parente de Matemático] los espera con una sonrisa vasta, dirigida exclusivamente al Matemático quien, le parece percibir a Leto, se la devuelve con reticencia. Pero cuando llegan junto a él, el Matemático le tiende [...] una mano displicente que el otro estrecha [...] Y Leto está a punto de empezar a sentirse otra vez transparente, como en presencia de Tomatis, cuando en forma inesperada [...] el Matemático los presenta: ¿Se conocen? Mi amigo Leto. El doctor Méndez Mantaras. Y después, como para disculparse ante Leto, agrega: Somos medio parientes (2013,p. 201, grifos do autor).
\end{abstract}

Acima, Leto está a ponto de se sentir novamente invisível, quando Matemático o apresenta como "mi amigo Leto". Ao longo de todo esse encontro, o primeiro fala com o parente, mas parece dirigir a sua fala ao amigo, no sentido de mostrar o seu desdém ao "medio pariente" e aos de sua classe social. Leto pensa que esse desprezo é uma forma de sedução:

Pero también, y sobre todo, se siente agradecido porque le ha parecido percibir, en el desprecio un poco brutal del Matemático por su medio pariente, un acto de seducción hacia su propia persona, que, inesperado y fugaz, lo hace existir de un modo más intenso (2013, p. 208).

Leto existe "de un modo más intenso" porque percebe que Matemático se importa com o que pensa a seu respeito. Mesmo sendo um amigo incipiente, o primeiro quer que o último o reconheça como alguém oposto ao parente que encontram por acaso.

Em Modernidade Líquida, Zygmunt Bauman (2008) sustenta que o encontro com o outro interrompe momentaneamente a solidão do indivíduo em uma sociedade onde o individualismo é característica central da vida humana. Por isso, alguns relacionamentos são menos duráveis e, por conseguinte, mais fáceis de se romperem. Em Glosa, apesar dos protagonistas garantirem temporariamente a sua co-existência no círculo de amigos por meio de uma narrativa compartilhada, o laço que se estabelece entre ambos é frágil.

Poder-se-ia objetar que nem um princípio de amizade ocorre entre Matemático e Leto, que quarenta e cinco minutos são insuficientes para estabelecer qualquer laço. Entretanto, a amizade em Glosa é um dinamismo vivo que depende de cada um dos envolvidos na relação. Por isso, estabilidade ou instabilidade, manutenção ou corte de laços são responsabilidades dos membros e da História, como se verá na terceira parte desta pesquisa. Lembrar e narrar são tarefas árduas, mas a experiência da amizade que ambas suscitam faz valê-las a pena, mesmo que a relação seja frágil e instável, assim como a tentativa da narração de instantes 
efêmeros e fugazes em um amálgama de relatos dissonantes. Descobrimos comunidade e amizade onde normalmente não a enxergamos.

\title{
1.5 Personagens
}

Até agora, vimos como a narração da festa resulta especialmente da amizade que os protagonistas e alguns amigos presentes na celebração têm entre si. Em seguida, veremos como essa relação opaca, distante, fluida e conflitiva também influencia na construção dos personagens. Esses são opacos e, por isso, múltiplos.

\subsubsection{Opacos}

De acordo com Umberto Eco (2013) em “Alguns comentários sobre os personagens de ficção", os personagens são indeterminados porque o leitor conhece poucos dos seus atributos físicos e psicológicos. Por sua vez, as pessoas reais são "determinadas", pois se pode conhecer muito das suas características. Sobre esse ponto, em uma entrevista para a Revista $\tilde{N}$ do jornal argentino Clarín $^{21}$, Juan José Saer não distingue pessoas reais e personagens quando fala sobre a construção dos últimos na sua narrativa:

\begin{abstract}
la forma de concebir a los personajes debe cambiar a medida que cambia nuestra concepción del hombre. Nuestra percepción del tiempo, de la interioridad de los otros, del cuerpo, está en permanente transformación. Si alguien quiere escribir algo interesante lo debe tener en cuenta. Fijate que en verdad no sabemos demasiado de Tomatis. Sabemos algo de él cuando aparece. Yo sé algo de vos cada vez que aparecés. Lo curioso es que no sólo tenemos esa visión fragmentaria de aquellas personas que vemos cada tanto, sino también de nuestras personas más próximas, e incluso de nosotros mismos. En mis textos intento trabajar con la incertidumbre porque me parece que ese es nuestro fondo mental (grifos nossos).
\end{abstract}

Entretanto, os personagens em Glosa não são turvos somente pela sua fragmentariedade, mas também porque esses seres não compartilham realmente pensamentos, percepções e lembranças. Eles não são profundos, rasos, redondos, planos ou transparentes, mas sim opacos ${ }^{22}$. Seus graus de opacidade se revelam quanto mais o narrador, a comunidade

\footnotetext{
${ }^{21}$ SAER, Juan José;ABBATE, Florencia. "El legado de Juan José Saer. El principio de incertidumbre”. Revista N. Clarín.com, Buenos Aires, 01 out. 2005. Disponível em: $<$ http://edant.clarin.com/suplementos/cultura/2005/10/01/u-01014517.htm>. Acesso em: 30 nov. 2016.

${ }^{22}$ Em Como funciona a ficção, James Wood (2002) defende que as metáforas espaciais que dividem os personagens em profundos ou rasos e redondos ou planos são inadequadas. Por isso, propõe que se pense nos personagens como transparentes - personagens simples - ou opacos, mais complexos de acordo com os seus graus de mistério.
} 
de amigos e o leitor se detém sobre eles.

Segundo Jean-Philippe Miraux (2005) em El personaje en la novela, a partir de meados do século XX o personagem se transformou em um lugar privilegiado de suspeita mútua entre leitor e narrador em muitos romances, tornando-o cada vez mais inapreensível e indefinível. No caso da narrativa em análise, os personagens-amigos não se conhecem, pois todo conhecimento é relativo, provisório e, muitas vezes, negado.

De acordo com Maurice Blanchot (1976) em "La amistad”, o amigo não é aquele com quem se compartilha interesses e desejos ou que se conhece intimamente. Do amigo não se fala porque não é um sujeito cognoscível, mas um ser com quem se conversa, se invoca, sem compreendê-lo e, portanto, apropriá-lo. Sendo assim, essa relação reconhece a alteridade do amigo, o que possibilita uma paradoxal cumplicidade com o desconhecido e com o distante. A amizade em Glosa, especialmente entre os protagonistas, não pressupõe intimidade, mas sim a percepção do amigo como uma exterioridade misteriosa e inacessível, por mais que haja a tentativa conhecê-lo intimamente. Momentos como os que seguem são bastante recorrentes no romance.

Em muitas passagens, um personagem tenta entender o que o outro com quem conversa quer dizer. No seguinte trecho, Tomatis usa uma frase feita para falar que nem todos os presentes eram importantes e nem todos os ausentes eram indignos de participar do evento. Leto se pergunta se a expressão é uma maneira do amigo insinuar que ele é importante para a rede, apesar de não ter estado no evento: "Como en el dicho: no están todos los que son ni son todos los que están. Leto lo mira: ¿es una cortesía hacia su persona?” (2013,p. 45, grifo nosso).

Em outras, um dos protagonistas busca comunicar com gestos e olhares uma cumplicidade, mas essas tentativas fracassam, como no seguinte fragmento: "el Matemático trata sin resultado de cruzar una mirada rápida de complicidad con Leto por encima de la cabeza de Tomatis" (2013, p. 118, grifo nosso). Essa busca pelo apoio do novo amigo é parte da sedução de qualquer relação. Entretanto, essa não tem o efeito esperado porque nenhum dos amigos interpreta com sucesso o que o outro fala e faz.

Existem muitos momentos em que o narrador enfatiza que a interpretação que cada personagem dá a uma expressão, gesto ou atitude é equivocada. Por exemplo, quando os dois caminham em silêncio: 
Durante varios metros, caminan sin hablar. Leto cree que el Matemático, ofendido al comprobar que él se cruzó de vereda [...] se ha encerrado de un modo deliberado en sí mismo para mostrarle su reprobación, pero lo que en realidad pasa [...] (2013, p. 56, grifo nosso).

Além disso, acima se nota que não são somente as lembranças involuntárias e traumáticas que cortam o fio da conversa sobre a festa. Sobre isso, Ricci (2009) observa que os protagonistas se ausentam da caminhada e da conversação não só pelas irrupções de lembranças íntimas nas suas consciências, mas também porque os dois fazem várias conjecturas sobre as motivações que estão por trás do que o acompanhante fala e faz.

Assim como os comentários sobre a festa, essas tentativas de interpretação não resultam no conhecimento sobre o novo amigo, mas mostram um interesse pelo que um pensa do outro, preocupação que uma amizade, recente ou não, pode suscitar:

Matemático acaba [...] de preguntarle si ha estado en el cumpleaños de Washington, y como él, [...] ha respondido que no, teme ahora que el otro, que está como acechándolo, esté acechándolo no con desprecio, sino con extrañeza y con cierta compasión (2013, p. 30).

Um sentimento de compaixão semelhante leva Leto a proteger Matemático e suas calças para que a imagem que foi produzindo daquele que o acompanha no passeio se mantenha. Como se mostrou anteriormente, essa percepção se constrói contrariando o ponto de vista de Tomatis sobre Matemático, prévio à caminhada dos protagonistas. $\mathrm{O}$ último pode ser digno de amor e admiração e o que Leto protege no fim é esse afeto nascente.

Em “La condición mortal”, Beatriz Sarlo (2010) ressalta que a narrativa saeriana não celebra o desaparecimento do sólido e discernível personagem realista do século XIX, mas cria seres de distinta natureza. Segundo Miraux (2005), os personagens constroem e movem a trama - no caso de Glosa, em especial a narração múltipla do seu centro argumentativo -, mas vivem, atuam, existem e falam em função da narração.

Os personagens-amigos se ligam, entre outras coisas, por um afeto e por um interesse em torno do que o outro pensa e fala, por mais que esse conhecimento seja incerto, falho e, portanto, não acessível. As tentativas fracassadas de conhecer um ao outro favorecem a exploração das dimensões especulativas desses seres, mais uma vez por meio de um choque de múltiplas vozes, o que veremos no próximo ponto. 


\title{
1.5.2 Múltiplos
}

Voltando a Eco (2013) e suas reflexões sobre o personagem:

[...] [N]inguém pode determinar as propriedades de determinado indivíduo ou determinada espécie, que são potencialmente infinitas, enquanto as propriedades dos personagens de ficção são muito limitadas pelo texto narrativo - e apenas aqueles atributos mencionados pelos textos valem para a identificação do personagem ( $\mathrm{p}$. 76).

No entanto, o autor não leva em consideração que os "atributos mencionados para a identificação do personagem" podem sugerir potências infinitas ou, pelo menos, mutantes.

No trecho seguinte trecho de uma entrevista ${ }^{23}$, Saer discorre sobre a visão que tem de sua obra:

\begin{abstract}
Yo tengo una visión de mis libros todavía más fragmentaria de la que tienen los lectores. Basho, el poeta japonés, describe su poética como compuesta de un elemento estable y un elemento fluido. Esto, creo, es válido para el arte en general. En la música, Bach es un ejemplo. En él encontramos un sistema muy codificado, y en el interior de ese sistema hay una serie de innovaciones, de cambios. En cada repetición hay algo nuevo. Así en mis libros. Y no lo digo en cuanto a la realización efectiva de mi proyecto, sino en cuanto a mi intención. Por eso en mis libros aparecen elementos que ya han aparecido en otros, acompañados siempre de algún elemento nuevo. El elemento nuevo es casi siempre el protagónico. [...] Es un sistema en el cual hay muchas galerías, muchas formas de abordar, entrar, salir, y siempre cada uno de los tramos de ese sistema está inacabado, no tiene un sentido definido, todo se va construyendo, digamos, hacia una inconclusión final.
\end{abstract}

Ou seja, para o escritor, a sua narrativa é composta de variações de um mesmo sistema que vai se construindo, mas é inconcluso. Essas variações também estão no romance em análise. Em Glosa, os protagonistas evocam as versões de um mesmo acontecimento e os pontos de vista diversos sobre um mesmo personagem para construírem as suas próprias percepções sobre os membros da rede de amigos. Entretanto, como se viu anteriormente, essas variações não se amalgamam em uma percepção mais próxima do que realmente aconteceu, mas explicitam que o que os seres de papel percebem - a celebração, os personagens, etc.- é incerto, mutante e múltiplo.

\footnotetext{
${ }^{23}$ SAER, Juan José; VALLE, Gustavo. "Una incertidumbre elocuente (entrevista con Juan José Saer)". Letras libres, Madrid, $\quad$ n. $09, \quad$ jun. 2002. $\quad$ Disponível em: $<$ http://www.letraslibres.com/mexico-espana/la-incertidumbre-elocuenteentrevista-juan-jose-saer>. Acesso em: 30 nov. 2016.
} 
A voz narradora do romance em análise, nunca isenta de dúvidas, mostra múltiplos e heterogêneos pontos de vista sobre o que um personagem pensa do outro. Por exemplo, a imagem que Leto faz de Matemático é inicialmente mediada pela visão que Tomatis tem dele, mas se transforma ao longo da conversa, como dissemos mais acima.

Por sua vez, quando os caminhantes falam da amizade de outros personagens também ocorre esse desencontro de vozes, como nos comentários sobre a amizade de Cuello e o aniversariante, que dissonam nas vozes de Tomatis e Matemático: para o primeiro, Cuello é um traidor porque foi um dos responsáveis pela internação de Washington em um hospício no passado. Já, para Matemático, essa internação foi um modo desse amigo salvar o outro de uma possível prisão ou morte política.

Outro exemplo mais visível é como os protagonistas imaginam fisicamente Botón, no já mencionado fragmento:

Los dos se lo representan: el Matemático rubio, crespo, con el bigotito rubio [...], los ojos casi transparentes a causa del azul tan claro, recién bañado y peinado, [...], y Leto morocho, impreciso, la piel oscura, picada de viruelas, con el pelo bien lacio y un poco rebelde, de una dureza casi metálica [...] (2013,p. 64).

Além disso, Leto imagina esse convidado de acordo com a mutante descrição de Matemático:

El Matemático no vacila en poner en la balanza [...] defectos y virtudes de Botón, para gran contrariedad de Leto, que debe corregir la imagen un poco sumaria que ha venido elaborando; para él se trataba de un entrerriano morocho, picado de viruelas, estudiante de abogacía, más afecto al vino y a la guitarra que a los apuntes de Derecho Civil, violador aficionado en sus ratos libres, más bien populachero en sus gustos literarios, de inteligencia un poco obtusa, y ahora resulta que se trata de un muchacho exquisito, protector del arte de vanguardia, una especie de santo, capaz del más grande de los sacrificios — mantenerse sobrio - si un fin superior [...] se lo exige. Una sospecha empieza a apoderarse, como dicen, de Leto, a saber que el Matemático, por oponerse en forma radical a Tomatis, ha perdido el sentido crítico y exagera el lado bueno de las cosas, o peor aún [...] el Matemático, habiendo probado el gusto de la abyección humana, capaz de reducir a nada el todo con tal de no recibir una mancha en el propio pantalón, para redescubrir, podría decirse, la miel de la existencia, el bien disperso en el mundo, ve virtudes hasta en Botón (2013, p. 187, grifo nosso).

No início da conversa, para Matemático, Botón não era muito confiável, mas essa visão se transforma de maneira positiva, possivelmente para contrapor sua perspectiva à visão venenosa de Tomatis ou porque está com um melhor humor depois de ter passado pelo 
"incidente de los pantalones". Sendo assim, visões se contrapõem, se formam e se transformam.

Como se viu anteriormente, Leto também muda sua impressão em relação ao seu acompanhante, o que acontece a partir de um instante que se prolonga na narração. Em um lapso de tempo do passeio, a percepção do personagem se intensifica quando observa o amigo. Isso ocorre depois que Matemático interrompe sem motivo aparente a caminhada e a narração da festa e pede que Leto o espere enquanto vai entregar um comunicado em um jornal. É nesse reencontro com o acompanhante que ocorre o presente epifânico, bastante recorrente na narrativa saeriana, de acordo com Florencia Abbate (2014) em El espesor del presente: tiempo e historia en las novelas de Juan José Saer. A crítica cita o seguinte trecho de Glosa:

\begin{abstract}
Leto empieza a ver el conjunto, con el Matemático incluido, no como autos, ni árboles, ni casas, ni cielo, ni seres humanos, sino como un sistema de relaciones, de cuya creación no es sin duda ajena la combinación de movimientos diferentes, el Matemático hacia adelante, los autos cada uno en sentido distinto, las cosas inmóviles cambiando de aspecto y lugar en correspondencia con las que se mueven, todo en proporción perfecta y casual sin duda, de modo tal que, viviéndolo, o sintiéndolo, o como deba llamarse a su estado, pero sin pensarlo, Leto experimenta una alegría súbita, franca, de la que no sabe que es alegría y que acompaña, agudizándolas, sus percepciones. [...] el Matemático, al cruzar la calle, se ha transformado en un objeto bello, de una belleza abstracta y no relativa, que no tiene nada que ver con sus atributos preexistentes sino más bien con una coincidencia cósmica que reúne, durante unos pocos segundos, muchos elementos heterogéneos en una composición inestable y que, cuando el Matemático llega a la vereda y los dos autos se alejan un poco en dirección contraria, misteriosa, y habiendo existido únicamente para Leto, se disuelve (2013, p. 55).
\end{abstract}

A crítica sustenta que o presente epifânico é um lapso temporal em que os personagens saerianos acessam uma visão mais aguda porque há uma reconciliação entre tempo interior e tempo exterior, o que causa uma percepção estética e, portanto, prazerosa do mundo e do indivíduo diferente do "eu”. Entretanto, essas impressões não parecem ser compartilhadas, existem somente para o personagem em sua individualidade. Ademais, a harmonia momentânea entre o sujeito e o universo não torna o conhecimento menos opaco. Acima, Leto contempla Matemático e o exterior que o envolve, mas não o compreende.

Além disso, na passagem que segue, o narrador externo à narrativa mostra que a contemplação de Leto o leva a desconsiderar, temporariamente, as opiniões que tinha sobre Matemático: 
Independiente de su aspecto físico, de su vestimenta, incluso de su origen social o de una pose que esté adoptando, ni debido tampoco a una proyección afectiva de Leto, que comparte más bien las objeciones de Tomatis y lo conoce menos (2013, p. 55, grifo nosso).

Independente do dito acima, Matemático faz parte do presente epifânico percebido pelo outro protagonista. Apesar desse momento pleno para a subjetividade durar segundos, é depois disso que Leto começa a edificar suas próprias impressões sobre Matemático, desenhando dele uma nova imagem.

Para Miraux (2005), a construção dos personagens se dilui em perspectivas múltiplas, comprometendo sua completude. Entretanto, essa técnica contribui para a complexidade dessas criaturas e das suas relações porque as torna enigmáticas e, paradoxalmente, mais conhecidas, uma vez que são captados por ângulos diversos.

Por conseguinte, assim como as versões da festa são potências de um mesmo acontecimento passado, os personagens são seres potenciais que podem ser ou não de determinada forma e, portanto, não tem uma identidade essencial. Uma das principais funções do narrador de Glosa é explicitar essas potências.

Os personagens principais de Glosa são uma pluralidade de percepções divergentes e não conclusivas e, por isso, estão sempre em transformação. Nenhum deles permanece o mesmo ou se fecha. Os amigos-personagens são seres indeterminados e inapreensíveis em uma completude ou fixidez.

Estamos de acordo com Premat (2002) quando conclui que, na narrativa saeriana, as tentativas de apreensão de qualquer alteridade não são insignificantes, mas demonstram uma concepção de narrativa que se vale desses fracassos para preservar a força potencial da literatura. A focalização nas consciências e estados de ânimo dos personagens mostra minúsculas sensações, pequenos conflitos afetivos, passageiras impressões ou mal-entendidos, por mais que toda compreensão firme de um comportamento humano pareça fora de alcance. 
O amor. A amizade. O convívio. O júbilo do gol. A festa. A embriaguez. A poesia. A rebeldia. Os estados de graça. A possessão diabólica. A plenitude da carne. O orgasmo. Estas coisas não precisam de justificação nem de justificativas.

Todos sabemos que elas são a própria finalidade da vida (LEMINSKI, 1986).

\title{
2 FESTA, RISO, DOM
}

A dedicatória de Glosa encena o momento de entrega do texto como um presente, ou melhor, um dom ${ }^{24}$ e uma comédia:

\author{
A \\ Michel, Patrick, Pierre Gilles, \\ que practican las tres \\ ciencias verdaderas, \\ la gramática, la homeopatía, la administración, \\ el autor les dedica, \\ por las sobremesas de los domingos, \\ esta comedia:
}

but then time is you misfourtune father said.

(2013, p. 07, grifo do autor)

O fragmento em itálico é uma citação em inglês de $O$ som e a fúria (1929), romance de Wiliam Faulkner. Em “Temporalidad, fantasma y narración en 'Glosa' de Juan José Saer”, Silvana López (2012) sugere que a comédia é dada para ser desfrutada em um "agora" ou antes de que seja tarde porque o tempo transcorre infalivelmente e tanto o autor como seus amigos estão conscientes da finitude da existência humana.

A crítica sustenta que a comédia é um tom que suspende provisoriamente o tempo cronológico. Partindo das reflexões de Frank Kermode em El sentido de un fin, aponta duas distinções temporais quando vincula tempo e comédia: khronos e kairos. O primeiro é o tempo que passa e o segundo um ponto no tempo carregado de um sentido derivado da sua relação com o fim.

\footnotetext{
${ }^{24}$ Dialogaremos com a ideia de dom que Jacques Derrida (1995) desenvolve em Dar el tiempo: La moneda falsa. Nesse livro, ele explora a ideia de um dom impossível, sem objeto, doador ou receptor. Entretanto, um dom que renuncia a algum dos seus elementos é possível, como se verá a seguir.
} 
Sendo assim, por um lado, o autor convida os destinatários do texto - amigos-leitores a conversar, a ler e a levar adiante possíveis ações "antes" que o tempo passe no espaço em branco entre a primeira e a segunda parte da dedicatória de Glosa; por outro, a doação da comédia perfura a passagem do tempo, constituindo-se em um kairos, um ponto que suspende o khronos, uma fenda no devir inevitável. Portanto, como o próprio narrador afirma: "la comedia [...] es [...] tardanza de lo irremediable, silencio bondadoso sobre la progresión brutal de lo neutro, ilusión pasajera y gentil que celebra el error en lugar de maldecir” (2013, p. 198, grifo nosso).

Ademais, de acordo com Paulo Ricci (2009) em "La condición inmortal”, monografia em que analisa especialmente as dedicatórias dos livros de Juan José Saer, o escritor destina o romance a um grupo de amigos ${ }^{25}$ com o qual compartilhou "las sobremesas del domingo". Em vista disso, além da dedicatória ser um dom por si só, nessa também está uma cena de doação que antecipa o argumento central da narrativa - a tentativa de reconstrução do aniversário de Washington Noriega - quando alude a laços de amizade associados à comida e às conversas despreocupadas.

As reflexões acima dialogam com o que Jacques Derrida (1995) pensa sobre o dom em Dar el tiempo: la moneda falsa. A dedicatória antecipa que a narração que lhe segue realizará uma representação particular de temporalidade, o tempo que é dom para os amigos. Eles interrompem suas tarefas regulares para se reunir na festa e na caminhada. De acordo com o filósofo, esses instantes que fraturam a vida regular são dons sem retorno, pois não são algo que pertençam a alguém. $\mathrm{O}$ dom dá, requer e toma tempo.

Em Glosa, o narrador relata as pausas temporais desde as primeiras linhas do romance:

Leto [...] ha bajado, hace unos segundos, del colectivo, en la esquina del bulevar, muchas cuadras antes de donde lo hace por lo general, movido por las ganas repentinas de caminar, de atravesar a pie San Martín, la calle principal, y de dejarse envolver por la mañana soleada en lugar de encerrarse en el entrepiso sombrío de uno de esos negocios a los que, desde hace algunos meses, les viene llevando, con paciencia pero sin entusiasmo, los libros de contabilidad (2013, p. 13).

Leto salta do seu caminho para o trabalho, visto como um lugar sombrio, o contrário da manhã ensolarada em que se envolve quando começa a caminhar sem rumo por uma rua.

\footnotetext{
${ }^{25}$ De acordo com uma nota de Premat (2010) presente na edição crítica de Glosa e El Entenado, os destinatários são Michel Launay, Patrick Lamonte e Pierre Gilles Gueguen, amigos de Saer.
} 
Por sua vez, Matemático tem que interromper sua conversa com Leto quando vai fazer uma obrigação para a sua associação estudantil, entregar um relatório ao jornal local sobre sua viagem. Em seguida, volta a passear e a desperdiçar tempo conversando com o novo amigo sobre outro momento que fraturou a vida regular da rede, a festa.

Os amigos experimentam e levam em suas memórias instantes em comunidade dilatados pela narração, reuniões em que esbanjaram seu tempo entre si sem qualquer objetivo a não ser estar e rir juntos. Em Zona Saer, Beatriz Sarlo (2016) salienta que os personagens compartilham, muitas vezes de modo simultâneo, conversas, comidas e espaços:

La conversación es, como las comidas y sus acciones preparatorias (limpiar moncholos, carnear un animal, cortar pedazos de carne, sacar las escamas de un pescado, prender un fuego, calentar mandarinas al rescoldo), la respuesta a una pregunta si se quiere filosófica: ¿qué se hace cuando [aparentemente] no se hace nada? (p. 110).

As cenas fundamentais de convivência entre amigos são os "asados". Esses, para María Teresa Gramuglio (2010) em “El lugar de Saer”, são:

como ciertos motivos musicales en el interior de una partitura, [...] vuelven en estos pasajes la columna de humo ascendente, el rico jugo de la carne, los filamentos exangües de las pulpas masticadas, las texturas y los brillos de los alimentos, los chirridos de la cocción: imágenes cuyo denominador común, además, reside en la insistencia en la materialidad de los objetos y en el registro de la experiencia sensible de esa materialidad (p. 330).

A narrativa saeriana começa em um "asado". Por exemplo, "Algo se aproxima" última e mais longa narrativa de En la zona, primeiro livro do escritor - é a narração lenta de um "asado" organizado por dois estudantes, os jovens amigos Barco e outro personagem sem nome. Os homens preparam o fogo e assam a carne, enquanto as mulheres montam e temperam a salada. Por sua vez, as conversas narradas nessa comida, em que falam especialmente sobre assuntos literários, ocorrem fundamentalmente entre esses homens. Raramente, as mulheres participam ativamente das conversas entre eles e parecem ser somente as parceiras amorosas dos dois amigos, formando um sutil quadrado amoroso ${ }^{26}$. Em vista disso, Sarlo (2016) pontua que, na ficção saeriana, "las mujeres son literaria y

\footnotetext{
${ }^{26}$ Cf. "Las mujeres de Juan José Saer: Un análisis de 'En la zona' desde la estética femenista". Nesse breve artigo, Sebastián Ramiro Ampudia (2012) faz um estudo sobre a construção de algumas personagens femininas, centrando-se principalmente na que o autor caracteriza como "mujeres fuertes" desse livro de Saer, usando como referências teóricas escritoras e críticas literárias feministas, em especial, Virgínia Woolf e Simone de Bouvoir.
} 
socialmente secundarias" (p. 111).

Por sua vez, em El río sin orillas. Tratado imaginario (1991), ensaio longo em que se reflete sobre características da sociedade argentina, Saer enfatiza que essa comida é uma forma de expressão da tradição nacional:

A pesar de su carácter rudimentario, casi salvaje, el asado es rito y promesa, y su esencia mística se pone en evidencia porque le da a los hombres que se reúnen para prepararlo y comerlo en compañía, la ilusión de una coincidencia profunda con el lugar en el que viven (2012).

La Grande - romance inacabado do autor, publicado postumamente em 2005 - tem um tempo cronológico de sete dias. Nos cinco primeiros, Gutiérrez, o protagonista, organiza um "asado" e convida amigos que reencontra depois de trinta anos de ter deixado a "zona". O sexto, um domingo, é inteiramente dedicado à narração da festa. Do sétimo dia, uma segunda-feira, só há uma frase: “con la lluvia llegó el otoño, y con el otoño el tiempo del vino" (2017). A carne e o vinho são abundantes e, em contraste, as saladas são mais frugais, o que leva um convidado a perceber no anfitrião um desejo purista de conservar o "asado" de contaminações, mantendo o seu caráter ritualístico:

[...] de golpe comprende que se trata de una suerte de purismo conservador por parte de Gutiérrez, un purismo libresco del que hasta las dos ensaladas clásicas pueden parecer una concesión, porque la plétora colorida de ensaladas diversas es una exageración urbana, que traiciona el ascetismo rural originario del asado (2017, grifo nosso).

Portanto, nos textos mencionados acima, o "asado", como parte de um passado patriarcal argentino e como expressão fundamental de sociabilidade nacional é predominantemente masculino, assim como as relações de amizade na narrativa saeriana. Por sua vez, a montagem das saladas corresponde às mulheres, que só podem acompanhar os homens, mas não protagonizar a comida ou a narrativa, assim como a salada é secundária à carne. Portanto, o purismo clássico de Guitiérrez, apesar do narrador ressaltar um lado paródico, é uma afirmação da virilidade do "asado" e de pertencimento cultural, ao qual o protagonista se agarra como um meio de tentar viver uma experiência perdida na sua juventude ${ }^{27}$.

\footnotetext{
${ }^{27}$ Dalmaroni e Merbilhaá (1999) sustentam que a memória em Saer está à sombra de Proust, argumentando que a sua narrativa discute e inverte o projeto de Em busca do tempo perdido, o qual é baseado na possibilidade de narrar a partir da memória que sobrevém involuntária, mas efetivamente. Ao citar alguns textos de Saer, entre
} 
Em Glosa, as personagens mulheres também ocupam um papel secundário. Entretanto, não se pode deixar de ressaltar que se conta no romance a amizade entre Rita e Hector, dois pintores que possuem diferentes técnicas de pintura e visões de arte díspares, mas que nem por isso deixam de nutrir um respeito e amizade mútuos, o que reforça que essa relação ocorre entre personagens construídos como heterogêneos entre si. E ela, apesar de ser retratada vulgarmente como uma pessoa que "cuando tiene unas copas encima quiere mostrarle las tetas a todo el mundo" (2013, p. 183), é reconhecida como uma artista de talento que leva Leto e Matemático a compartilharem uma experiência estética quando vislumbram um de seus quadros exposto em uma vitrine, como se mencionou na primeira parte.

Voltando a El río sin orillas, Juan José Sar frisa o seguinte: "un asado no es únicamente la carne que se come, sino también el lugar donde se la come, la ocasión, la ceremonia. Además de ser un rito de evocación del pasado, es [principalmente] una promesa de reencuentro y de comunión" (2012, grifo nosso).

Comer junto gera comunidade. O prazer que a comida proporciona se desdobra, se intensifica no prazer de interagir, de conversar. Em Glosa, a narração das lembranças do "asado" que proporcionou reencontros e comunhões começa desde a evocação dos seus preparativos. Na versão de Matemático, de acordo com Botón, aconteceu o seguinte: Gato convidou Botón para o aniversário de Washington; o segundo se esqueceu de levar o seu violão, mas levou garrafas de vinho branco; o aniversariante e os convidados chegavam gradualmente ao local da celebração; enquanto um convidado instalava um barril de cerveja, outros preparavam a mesa em um "quincho" (cobertura de palha) ao lado de uma "parrilla" (churrasqueira) que assava peixes levados por outro convidado, etc. Pouco a pouco, a festa e os convidados vão ganhando uma forma para Leto e o leitor, por mais que essa recepção seja intermitente, fragmentária e contraditória, como se mostrou na parte anterior e como se vê claramente no seguinte fragmento:

la imagen fragmentaria, intermitente, confusa por momentos, que el relato genera en él [Leto] y que, de modo paradójico, ¿no?, a causa de su fragmentariedad y también de su carácter no empírico semejante al de las historias fabulosas, va dejando rastros profundos y vivos en su memoria: la quinta de Basso, Silvia Cohen, más inteligente que su marido, la mesa bajo el quincho y la discusión, Beatriz armando un cigarrillo, la balsa a Paraná, los silencios socarrones de Washington, la mujer de Pirulo desangrándose con la jeringa, los tres mosquitos de Washington que, diminutos y

eles Glosa, os críticos concluem que não há memória involuntária, mas existe a percepção involuntária do experimentado. Essa pressupõe um esforço por parte do sujeito, mas é involuntária porque o resultado negativo produz um encontro inesperado entre percepção individual e mundo. 
grises, empiezan a revolotear en la noche de verano, en el estudio iluminado, en Rincón Norte, zumbando nítidos, el caballo de Noca tropezando en un campo de la costa constituido por un término medio de campos de la costa ya visitados y transferidos a lo Anterior - todo eso, ¿no?, mezclando además, y sin elaboración cuidadosa, las afirmaciones contradictorias de Tomatis y del Matemático (2013, p.192).

Além disso, como se mencionou várias vezes, o "asado" é um dom em si. A festa de aniversário é oferecida para Washington Noriega pelos seus amigos, único grupo representado na celebração. Matemático conta, a partir da versão de Botón, que o aniversariante não teve que contribuir com os gastos ou preparativos da festa. Esses foram divididos, como se viu mais acima, entre os presentes na celebração. Portanto, o evento em si é uma demonstração de amizade para o aniversariante.

Depois de armado o contexto preliminar ao evento, Matemático conta o que Botón relatou do início de um absurdo debate sobre o tropeço de cavalos ao redor de uma "parrilla":

Según parece, dice el Matemático, Noca le dijo a Basso que llegaba tarde porque uno de sus caballos había tropezado y se había quebrado una pata. Estaban [...] cinco o seis alrededor de Cohen, masticando cubitos de mortadela y tomando cerveza como aperitivo, y observando a Cohen que manipulaba brasas y leña, no sin hacer toda clase de muecas y lagrimear entre el calor y el humo del que los espectadores se mantenían a distancia confortable. Y cuando, según Botón, Basso había comentado la excusa de Noca, Cohen había interrumpido bruscamente su trabajo y, sin dejar de lagrimear y de hacer muecas dolorosas, se había plantado, perentorio, frente a Basso: ¿Desde cuándo los caballos tropiezan? (2013, p. 46, grifos do autor).

Quando Sarlo (2016) analisa conversas à mesa semelhantes em La Pesquisa, outro romance de Juan José Saer, ressalta que os três amigos que conversam comendo e bebendo cerveja em um bar são apresentados como inteligentes, mas que não procuram debater ideias que pressuponham uma cultura livresca. No caso de Glosa, há também um desinteresse em representar personagens que conversam sobre algo edificante de maneira séria e/ou sólida.

De acordo com Mikhail Bakthin (1987) em “O Banquete em Rabelais", as conversas à mesa nas festas populares eliminam distâncias hierárquicas ao misturar livremente o profano e o sagrado, o superior e o inferior, o espiritual e o material. Portanto, não há incompatibilidades nessas celebrações. Tal mescla de elementos aparentemente incompatíveis 
acontece em Glosa, o que desconcertou a tradutora do romance para o francês, segundo Saer em uma entrevista ${ }^{28}$ :

[...] el lenguaje coloquial y el lenguaje filosófico pueden ser una buena combinación estilística, un cocktail estilístico interesante. Sobre eso, una anécdota significativa. Las traducciones de Laure Bataillon siempre fueron impecables. Cuando empezó a traducir Glosa vino un día y me mostró un par de páginas. Estaba muy desorientada. Eran un desastre esas dos páginas, no correspondían nada con el texto. [...] Vino entonces y me empezó a preguntar palabra por palabra, cuando tenía dudas, sobre la extracción de la palabra, si era popular, si era coloquial [...] En Glosa, está muy presente esa mezcla de lenguaje coloquial, de lenguaje popular, de lenguaje culto y filosófico (p. 220).

A associação entre o debate e o "asado" proporciona conversas livres do peso da seriedade. $\mathrm{O}$ bom humor que o encontro entre amigos causa está principalmente em um excessivo interesse que a rede tem em conversar longa e seriamente sobre assuntos banais como cavalos, mosquitos ou uma simples festa de aniversário.

Em vista disso, podemos fazer uma nova comparação por diferença com O Banquete. De acordo com Pinheiro (2011) na introdução a uma edição desse diálogo platônico, o texto filosófico em questão é um concerto de múltiplas vozes em que há uma disputa de oradores representantes dos gêneros literários vigentes na época: o retórico, o científico, o cômico, o trágico e o filosófico. Essa disputa é semelhante ao que acontece na festa e, em certa medida, na caminhada em Glosa. Entretanto, ao contrário do diálogo platônico, o romance não tem como finalidade a busca de uma verdade transcendente, mas sim o debate sobre assuntos banais para a diversão dos amigos, tal como se observou anteriormente e como afirma o próprio autor na mesma supracitada entrevista quando perguntado de onde saiu a ideia dos "mosquitos de Washington":

Los mosquitos salieron del hecho de que Platón en El Banquete se ocupa de un tema universal, importante, que es el amor. Yo pensaba que ahí [em Glosa] tenía que ser una cosa mucho menos significativa, [...] Como [o mosquito] es un elemento frecuente [...] en Santa Fe, la cosa más banal, puede ser el tema (p. 218).

O afirmado acima também tem a ver com o que o escritor chama de irresponsabilidade

\footnotetext{
${ }^{28}$ SAER, Juan José; PREMAT et. al. “Entrevista a Juan José Saer el 4 de marzo de 2005”. In: PRIETO, Martín (comp.) Juan José Saer: una forma más real que la del mundo. Buenos Aires:Mansalva, 2016.
} 
filosófica da literatura em outra entrevista ${ }^{29}$ :

Yo creo que la literatura tiene una responsabilidad estética pero una suerte de irresponsabilidad filosófica. A causa de sus debates con la ciencia hay ciertas cosas de las que la filosofía ya no puede hacerse cargo. Entonces la literatura puede tomarlas porque no tiene ningún tipo de responsabilidad conceptual o sobre todo metodológica (p. 93-94).

Como mencionado na parte anterior, o Washington da versão de Tomatis mostraria com sua absurda história sobre os mosquitos o ridiculamente delirante que é discutir longa e intensamente sobre o tropeço de um cavalo:

[...] como se habían puesto a delirar sobre un caballo por qué no deliraban ya que estaban sobre tres mosquitos, de manera tal que, puesto que se les había dado por delirar, deliraran en serio, no a costa de un pobre caballo sobrecargado desde el vamos de delirio insensato por la especie humana, sino, si eran capaces, y ya que tanto les gustaba delirar, de tres mosquitos, grises, diminutos y neutros, un modo elegante de sugerirles que, cuanto más irrisorio es el objeto, más claro resulta el tamaño del delirio (2013, p. 122).

Filosofar irresponsavelmente é delirante e, por isso, risível. Isso ocorre pela possibilidade de rir com e dos amigos nessas celebrações.

Por sua vez, na caminhada, Leto, intencionalmente, dá um sentido mais elevado a um cumprimento de Tomatis quando se encontram na caminhada:

[Tomatis] se vuelve hacia Leto-: ¿Cómo va la cosa?

- La cosa bien. Yo más o menos - dice Leto.

Tomatis se echa a reír.

—Qué humor tan fino — dice (2013, p. 107).

De acordo com Ricci (2009), quando Leto responde "La cosa bien. Yo más o menos", o protagonista evidencia fugazmente uma amizade com Tomatis porque compartilham uma linguagem, comum nas relações entre os personagens centrais da narrativa saeriana como um todo. O chiste causa o riso cúmplice de Tomatis e merece seu elogio pelo "humor tan fino" de Leto. Ou seja, o sorriso é provocado porque dá um sentido elevado a uma palavra de uma saudação corriqueira. Portanto, essa transformação é intencionalmente cômica, assim como

\footnotetext{
${ }^{29}$ SAER, Juan José;POMERANIEC, Hinde. "Un paso de comedia negra”. In: PRIETO, Martín (comp.) Juan José Saer: una forma más real que la del mundo. Buenos Aires: Mansalva, 2016.
} 
pode ter sido o longo debate pretensamente sério/filosófico sobre cavalos, mosquitos, o instinto animal ou o comportamento imprevisível dos seres vivos.

$\mathrm{O}$ crítico acima ressalta que Leto usa a linguagem que compartilha com esse amigo para transformar essa "cosa” coloquial de uma simples saudação como “¿cómo va la cosa?” em um ente quase filosófico do qual seu "eu" estaria à margem. Essa distância do ser e da coisa como abstração do mundo real traz a essa cena aparentemente nímia uma das preocupações mais importantes da narrativa saeriana como um todo: a cisão entre sujeito e mundo.

Outros discursos sérios são comicamente rebaixados e ironizados também desde a sua dedicatória. $\mathrm{Na}$ quarta linha desse paratexto, o romancista atribui aos destinatários três ciências adjetivadas como verdadeiras, qualificação que tem um tom levemente irônico. Ricci (2009) observa que as últimas três linhas incorporam o autor usando essa palavra em um contexto de ironia e pouca solenidade, posteriormente localizado na cena de amizade compartilhada ("las sobremesas de domingo"). Em "Gag", Alan Pauls (2010) argumenta que essa situação possui um tom ironicamente cerimonioso, associando-o ao caráter ritualístico e de doação de comida presente nos autores espanhóis do século XVII que ofereciam suas obras aos benfeitores que possibilitaram a sua feitura. Sobre tal oferecimento, Ricci (2009) observa que os amigos são os destinatários primeiros e definitivos da literatura, tanto nas dedicatórias, como no interior da narrativa saeriana.

Na caminhada, Tomatis ridiculariza o discurso cientificista de Matemático. Segundo Julio Premat (2002), a misantropia e melancolia desse personagem o levam a uma ofensiva contra os cientistas que, além de ilustrar os exageros e arbitrariedades desse personagem, transmitem uma visão da ciência que corresponde à incredulidade generalizada que domina o romance:

\footnotetext{
¿Científicos? repite casi gritando Tomatis. Y después, de esta manera: mercachifles a sueldo de la policía más bien, que pretenden conocer lo que ellos llaman realidad porque creen saber que lo que han decidido sin consultar a nadie que son plantas necesitan efectuar algo a lo que le han puesto el nombre arbitrario de fotosíntesis para lo que ellos dicen que es crecer (2013, p. 109-110, grifo do autor).
}

Por sua vez, passando do nível da narrativa para o nível da narração, o cômico da voz narradora está em enfatizar a sua não autoridade, a sua incapacidade de dominar completamente o que conta. As correções bruscas e desdenhosas em torno do que os 
personagens pensam e nas especulações sobre suas mínimas ações levam Lucero e Balderston (2010) a concluir que o humor do narrador incita o riso no leitor por ser uma paródia da onisciência narrativa, já que esse narrador se preocupa exageradamente em dar conta de detalhes, de erros e de incongruências por meio de um olhar tortuoso e brincalhão. Sendo assim, os críticos vêem - e nós com eles - o romance como uma brincadeira, pois o tom comicamente dubitativo da narração, assim como as glosas da festa e os debates entre os personagens-amigos, não pretende esclarecer, mas desconcertar o leitor com inesgotáveis reformulações e questionamentos, mostrando o lado risível das preocupações do narrador e dos personagens. Portanto, mais uma vez, frisamos que a voz narradora estabelece com o leitor uma cumplicidade semelhante a das relações de amizade entre os personagens.

Por isso, a leitura nos levou a tomar, assim como Leto, "con pinzas" as versões da festa, explicitando-as e confrontando-as. Sendo assim, analisemos novamente a versão de Tomatis. Nesse caso, o seu humor é destrutivo porque quer dar peso à leveza da celebração. Os convidados que eram "gente tan diversa", amigos das mais diversas origens e idades do aniversariante na versão de Matemático-Botón, são um "rejuntado de borrachones, pistoleros y cabareteras" (2013, p. 113) na perspectiva de Tomatis.

Um pouco mais adiante, desqualifica a capacidade intelectual dos amigos que debatem: "Y Tomatis sacude la cabeza, agobiado por la cantidad de invitados al cumpleaños de Washington incapaces de estar a la altura de la discusión" (2013, p. 121). Por isso que Matemático se atém à mais leve versão de Botón, contestando a versão de Tomatis desde quando está escutando-a:

\footnotetext{
¿Y él, Tomatis? Como si hubiese adivinado la interrogación mental del Matemático, Tomatis continúa, refiriéndose justo a su propia persona: él no intervino para nada, todo ese despliegue inútil de supuesta dialéctica tenía la capacidad de hincharlo soberanamente, así que se limitó a quedarse mudo en la punta de la mesa comiendo lo más tranquilo su amarillo y tomando piola su vino blanco — lo cual, si el Matemático se atiene a la versión de Botón, sería más bien falso, puesto que, según Botón, Tomatis, por cuyas arterias ya circulaban, desde antes de llegar a la fiesta con Barco y las chicas, tres o cuatro whiskies, si bien es cierto que no intervino de modo directo en la discusión, se la pasó todo el tiempo hostigando a unos y a otros, ridiculizando con juegos de palabras de segundo orden las diferentes intervenciones y reduciendo al absurdo, por pura volubilidad, la mayor parte de los argumentos (2013, p. 121, grifo nosso).
}

Curioso que na versão de Botón é Tomatis, e não Washington, que apontou o absurdo da discussão entre os amigos. Entretanto, esse personagem não está com o mesmo humor 
corrosivo apresentado na caminhada: o tom brincalhão não é destrutivo, mas sim leve, volúvel.

No presente prazeirosamente dilatado desses encontros, os amigos estão obcecados pela vida e pelas experiências sensoriais que a festa lhes proporciona e, como se viu até agora, a discussão está ligada a esse contexto. Por exemplo, segundo a versão de Matemático-Botón, no fim da celebração:

[...] después de la noche que habían pasado, del alcohol y de la amanecida, de los toqueteos carnales y fugaces en los márgenes oscuros de la reunión, de la excitación de las discusiones, habían salido a la mañana gélida dichosos y reconciliados con el todo y deseaban, porque el olvido de sí actualizaba la esperanza, que esas ondas benévolas que los mecían se verificaran, incontrovertibles, en lo exterior (2013, p. 139).

No trecho acima, os cinco sentidos se mesclam sem uma hierarquia de valor, apesar dos sentidos mais explorados no romance serem a visão e a audição. Segundo Omar Corrado (1996), em "Sonido, tiempo, forma: Una escucha musical de los textos de Juan José Saer", uma sonoridade recorrente na narrativa saeriana é a que produz as refeições. O autor dá como exemplo o seguinte trecho de Glosa: "Debe haber habido una gritería general antes de pasar a la mesa; idas y venidas a la cocina, sillas que se arrastran; tintineos de platos, de cubiertos, vacilaciones" (2013, p. 62).

O principal sinal e som de felicidade nas reuniões entre amigos é o riso. Esse é constantemente causado pelas brincadeiras de Tomatis:

Según Botón, de Noca, cuando se había armado la discusión sobre el caballo que tropezaba, Tomatis había dicho: Si el caballo iba hacia el boliche cuando tropezó, la culpa es del caballo; si volvía, la culpa es de Noca. Todos se reían (2013, p. 57, grifo do autor).

O riso também irrompe na caminhada. Por exemplo:

\footnotetext{
El Matemático se echa a reír. [...] Leto también se ríe, sacudiendo la cabeza. La risa, que expelen gargantas humanas y que chispea, al mismo tiempo, en ojos humanos, sale al aire tibio del exterior. Un peatón que los cruza, un hombre en mangas de camisa que lleva un portafolios bajo el brazo, cuarentón regordete y casi calvo, se ríe a su vez, sin que ellos lo adviertan, contagiado por la eclosión de risa súbita que acaba de presenciar (2013, p. 41).
}

Os caminhantes compartilham o ato de rir e contagiam quem está ao seu redor. 
Sendo assim, além do humor rebaixar discursos de autoridade, manter os ouvintes atentos às ambigüidades e suscitar prazer, outro dos seus principais efeitos é evidenciar a cumplicidade entre os amigos. Ou seja, essa rede se comunica também por meio dos seus corpos, na materialidade do riso dessas discórdias felizes que são essas reuniões.

Amigos rivais riem uns das opiniões dos outros para intercambiar a experiência de uma amizade que não elimina, mas estimula o conflito que mantém a liberdade de brincar e conversar, sem com isso abrir mão de seus próprios pontos de vista.

Dessa maneira, os sentidos do riso estão restritos ao grupo ${ }^{30}$. Em um diálogo com Ricardo Piglia ${ }^{31}$, Juan José Saer comenta:

En el habla también hay lenguajes privados. Jergas de grupos, jergas familiares que solo entienden los miembros de una familia por experiencias comunes. Creo que en el gran sistema social que es el lenguaje hay toda una serie de islas de lenguaje privado de todo tipo. No solamente las jergas técnicas y profesionales $(1995$, p. 70 , grifo nosso).

Portanto, tal como sugere Jorge Bracamonte (2007), o romance é um esforço de tradução, de "glosa" de certos dialetos sociais ${ }^{32}$ - nesse caso, da rede de amigos - para uma linguagem que tenta explicá-los, tornando-os mais compreensíveis. Por exemplo, quando Matemático refuta a versão de Tomatis, o primeiro considera necessário explicar a Leto - que não está há muito tempo na cidade e conhece pouco ou nada dos convidados da celebração - a impassibilidade de Washington frente a um debate entre amigos. Essa é uma "broma clásica" que ele só faz com quem já o conhece porque esse silêncio bem-humorado poderia ser interpretado como orgulho ou agressão fora do seu círculo de amigos, o qual entende a brincadeira como um prelúdio a sua interferência nas discussões. Sendo assim, apenas o grupo entende o humor de Washington por ser parte de uma linguagem grupal que, por sua vez, é traduzida ao recém-chegado por um dos membros da rede. Entretanto, Matemático atenta para o silêncio bem-humorado de Washington e não para a ambiguidade do seu discurso. Isso

\footnotetext{
${ }^{30}$ Cf. BERGSON, Henri. O riso: Ensaio sobre a significação da comicidade. São Paulo: Martins Fontes, 2007. Nesse livro, o filósofo afirma que as causas do riso repercutem e possuem sentido no círculo fechado de um grupo.

${ }^{31}$ SAER, Juan José; PIGLIA, Ricardo. Diálogo. Santa Fe: Centro de Publicaciones Universidad Nacional del Litoral, 1995.

${ }^{32}$ Natalia Ginzburg (2009) chama essa linguagem comum de léxico familiar, título do seu livro autobiográfico. Nesse, a escritora narra as memórias de infância e juventude em convivência com uma família em meio ao fascismo italiano e à Segunda Guerra Mundial através da evocação de expressões recorrentes da linguagem de grupo.
} 
ocorre porque escolhe levar "en serio" o discurso do aniversariante sobre mosquitos, visto que tende a entender, segundo Tomatis, ao "pie de la letra" o que se discute nesses encontros. Sendo assim, essa atitude dubitativa não parece ser tão desenvolvida em Matemático, pois a sua visão rigorosa/cientificista da vida não permite que o personagem aceite bem a ambiguidade sem escolher a interpretação que mais lhe convém.

O clima da festa também contamina os caminhantes, o que nos leva a perceber que o passeio tem um caráter celebratório, por mais que a comida - elemento fundamental do aniversário - esteja ausente. De acordo com Sandra Contreras (1991), em “Glosa, un atisbo de fiesta", o riso ocorre no passeio porque a narração detida da festa pelos caminhantes prolonga a experiência de um instante alegre, um "atisbo de fiesta", no ato de lembrá-la conjuntamente. Além do mais, há momentos fugazes de coincidência entre os protagonistas e o mundo que está a sua volta. No trecho seguinte, a harmonia dos corpos de Leto e Matemático tem um elemento lúdico:

[...] el Matemático [...] hace girar la cabeza, sin modificar en nada el ritmo de su marcha, y se pone a mirar, por encima del hombro izquierdo, la calle que han venido dejando atrás. Leto que, tenso y vigilante, observa todos sus gestos por el rabillo [...] del ojo, esboza una sonrisa rígida cuando percibe el giro de la cabeza y, muy despacio, como si se tratase de algo milimétrico y ritual, realiza el mismo movimiento. El Matemático, que lo advierte a su vez, espera unos segundos durante los que efectúan dos o tres pasos y, para tomar a Leto desprevenido y hacerlo vacilar, continúa con el cuerpo entero el giro que acaba de hacer únicamente con la cabeza, sin interrumpir la marcha, de modo que ahora todo su cuerpo está de frente a la porción de la calle que han venido recorriendo y el Matemático prosigue como si nada, pero caminando para atrás. Leto efectúa, con una fracción de segundo de diferencia, el mismo movimiento satisfecho de su adaptación rápida al capricho inexplicable del Matemático. Erguidos y más tiesos todavía a causa de lo antinatural de su desplazamiento, reculando con ritmo y precaución, llegan, sin darse cuenta, a la bocacalle, subestimando el revuelo que su actitud singular va levantando en la gente que los cruza (2013, p. 159).

Acima, o narrador conta com detalhes o movimento dos corpos dos personagens, o que mostra mais uma vez que, assim como Matemático se detém e confronta cada detalhe das versões da festa a que tem acesso, a voz que narra a sua caminhada com Leto dilata a experiência de instantes prazerosos.

A partilha das lembranças alheias da celebração também possibilita a interferência nos debates, em retrospectiva, como no fragmento que segue:

Y cuando, según Botón, Basso había comentado la excusa de Noca [...] se había plantado, perentorio, frente a Basso: ¿Desde cuándo los caballos tropiezan?, habia 
dicho.

— ¿Cómo? ¿No tropiezan? — dice Leto.

- Tropiezan. Tropiezan — dice, conciliador, el Matemático. Y después de una pausa dubitativa-: En fin, depende.

— ¿Depende de qué? - dice Leto.

-Depende de lo que se entienda por tropezar (p. 46, grifos do autor).

Além do mais, Matemático começa a divergir da versão mítica de Botón por meio da desconfiança em relação à procedência dos peixes que esse mesmo Noca levou à festa.

Contreras (1991) observa que Matemático insiste em capturar a palavra mais insignificante, o tom mais sutil da discussão daquela noite e o modo evasivo de vozes familiares para poder aprová-las, contestá-las, rebatê-las. Entrar nos diálogos da celebração faz com que a festa e o seu clima celebratório se prolonguem de modo que alguma vez algo dela lhe pertença.

Sendo assim, além do humor evidenciar o caráter de gozo dos diálogos na festa e na caminhada, o próprio ato de conversar despretensiosamente causa satisfação: discordar por discordar, ser do contra é por si só divertido. No prólogo ao livro Tres propuestas para el próximo milenio (y cinco dificultades), Piglia (2001) nega que a conversa se define pelos seus temas, mas sim por uma cumplicidade que a faz possível. Sobre a conversa argentina, o que Saer (re)cria em sua narrativa, sustenta que o diálogo surge do encontro de forças distintas, do cruzamento de dois monólogos que falam e alucinam sobre um tema comum. No caso de Glosa, as conversas veiculam pontos de vista distintos que não visam a concórdia entre os envolvidos, mas o contato entre os membros da rede de amigos.

Os amigos excitados pelo álcool e pela festa, de acordo com o aniversariante na versão de Botón-Matemático, provavelmente possuem a atitude que o narrador externo à narrativa atribui a Hector, um convidado tardio, segundo esse mesmo ponto de vista: "escucho, escucho, pero de todos modos, digas lo que digas, ya tengo preparada la refutación” (2013, p. 192, grifo do autor). Portanto, os amigos não buscam somente o que os une como comunidade, mas também o que os diferencia, o que torna possível a convivência de diferentes pontos de vista que explicitam, que potencializam as suas divergências.

Rir com e às custas do outro é o principal objetivo desse combate de inteligências carregado de ironia e uma das principais demonstrações de afeto das relações de amizade nesse romance em que os personagens fazem parte de uma classe média intelectual argentina e que, de certa forma, parece ser uma (re)criação da maneira que o autor enxergava o seu 
grupo de amigos da juventude. No mesmo diálogo com Piglia a que nos referimos antes, Juan José Saer ressalta o seguinte: "En nuestra vida, en nuestro grupo de amigos, el humor ha tenido siempre un papel importante en la manera de relacionarnos. En el fondo puede ser una especie de pudor, una muestra de afecto o de emotividad [...] indirecta" (p. 84). Sendo assim, o humor que contraria e relativiza ideias é também uma demonstração de afeto, pois é parte importante da conversa entre amigos.

As celebrações entre amigos são momentos em que a vida grupal se tornou leve e fugazmente mais intensa, pois envolvem as sensações dos personagens e intensificam as suas relações. Sobre a comida, Bakthin (1987) alega o seguinte:

Tristeza e comida são incompatíveis [...] Uma refeição [festiva] não poderia ser triste. $O$ banquete celebra sempre a vitória, é uma propriedade característica da sua natureza. O triunfo do banquete é universal, é o triunfo da vida sobre a morte nesse aspecto, é o equivalente da concepção e do renascimento (p. 247, grifos do autor).

Em Glosa, os protagonistas evocam uma celebração que comemora os 65 anos de vida de Washington Noriega, mais um ano em que triunfa sobre a morte. A amizade não é somente um meio para conseguir prazer, mas o que os amigos buscam nesses encontros para que continuem a co-existir nesse grupo. Por exemplo, os pensamentos melancólicos de Leto sobre as consequências do suicídio do seu pai não lhe impedem de viver a alegria de estar com alguém que co-existe no seu círculo de amigos. A comunidade se constrói e se reconstrói em ocasiões, eventos de curto espaço de tempo, mas são nesses instantes que as relações de amizade são mais importantes.

Esses encontros não têm uma finalidade prática. De acordo com Agamben (2011) em "Un hambre de buey", a festa na sociedade moderna não é descanso, não é fazer nada. Celebrar consiste em viver de outra maneira, divertindo-se, desviando-se, suspendendo, tal como o dom em Derrida, a economia, a utilidade das atividades cotidianas. Sendo assim, esse evento não se define pelo que os participantes fazem, mas sim pelo que transformam em inoperante, ideia estreitamente relacionada à "potência de não", do mesmo autor:

Si comemos, no lo hacemos para asimilar la comida; si nos vestimos, no lo hacemos para cubrirnos o resguardarnos del frío; si nos mantenemos despiertos, no lo hacemos para trabajar; si caminamos, no es para ir a alguna parte; si hablamos, no es para comunicarnos informaciones; si intercambiamos objetos, no es para vender o comprar (AGAMBEN, 2011, p. 162-163). 
Ou seja, os convidados suspendem a finalidade, a utilidade de suas ações nesses eventos, se divertem porque, entre outras coisas, se desviam da normalidade da rotina diária. A festa é gratuita e, por isso, uma forma de doação que desperdiça tempo entre amigos. Segundo Derrida (1995), o dom da amizade é o gasto em pura perda, em um prazer auto-afetivo. Em Glosa, os participantes comem para compartilhar e celebrar, e não para se saciar; permanecem acordados até a entrada da madrugada, segundo as versões de Botón-Matemático e Pichón, para que a festa dure; etc. Por sua vez, Leto e Matemático também transformam a caminhada em inoperante, e esse passeio sem destino favoreceu um imprevisível e temporário vínculo afetivo mais intenso entre os dois, além de viverem a celebração por meio das versões. Ademais, o humor do narrador e dos personagens, no nível da narração e do enunciado, é uma prática que torna inoperante o discurso filosófico, subvertendo-lhe, dando-lhe outra finalidade que não a busca de uma profunda verdade, mas a de rir e de divertir-se juntos. Por sua vez, no já mencionado "asado" de La Grande, essa sensação se condensa quando o narrador conta, sem qualquer tipo de vacilação, que a vida se torna mais interessante em um alívio passageiro:

\begin{abstract}
Una blanda aceptación mutua, un abandono al instante, les procura un bienestar inesperado, sacándolos del ronroneo interno que llena las horas del día, la rumiación solitaria, autorizándolos a encontrar en el exterior, como un alivio pasajero, una vida interesante y placentera, aunque más no sea que por unos momentos, en un domingo de abril excepcionalmente caluroso que les da la ilusión de estar pasando unas interminables vacaciones (SAER, 2017).
\end{abstract}

Nesse sentido, tal como Johan Huizinga (2014) especula em Homo Ludens, a disposição para o lúdico, como festar ou caminhar sem destino, é um aspecto fundamental da vida humana e da arte, que não está abarcado pela sabedoria do homo sapiens nem pela capacidade de fabricação de instrumentos do homo faber. Portanto, o homo ludens não é o cientista ou o artesão, mas o ser que desperdiça tempo em práticas inúteis, como os amigos em Glosa ou o artista. Sendo assim, como se viu, a rivalidade entre os membros da rede está sob o conceito do lúdico, do jogo. Outro exemplo, o narrador de Glosa dá ao início da narração de Matemático o caráter lúdico do jogo de cartas:

Imaginémonos un jugador que, desde hace un buen rato, tiene en su poder la carta que va a permitirle ganar la partida pero que durante muchas vueltas no puede jugarla porque, de los otros jugadores, ninguna le da la ocasión de hacerlo; durante vueltas y vueltas, el jugador va tirando cartas inútiles, indiferentes, que no cambian para nada el curso de la partida, hasta que, de pronto, la combinación que necesita se forma sobre la mesa, permitiéndole lanzar, con euforia y decisión, 
la carta ganadora. La confesión retraída de Leto ha puesto, al Matemático en esa situación superior (2013, p. 29, grifo nosso).

Conhecer os convidados e o lugar onde se deu o "asado" dá o poder da narração a Matemático e tal poder é comparado à sensação de euforia que a vitória em um jogo provoca no vencedor. A rivalidade entre os amigos, mesmo que incipientes, se evidencia, portanto, desde o início da conversa.

O excesso é outra característica que Agamben (2011) enfatiza sobre a festa como exemplo de lugar de práticas inoperantes e que Derrida (1995) diz ser característica central da experiência doadora. A intensidade no desperdício em instantes prazerosos ocorre porque excede a vida cotidiana, regrada e calculada e não porém, mas por causa de um curto tempo cronológico. Isto é, o dom desses momentos tem que ser aproveitado ao máximo porque é provisório.

Portanto, a festa evocada em Glosa desordena o princípio de ordem do simpósio presente no seu já mencionado intertexto, o diálogo platônico O Banquete. De acordo com Maria J. de Queiroz (1994) em A literatura e o gozo impuro da comida, a prudência e a sobriedade excluem a desordem e a paixão dessas comidas gregas:

\footnotetext{
Nos Symposiaka e no Banquete dos sete sábios, Plutarco discorre, com minúcias, sobre as normas que presidem às refeições. Aprendemos que o jantar propriamente dito [...] não desempenha senão o papel de preparação [...] à bebida. Inicia-se, portanto, pela comida. Em obediência a rituais consagrados, só se começa a beber depois de preces e cânticos e após a deliberação [...] da ordem de apresentação dos oradores e do tema a abordar-se. O simposiarca - presidente do simpósio encarrega-se de dar cumprimento ao programa estabelecido. No modelo do gênero, To symposion, de Platão, cabe a Fedro esse privilégio. No prólogo, Sócrates não só ratifica a delegação, mas expressa o seu voto ao anunciar o tema proposto: 'Comecemos! Desejemos boa sorte a Fedro para abrir o debate e fazer o elogio do Amor!' (p. 31).
}

Entretanto, a autora aponta que Alcibíades, belo jovem que nutre um amor que pensa ser não correspondido por Sócrates, transtorna a ordem inicial, importunando o filósofo por sua falta de pudor e desviando o assunto do debate. No caso do debate de Glosa, não existe um princípio de ordem a ser transtornado porque o prazer que as comidas e conversas entre amigos suscitam é, desde o seu início, antissistêmico.

Esses encontros não são sem medida somente porque em um deles os personagens-amigos debatem sobre assuntos delirantes ao redor de muita comida e bebida excessivamente consumidas ou porque os protagonistas dão demasiada importância a esse 
evento em uma caminhada sem destino. O excesso está também na maneira em que se conta. Como se viu anteriormente, o narrador está desconfiada e obsessivamente atento em relatar um excesso de detalhes que a percepção dos personagens tenta captar. Concordamos com David Oubiña (2005) em "La extenuación" quando sustenta que a narrativa saeriana não avança, não desenvolve uma sucessão de acontecimentos dentro da estrutura progressiva de uma história porque é uma narrativa gerundial, uma prolongação infinita do instante através de um olhar que o esmiúça sem pressa. Portanto, conclui que a descrição nos seus relatos não é instrumento de captura, mas uma operação que testemunha o que o olhar percebe e, logo em seguida, lhe escapa. De maneira semelhante, Sarlo (2016) defende que Saer expande a apreensão da fugacidade da experiência da forma poética haiku usando a frase complexa para captar o banal e fugaz por meio de sua intensidade poética e extensão descritiva com detalhes precisos, dando ao que conta muito mais tempo que o que leva para se executar, o que produz uma experiência do tempo dilatado, do instante como extensão.

Segundo Dalmaroni e Merbilhaá (1999), uma das razões pelas quais a prosa saeriana se associa ao discurso poético é justamente porque a sua obsessão em detalhar a percepção dos personagens na narração mostra o deleite moroso que a materialidade das palavras que constituem a percepção proporciona. A narração morosa põe na mínima velocidade a descrição minuciosa de objetos e atos cotidianos, o que exige um tempo lento de leitura que visa o prazer estético.

Por conseguinte, a narrativa saeriana é texto de fruição. Nesse, segundo Barthes (1987) em O prazer do texto, o fundamental não está na elaboração e resolução de um enredo, mas no que acontece na linguagem a cada trecho. Por isso, textos de fruição idealizam um leitor atento às minúcias, sem pressa ou desejo de chegar ao fim:

Ora, paradoxalmente (a tal ponto a opinião crê que basta ir depressa para não nos aborrecermos), esta [...] leitura [do texto de fruição], aplicada (no sentido próprio), é a que convém ao texto moderno, ao texto-limite. Leiam lentamente, leiam tudo, de um romance de Zola, o livro lhes cairá das mãos; leiam depressa, por fragmentos, um texto moderno, esse texto torna-se opaco, perempto para o nosso prazer (BARTHES, 1987, p. 20).

Em vista disso, assim como Leto e Matemático se demoram na apreciação de um quadro, na escuta de um poema e nas suas elucubrações sobre a festa em que os convidados a viveram intensamente se demorando e alongando-a até a entrada da madrugada em conversas, 
comidas e bebidas, o narrador de Glosa deseja desperdiçar tempo se prolongando no prazer que a sua relação com as palavras lhe dá, palavras que materializam textualmente os pontos de vista dos personagens. Além do mais, a lentidão também é característica no processo da escrita de Em “Saer: um escritor del lugar” (2008), Julio Premat, responsável pela edição crítico-genética de Glosa, nos relata o seguinte sobre os manuscritos do romance:

\begin{abstract}
Saer escribe lentamente a mano, en prolijos cuadernos con renglones y márgenes, sin blancos, sin pausas, sin arrepentimientos. [...] Glosa, por ejemplo, cuya complejidad estilística, cuya trama intrincada de planos temporales, cuya red fluctuante de versiones y personajes, son notables, está escrita así: una palabra después de la otra, de cuadra en cuadra, una página y otra página y por fin tres cuadernos, veintiuna cuadras y un estructura impecable (2008, p. 172, grifo nosso).
\end{abstract}

Oubiña (2005) também ressalta que essas tentativas de captar um instante através de uma decomposição analítica conduzem ao fracasso. Quando isolados, imobilizados e vistos de perto, esses instantes são difusos, opacos. Quanto maior a aproximação e detimento, maior a confusão. A voz narradora sente, ao mesmo tempo, angústia por não conseguir dar conta do que narra e gozo no próprio ato de narrar que nunca cessa de buscar diferentes maneiras de contar minuciosamente a percepção dos personagens. Nesse sentido, Glosa é um tipo de obra inoperosa ou inoperante, definida por Agamben (2017):

\begin{abstract}
A obra inoperosa, que resulta dessa suspensão da potência, expõe no ato a potência que a levou ao ser: se for uma poesia, exporá na poesia a potência da língua; se for uma pintura, exporá sobre a tela a potência do pintar (do olhar); se for uma ação exporá no ato a potência do agir. Só nesse sentido pode-se afirmar que a inoperosidade é poesia da poesia, pintura da pintura, práxis da práxis. Ao tornar inoperosas as obras da língua, da política e da economia, ela mostra o que o corpo humano pode, abrindo-o para um novo uso possível (p. 117-118, grifo nosso).
\end{abstract}

Isto é, a poesia, paradigma da literatura, é desativada de sua função informativa, comunicativa, etc. E por meio dessa inoperância, abre-se possibilidade para outro uso da linguagem, o poético/literário. Portanto, assim como os encontros e as conversas entre amigos, a narração é inoperante porque explicita a sua potência de não comunicar algo definitivo ou eficiente, o que lhe abriu possibilidades de contar desconfiadamente as diferentes versões da festa de uma maneira obsessiva e prazerosa.

Além de inoperantes e excessivas, essas reuniões possuem um sentido incerto em suas conversas e nas diversas maneiras de lembrá-las, como se viu na primeira parte desta 
pesquisa. Assim como nós, em Dar (el) tiempo: la moneda falsa, Derrida (1995) analisa as relações de amizade entre os personagens em uma narrativa de Baudeleire, "La moneda falsa". Em síntese, esse texto conta um passeio em que o narrador e um amigo caminham, conversam e fumam. Em determinado momento, o segundo entregou uma moeda para um mendigo e, posteriormente, confessou à voz narradora que o que havia entregado era dinheiro falso. No entanto, tal como em Glosa, Derrida (1995) destaca que o narrador desse texto enfatiza que não confia, não sabe se o amigo diz a verdade e conclui que "La moneda falsa" é uma construção narrativa enigmática que mostra ao leitor o que permanecerá ilegível, indecifrável. Ou seja, a narração está marcada de tal forma que, assim como o narrador, os leitores só têm a palavra do amigo, confiável ou não. Portanto, o texto é um dom na medida em que sempre se destinaria a alguém, mas é um dom sem crédito, sem valor. Sobre o título, Derrida explica que nunca se dá uma moeda verdadeira, isto é, uma moeda cujos efeitos podem ser calculados, uma moeda/narrativa com a qual se antecipa os acontecimentos que dela se esperam. Ou seja, a moeda falsa, paradigma do dom, é sempre surpreendente, e por extensão, misteriosa.

Em vista disso, as duas narrações, a que Derrida analisa e a que analisamos, são dons sem valor de verdade, assim como a amizade nos dois textos. Em Glosa, as relações entre os personagens, entre os personagens e o narrador e entre o narrador e o leitor, não pressupõem a confiança e, portanto, as mesmas opiniões ou interpretações. Seres unidos não pelas mesmas certezas ou pontos de vista, mas pelas desconfianças e divergências. Sendo assim, essas relações entre os personagens são uma das criadoras de uma narrativa que indaga e explicita seus limites e incapacidades de apreender efetivamente o que se percebe e experimenta. 
- É tudo inútil, se o último porto só pode ser a cidade infernal, que está lá no fundo e que nos suga num vórtice cada vez mais estreito.

$[\ldots]$

- O inferno dos vivos não é algo que será; se existe, é aquele que já está aqui, o inferno no qual vivemos todos os dias, que formamos estando juntos. Existem duas maneiras de não sofrer. A primeira é fácil para a maioria das pessoas: aceitar o inferno e tornar-se parte deste até o ponto de deixar de percebê-lo. A segunda é arriscada e exige atenção e aprendizagem contínuas: tentar saber reconhecer quem e o que, no meio do inferno, não é inferno, e preservá-lo, e abrir espaço (CALVINO, 2017, p. 200).

\section{AMIZADE E POLÍTICA}

\subsection{Leveza}

Como se viu especialmente na primeira parte desta pesquisa, a narrativa de Juan José Saer tem uma forte carga meta-reflexiva porque, entre outros motivos, pensa sobre os seus próprios procedimentos e temas. O escritor reforça isso em seus ensaios. No início da “Explicación” de El concepto de ficción (1997), escreve:

[...] las cosas que pensaba hace treinta años sigo pensándolas, pero puestas todas juntas no constituyen una teoría del relato de ficción, sino más bien una serie de normas personales para ayudarme a escribir alguna narración que justifique tantas páginas borroneadas (p. 07, grifo nosso)

Uma dessas intervenções pessoais que surgem da sua prática de escritor é "La selva espesa de lo real", onde concentra-se em alertar para os perigos de visões de literatura latino-americana vigentes na época - o realismo mágico e a narrativa socialmente engajada - e veementemente negar que tais ideias limitem o fazer literário de um escritor latino-americano.

Em "Las tradiciones literarias latinoamericanas en Saer, Piglia y Aira", artigo em que se discute o debate com as tradições latino-americanas nas intervenções críticas dos três autores mencionados no título, Jorge Bracamonte (2013) conta que a discussão sobre a representação de uma especificidade latino-americana ocorria desde o fim do século XIX, mas possuiu uma especial força na emergência de uma "nueva narrativa latinoamericana" no fenômeno boom, período entre 1955 e 1975. Após esse período, o autor diz que houve uma crise de consenso e um questionamento da especificidade latino-americana, correlatos aos 
fenômenos de neo-conservadorismo ideológico-político-cultural, de neoliberalismo econômico e de regimes ditatoriais que ocuparam quase toda a América Latina.

Muitas das intervenções críticas de Juan José Saer constroem uma figura de autor que desconfia e se preocupa com o atributo latino-americano e, por sua vez, defende uma literatura sem esse atributo e uma crítica que valorize isso. No caso de "La selva espesa de lo real”, põe em cena alertas sobre os perigos da especificidade da literatura latino-americana. Tal ensaio é o primeiro de uma seção que tem por título "Una literatura sin atributos". Essa, segundo o próprio escritor, foi publicada três vezes antes de ser compilada em El concepto de ficción:

La sección llamada "Una literatura sin atributos" es en realidad una recopilación de artículos que aparecieron por primera vez en forma de libro en francés, y que fueron retraducidos al español para una edición de la Universidad Nacional del Litoral. Una edición aumentada [...] de ese libro, a cargo de Hugo Gola, apareció en 1996 en la colección Poesía y poética, de la Universidad Nacional Iberoamericana de Méjico (1997, p. 300).

Portanto, essa seção foi publicada em distintos âmbitos: primeiramente, numa compilação publicada em um meio intelectual francês, posteriormente traduzido para o espanhol e publicada pela editora da Universidad Nacional del Litoral - lugar onde o crítico-escritor foi professor antes da sua radicação na França -, e novamente publicado em meio universitário mexicano graças a Hugo Gola, amigo da juventude de Saer e poeta exilado no México ${ }^{33}$. Finalmente, esses textos são novamente republicados como a seção que fecha $E l$ Concepto de ficción.

No caso de "La selva espesa de lo real", uma informação que não consta no livro de 1997, mas sim na publicação da Universidad Nacional del Litoral, é que o texto foi publicado na revista francesa Magazine Litteraire em setembro de 1979. De qualquer forma, o seu público é, em primeiro lugar, francês e, posteriormente, argentino e mexicano em contextos universitários. Por conseguinte, as reflexões apresentadas são contundentemente contrárias ao que a intelectualidade especialmente francesa está em sua maioria esperando da literatura latino-americana: representar um referencial latino-americano exterior e anterior à própria literatura.

No seguinte trecho, o escritor enuncia uma preocupação com "esa crítica" que se

\footnotetext{
${ }^{33}$ Saer escreve sobre essa amizade em "Hugo Gola", texto presente em Trabajos (2005), outro livro que compila suas intervenções críticas.
} 
importa com uma especificidade nacional da produção literária e oferece como exemplo a sua auto-imagem de escritor:

Ser argentino [...] es un hecho de la realidad ingenuamente concebido que necesita, como todos los demás, un examen minucioso. No escribo para mi pretendida argentinidad, aunque la expectativa de muchos lectores, especialmente no argentinos, se sienta frustrada. No hablo como argentino sino como escritor. La narración no es un documento etnográfico ni un documento sociológico, ni tampoco un término medio individual cuya finalidad sería la de representar a la totalidad de una nacionalidad (1997, p. 268, grifo e sublinhado nossos).

Nesse fragmento anterior e ao longo da maioria dos textos presentes em El concepto de ficción, uma voz discordante se constrói por meio de uma crítica negativa. Antes de qualquer coisa, a imagem que o autor produz para si enfatiza o que o escritor não é: o narrador não escreve para exibir a sua "argentinidad".

Apesar do movimento de refutação do senso comum ser bastante recorrente no discurso argumentativo, as recorrências das negações dão um tom muitas vezes irascível e uma força a essa oposição que desafia e, consequentemente, analisa crenças amplamente aceitas. Visto que o primeiro meio de veiculação desse texto foi uma revista francesa, a primeira armadilha se apresenta como "una confusión y un peligro" de uma tendência da crítica europeia que, partindo de ideias pré-concebidas, confina os escritores no "ghetto de la latinoamericanidad", o que o romancista vê como uma forte relação entre nacionalismo e colonialismo, já que é a crítica europeia que determina o que é ou não é latino-americano.

Continuando a questionar taxativamente essas visões, Juan José Saer identifica e mostra perigos para a literatura latino-americana e, possivelmente, para a sua crítica. $\mathrm{O}$ primeiro e principal deles consiste justamente na ênfase no latino-americano: novamente usando o recurso da negação, o crítico-escritor defende que a função da literatura não é "investigar los diversos aspectos de uma nacionalidad" (1997, p. 269). Para Bracamonte (2013), essa recusa relativiza o valor do latino-americano como questão fundamental para a prática literária, já que no texto em questão Saer situa essa preocupação como secundária ao trabalho do escritor, pois a sua especificidade não provém de um acidente geográfico, seu nascimento, mas sim de um trabalho.

Outro perigo seria o voluntarismo, "consecuencia de nuestra miseria política y social, que considera la literatura como un instrumento inmediato del cambio social" (1997, p. 270, grifo do autor). Isto é, as literaturas que se veem como engajadas não seriam responsáveis por 
mudanças sociais que competem a outras instâncias da sociedade.

Em suma, a selva espessa do real é a ilusão de uma realidade dada e categorizada prévia e exteriormente ao trabalho narrativo. O escritor-narrador deve atravessá-la com uma atitude crítica que exige uma visão que nega o pré-estabelecido, o que, no fim da intervenção, o autor chama de "teoría negativa". A sua preocupação obsessiva com a forma e os alertas anteriores poderiam ser o reflexo de uma posição que defende a exclusão da história e da política de criações literárias. Entretanto, isso não acontece. Bracamonte (2013) demonstra que Juan José Saer reelabora nas suas intervenções críticas e narrativas algumas reflexões de Jorge Luis Borges presentes em "El escritor argentino y la tradición” (1955), principalmente quando se reflete a respeito da influência do latino-americano na escritura. Os dois escritores negam o determinismo e a centralidade do latino-americano/argentino na prática literária, mas não a possibilidade de tratar de todos os temas, inclusive os de procedência das culturas latino-americanas - como, por exemplo, a última ditadura militar argentina ou em tomar como espaço narrativo uma zona argentina - e principalmente seguir, tal como enfatiza Borges no seu ensaio, os "sueños de la creación artística", esses sim fundamentais para toda prática literária.

Inclusive, o escritor de Glosa inclui em Trabajos (2005) um ensaio que intitula "El escritor argentino en su tradición", no qual salienta que a conclusão do ensaio de Borges é correta mas incompleta porque ignora que as transformações locais de um continente, país, cidade ou região definem e redefinem as influências nas práticas artísticas. Por isso, o autor defende que a tradição literária argentina pertence à tradição ocidental porque os escritores argentinos a construíram a partir de uma sucessão de crises econômico-sociais que geram incerteza, violência e ameaça do caos, tornando-os, muitas vezes, matéria de suas poéticas.

Segundo Martín Kohan (2011) em “Glosa, novela política”, a narrativa saeriana desloca-se para uma lógica em que a construção da narração é dominante e não subordinada aos seus temas, como a política que lhe é contemporânea. Por sua vez, Beatriz Sarlo (2016) demonstra que, em Glosa os acontecimentos pertencentes à esfera política no seu sentido mais estrito (e não no mais amplo de que "tudo é político") são ações que responderam a posições ideológicas e a estratégias bem estabelecidas, fatos e práticas inscritos hoje no que pode ser chamado de "história", isto é, configurações do passado que não reverberam nem permanecem ativas no presente, apesar de poderem explicá-lo. Entretanto, quando escreveu o romance, o autor não (r)estabeleceu um cenário histórico, mas sim reconstruiu alguns 
momentos da cena política argentina radical dos anos 60 e 70, longe da pretensão documental, por uma parte, e também de uma reconstrução alegórica, por outra.

A presença do político é direta, mas não pretende fazer nenhum diagnóstico e/ou denúncia do que acontecia na época. Portanto, conclui a autora, o "tema" político não é um cenário, nem um conjunto de ideias, nem sequer uma hipótese sobre o passado, mas sim uma força que pressiona, muitas vezes invisivelmente, o decorrer do relato e de seus personagens.

De fato, tal força está presente em todo o romance, mas incide com uma intensidade diferente nos momentos de vida dos personagens, o que suscita em modos diferentes de narrá-los. O político tem menor potência nos tempos da caminhada e da festa e uma força avassaladora nos saltos para o futuro que o narrador faz para contar o destino de alguns membros dessa sociedade de amigos, em especial, Matemático, Leto e Tomatis.

Sobre a menor potência nos tempos da caminhada e da celebração, o romancista explica em uma entrevista ${ }^{34}$ :

[...] la política está presente todo el tiempo en la novela. Lo que pasa es que [nos anos 60] se estaba en uno de esos períodos calmos, por decirlo de algún modo. En la reunión nunca se dice que quienes participan son de izquierda, pero más de uno se delata como sindicalista (p.119).

Na sua versão venenosa, Tomatis cita Sadi y Miguel Ángel Podio "que se presentan como la vanguardia de la clase obrera" (SAER, 2013, p. 113). Os dois estão ligados ao passado político de Washington, o que mostra que as relações atreladas a essa parte da sua vida não foram completamente cortadas. Portanto, de acordo com Sarlo (2016), os laços políticos atravessam a pequena sociedade de amigos, dando um caráter menos arbitrário ao desenlace das vidas de Leto e Matemático nos anos 80 .

De fato, o passado do aniversariante está muito atravessado pela política no seu sentido estrito. Ainda segundo a crítica acima mencionada, o romance dá pistas políticas para um leitor ideal argentino que, assim como ela, conhece a história recente do país: em 1946, Washington dirigia uma ala de extrema esquerda marxista que aderiu ao peronismo, o que causou repúdio tanto dos seus camaradas menos extremistas como de outros grupos aos quais se uniu mais tarde quando foi acusado de traidor.

Concordamos com Beatriz Sarlo (2016) quando afirma que o desenlace dos episódios

\footnotetext{
${ }^{34}$ SAER, Juan José; BORGES, Ana Inés Larre. "El arte de narrar". In: PRIETO, Martín (comp.) Juan José Saer: una forma más real que la del mundo. Buenos Aires, 2016.
} 
que concernem a Washington tem um exagero cômico. O personagem é internado em um manicômio, seja porque estava verdadeiramente louco ou, segundo a versão que Matemático ouviu, porque não podia entender que as exigências dos peronistas eram impossíveis de se realizar ; ou, como Matemático interpreta, porque outro peronista, amigo de Washington, o internou ali para evitar que seus perseguidores o matassem. Esse homem, Cuello, também esteve na festa, o que indica que ele co-existe na rede de amigos atual de Washington.

No entanto, apesar da ensaísta analisar e refletir sobre os efeitos da política na vida desses personagens, ela não menciona em Zona Saer como as relações de amizade também afetam as experiências políticas representadas. Segundo a interpretação de Matemático das versões que ouviu de alguns membros da rede de amigos que sustentam a hipótese de que Cuello era um amigo, e não um traidor, aconteceu o seguinte:

[...] cuando Washington empezó a recibir visitas en el manicomio [...] el único miembro del partido que aceptaba ver era Cuello. En todo caso, Cuello lo visitaba todas las semanas, llevándole comida, ropa, libros —e incluso, afirma el Matemático, había tenido la delicadeza de frenar la campaña del partido, que acusaba públicamente a la extrema izquierda de haber empujado a Washington a la locura (2013, p.169, grifo nosso).

Política e amizade se entrecruzam, mas a primeira não é o motivo principal da segunda. Por exemplo, depois que Washington sai do manicômio em um estado depressivo, Cuello é, além de ex-companheiro de partido e amigo, um princípio de realidade:

Cuello debe haber sido, más que un apoyo político o afectivo, un criterio de realidad. Cuando no únicamente los otros, sino incluso su propia razón parecía abandonarlo. Cuello se volvió la última referencia, el último puente con el mundo, y como al año, cuando salió del manicomio y pasó por ese período depresivo que le duró hasta fines del cincuenta y uno, Cuello era el único que lo veía y que aceptaba pasar días enteros en Rincón Norte sentado frente a Washington, que no decía una palabra y que sacudía la cabeza de tanto en tanto, emitiendo un suspiro prolongado (2013, p.169).

“Apoyo político o afectivo". Talvez exista uma incompatibilidade entre engajamento político e afeto, amizade. Talvez Cuello salvou Washington justamente porque ele era o seu amigo e não porque concordava com as suas motivações políticas. As conversas cheias de subentendidos entre esses dois, que demonstram uma maior profundidade na relação, só são mencionadas depois que Washington está afastado de suas atividades políticas. De acordo com as versões que Matemático ouviu, o principal agente desse afastamento foi Cuello. 
Por conseguinte, uma leitura crítica interessante para a nossa análise das relações entre política e amizade é a de Martín Kohan (2011) no já mencionado "Glosa, novela política”. Nesse artigo, o crítico sustenta que os personagens, especialmente Leto e Matemático, estão representados entre uma finalidade política e uma finalidade sem fim. Leto caminha sem um objetivo, ao contrário de Matemático que, como se sabe, vai entregar um comunicado do grêmio dos estudantes de engenharia química ao jornal local. Essa diferença de disposição entre os dois personagens mostra que as relações possíveis entre caminhada e narração, entre percurso e escritura, não são necessariamente homogêneas. Há mais de uma caminhada no romance, e há mais de uma maneira de caminhar. A de Leto parece imotivada, resulta de uma espécie de arrebato, não tem outra causa senão uma ocorrência súbita. Matemático, por sua vez, tem um propósito político: ele caminha com um fim determinado, um fim que o expõe à censura e às listas negras. Leto e Matemático são distintos caminhantes, conclui Kohan (2011), mas coincidem logo depois que Matemático faz a entrega do comunicado no diário, quando a motivação política do seu passeio desaparece e ele se deixa contaminar novamente pelo espírito celebratório e sem motivos da conversa e da caminhada com Leto.

Portanto, concordamos quando, em "Uma provável ética na antifesta: união, compromisso e contraponto entre vida, política e narração em Glosa, de Juan José Saer”, Breno A. S. Miranda (2014) frisa que os personagens do romance celebram na festa e na caminhada as trivialidades da vida, sem discussões estritamente políticas:

\footnotetext{
Intelectuais esquerdistas [os personagens de Glosa] encontrar-se-iam não para destilar seus venenos contra a sociedade hipócrita ou defender teses contra o avanço do capitalismo selvagem, muito menos para rezar alguma cartilha de algum marxismo vulgar. (Sim, muitos fazem isso em festas!). Também não arquitetam planos secretos e eficazes de uma tática de guerrilha armada para derrubar o poder. Os [futuros] mártires ou heróis seriam humanizados.
}

Aquilo que realmente preocupa os protagonistas é não haver estado na festa porque a sua ausência desestabiliza a sua sensação de pertença ao grupo de amigos, suscitando um sentimento de exclusão. Ou seja, segundo Beatriz Sarlo (2016), essa sensação relaciona recordações próprias e alheias que, em um primeiro momento, não estariam ligadas. Observemos o seguinte fragmento:

[...] algo [...] iguala [Leto e Matemático] : no únicamente [...] la identidad genérica en tanto que individuos pertenecientes a la misma especie, individuos que [...] hablan el mismo idioma y que aunque vengan de ciudades diferentes han nacido en 
el mismo país e incluso en la misma provincia y poseen por lo tanto fragmentos comunes de experiencia $[\ldots]$ no, $[\ldots]$ sino algo más particular y $[\ldots]$ más indefinido [...] un sentimiento que llevan ambos en el fondo de sí mismos, y que el hecho de ni siquiera sospechar que el otro, u otros, también lo experimentan, le da un tinte particular y [...] lo refuerza, el sentimiento [...] de no pertenecer del todo a este mundo, ni $[. .$.$] a ningún otro, de no poder reducir nunca enteramente lo externo a lo$ interior o viceversa, de que por más esfuerzos que se hagan siempre habrá entre el propio ser y las cosas un divorcio sutil (2013, p. 84-85).

Leto, Matemático e os outros personagens não fazem parte somente de uma sociedade de iguais que compartilham a mesma espécie, o mesmo idioma ou o nascimento na mesma província/país. Mais importante que isso e o que diferencia essa comunidade de amigos é a paradoxal sensação dos protagonistas, e possivelmente dos outros personagens, de não pertencer a esse mundo e a convicção de que esse con-sentimento de deslocamento é particular. Isso ocorre porque o esforço em captar o que lhes é exterior - o mundo e os outros está fadado ao fracasso, demonstrando o divórcio, a separação entre os seres e as coisas. Essa sensação leva Tomatis a compreender o porquê estão entre amigos na festa de La Grande, onde novos e velhos personagens da narrativa saeriana se reúnem ao redor de uma mesa:

De golpe, en un fogonazo de clarividencia, acaba de comprender por qué están todos juntos, reunidos alrededor de esa mesa, distendidos y contentos: porque ninguno entre los presentes, piensa Tomatis, cree que el mundo le pertenece. Todos saben que están a un costado de la muchedumbre humana que tiene la ilusión de saber hacia dónde se dirige y ese desfasaje no los mortifica; al contrario, parece más bien satisfacerlos (SAER,2017).

A compreensão súbita desse personagem que se produz em um outro romance nos serve também para refletir sobre Glosa: os personagens têm consciência de que são deslocados, de que estão à margem do mundo, apesar de que agora essa exclusão é vista com preocupação, o que aparentemente ensombrece o prazer de estar entre amigos.

A nostalgia do que não se viveu no aniversário suscita a acentuação desse sentimento de exclusão que permeia todo o romance e constantemente corta a glosa da festa. Os dois, de acordo com Contreras (1991), não perdem algo que tiveram porque jamais possuíram a festa. Matemático e Leto - um contando a festa e outro compondo as suas visões intermitentes do que poderia ter acontecido - prolongam o evanescente da celebração, a fazem durar não na plenitude do presente, mas sim no tempo impossível e paradoxal da nostalgia, um tempo que convém às conjecturas e aos relatos que insistentemente querem, mas nunca conseguem, recuperar a festa. Por mais que tentem recuperá-la, os protagonistas estarão para sempre 
excluídos desse momento que se prolongará nos relatos das lembranças do círculo de amigos.

Portanto, a força do desejo que os impulsiona a procurar reequilibrar vínculos de amizade pela narração vai de encontro com uma sensação de pertencimento instável a esse mesmo grupo. Para Leto, a sua ausência desestabiliza sua relação com Tomatis e com o círculo de amigos a que recentemente chegou, pois não sabe o motivo de não ter sido convidado: os membros não o chamaram porque não havia necessidade ou porque realmente não queriam a sua presença? Por sua vez, para Matemático, a ausência da reunião da rede de amigos transforma a viagem que realizou pela Europa com um grupo da faculdade de engenharia química menos importante e interessante. Sendo assim, o sentimento de exclusão é reflexo de um temor de não aceitação em um grupo que desejam tanto continuar a co-existir. Os personagens, em especial os protagonistas, tentam superar esse sentimento de exclusão quando buscam o alívio dessa sensação em encontros com amigos.

Entretanto, o sentimento de exclusão e a nostalgia do que não viveram na festa não são, esclarece Contreras (1991), trágicos, mas sim fúteis, leves porque a tristeza da ausência é leve e mesclada à alegria desse passeio. De maneira semelhante, Alan Pauls (2010) aponta sobre os protagonistas:

\footnotetext{
En tanto que excluidos de la región de la experiencia, cuyos resto persiguen y glosan sin pausa mientras caminan [...] el Matemático y Leto tienen tanto derecho a la comedia como esos pícaros subalternos - criados, siervos, esclavos - que en las muestras clásicas del género merodean los palacios donde reinan sus amos, acechan la intimidad de sus señores desde la sombra de las habitaciones de servicios y versionan las intrigas que espían en el idioma bajo y astuto del chiste, el doble sentido, las catástrofes físicas, elementales. Porque la glosa, como la risa, es la revancha del excluido, la segunda oportunidad que el tiempo concede al que se perdió la primera. Golpeado por la melancolía, el que se queda afuera, como el que llega a destiempo, tienen con todo un privilegio extraño, siempre ambivalente: el privilegio de la distancia (p. 819, grifo nosso)
}

Apesar do constante lamento dos protagonistas por sua ausência da festa, de lembranças involuntárias e traumáticas que insistem em voltar às suas consciências, do humor venenoso de Tomatis que corrói parte do passeio e do futuro trágico que os espera, apesar de tudo isso, a caminhada e a celebração evocada são momentos principalmente felizes e, mais tarde, serão lembrados dessa maneira. A melancolia/nostalgia que às vezes domina os protagonistas durante a caminhada é uma tristeza leve ou até cômica, ofuscada pela felicidade de estar juntos caminhando e conversando.

Personagens e narrador evidenciaram um olhar leve sobre o que viveram e narraram 
quando valorizaram esses instantes efêmeros prolongando-os. Em "Leveza", primeira proposta de seu livro Seis propostas para o próximo milênio, Ítalo Calvino (2009) diz que como escritor buscava a leveza como reação ao peso do viver, uma maneira de ver e estar no mundo:

\begin{abstract}
Depois de haver escrito ficção por quarenta anos, de haver explorado vários caminhos e realizado experimentos diversos, chegou o momento de buscar uma definição global de meu trabalho. Gostaria de propor a seguinte: no mais das vezes, minha intervenção se traduziu por uma subtração do peso; esforcei-me por retirar peso, ora às figuras humanas, ora aos corpos celestes, oras às cidades; esforcei-me sobretudo por retirar peso da narrativa e à linguagem (p.15).
\end{abstract}

Como se viu na parte anterior, a leveza se deu em Glosa principalmente por meio, no nível da narração, do narrador que contou detalhada e lentamente momentos de felicidade provisória adiando, dessa maneira, a inevitável dor futura do fim trágico. No nível da representação, a leveza está nos personagens-amigos que riem uns às custas dos outros em conversas que retiram o peso da seriedade dos assuntos que discutem caminhando ou ao redor de uma mesa. Por algumas horas ou minutos, eles se dispõem a resistir aos pesares da existência, porque estão entre amigos.

\title{
3.2 Souvenir
}

No futuro trágico-político dos protagonistas e outros personagens, a alegria, mesmo que não intensa, desses encontros persiste na memória e nos vindouros reencontros do grupo de amigos. Concordamos com Rafael Arce (2013) quando aponta o porquê da introdução da prolepse no romance em "La pasión de lo real":

[...] la prolepsis se introduce porque, cuando Leto finalmente renuncia a comprender el enigma de los mosquitos, el narrador nos dice que esa renuncia no es cierta, porque "dieciséis, diecisiete años más tarde se seguirá acordando de los mosquitos de Washington" [...]. La prolepsis depende de la persistencia del recuerdo: el narrador salta [...] de esa persistencia, de esa retención, hacia adelante (p. 38).

Voltemos para a leitura da quintilha de Tomatis, cena de doação fundamental para a manutenção dos laços entre esse grupo de amigos no futuro desgraçado que os espera.

Como se viu na primeira parte desta pesquisa, Tomatis, Leto e Matemático formam um primeiro circuito reduzido de leitura, con-dividem uma experiência estética e, ao mesmo 
tempo, afetiva nesse momento da caminhada. Tomatis recita a quintilha e percebe a aprovação de Matemático e a distração de Leto. Depois da releitura a pedido do amigo desatento:

— ¿No tenés una copia? — pregunta el Matemático. Tomatis vacila un segundo, y después, desprendido y grandioso, le entrega la hoja al Matemático.

- Intercambio oficial de comunicados entre la Asociación de Estudiantes de Ingeniería Química y Carlos Tomatis — proclama.

—Unos años más, y esto vale millones — dice el Matemático, echándole una mirada admirativa a los versos mecanografiados en el centro de la hoja, y metiéndose la hoja en el bolsillo después de darle un beso ostentoso y de doblarla en cuatro con cuidado y facilidad, siguiendo los dobleces previos hechos por Tomatis (2013, p. 112).

Acima, a resposta a Matemático e o gesto "desprendido y grandioso" em dar a folha com o poema que acabou de ler para um dos dois que o escutou manifestam uma atitude bem humorada de Tomatis. Portanto, mesmo deprimido, ele se deixa contaminar, ainda que temporariamente, pela leveza que é rir com e às custas dos amigos.

No entanto, ao contrário do que Matemático pensa e espera no trecho anterior, o poema ultrapassa a caminhada e passa a ter um significado inesperado e íntimo para esse protagonista. O narrador nos conta que anos depois da caminhada, Matemático continua levando consigo a folha marcada pelo desgaste do tempo e aponta o sentido desse objeto para o personagem:

\footnotetext{
[Matemático] saca la billetera del bolsillo $\mathrm{y}$, de entre los billetes, las tarjetas de crédito, las credenciales, retira la hoja doblada en cuatro que Tomatis le regaló en la puerta del diario [...] Pero el Matemático ni siquiera lee los cinco versos mecanografiados - se limita a recorrerlos con la mirada, ya que la hoja, después de tantos años y de tanto ser transportada, [...] ha perdido ya su carácter de mensaje para volverse objeto $y$, sobre todo, reliquia, a caballo entre su presencia material y, como quien dice, el gran fondo de olvido que tarde o temprano dará cuenta de ella; $\mathrm{o}$ vestigio, más bien, no de Tomatis [...] sino de la mañana en que, acabando de volver de su primer viaje a Europa, se encontró con Leto en la calle principal y caminaron juntos hacia el Sur (2013, p. 125, grifos nossos).
}

O passeio compartilhado que ocupou grande parte do romance se torna uma lembrança conservada em um objeto, relíquia e vestígio. Para nós, é também souvenir. De acordo com Susan Stewart (2013) em El ansia: Narrativas de la miniatura, lo gigantesco, el souvenir y la colección, um objeto se transforma em souvenir quando o indivíduo o conecta a determinado momento de sua vida, tornando material um referente abstrato. Sendo assim, sua função principal é criar um relato contínuo e pessoal do passado.

De maneira racionalmente inexplicável para Matemático, os cinco versos 
datilografados não são somente o souvenir de uma caminhada em uma manhã ensolarada entre amigos incipientes, mas parte de um universo, provavelmente o de sua juventude passada: "la hoja plegada en cuatro estaba en relación secreta con fragmentos heterogéneos del universo, y que si él quería preservarlos de la destrucción no debía desprenderse de ella de ninguna manera" (2013, p. 127,grifo nosso).

Em vista disso, segundo Stewart (2013), o mundo do souvenir é em miniatura porque condensa um universo pessoal e, muitas vezes, é uma alusão material a um passado não mais disponível para os indivíduos - a festa para os convidados presentes - ou que nunca esteve disponível a não ser através de um mundo fictício - a celebração para Leto e Matemático. Portanto, assim como o nome próprio para Derrida (1998) em "El arte de las memorias", Matemático carrega consigo o poema para lembrar-se em um porvir de algo que está ausente.

A marca, a inscrição de um ponto da vida de Matemático como membro da rede de amigos se projeta para a construção de um futuro em que um momento do passado reconstruído na memória sobreviva, ainda que como resto.

Além do mais, apesar de não ser algo com concretude material, a mini-expressão "los mosquitos de Washington" é também um exemplo de vestígio das versões da festa evocadas na caminhada, pelo menos na lembrança dos protagonistas que vivem a celebração através dessas versões, mas criam as suas próprias, como no seguinte trecho:

\footnotetext{
"¡La putísima madre!", piensa Leto. "No largan prenda sobre ese dichoso plano. Mejor. Total, me importa una mierda." Pero no es cierto. La prueba es que dieciséis, diecisiete años más tarde, se seguirá acordando todavía de los mosquitos de Washington.

También el Matemático [...] (2013, p.124).
}

Os objetos e as conversas sobre esse tempo distante quando o narrador salta para o futuro trágico dessa rede de amigos carregam também a nostalgia como sentimento e forma narrativa, mas nesse tempo são predominantes. Segundo Stewart (2013):

\footnotetext{
La nostalgia es una tristeza sin objeto, una tristeza que crea un anhelo que no es necesariamente genuino porque no forma parte de la experiencia vivida. Más bien, se mantiene más allá, antes de esa experiencia. La nostalgia, como cualquier forma narrativa, siempre es ideológica: el pasado que busca no ha existido sino como narrativa, $y$ por lo tanto, siempre ausente, ese pasado amenaza constantemente con reproducirse a sí mismo como el sentimiento de su falta (p. 47, grifo nosso).
}

Vimos que a nostalgia já está presente na caminhada, antes dessa ser condensada em 
um souvenir. Entretanto, esse sentimento é frívolo no presente do passeio. O tempo salta para um futuro de ausências mais graves que a não presença em uma festa. De acordo com Sarlo (2010) em "La política, la devastación”, o sentimento de exclusão compartilhado por esse grupo de amigos se agrava porque as razões das ausências não são mais por uma falta de convite, no caso e Leto, ou por uma viagem pela Europa, no caso de Matemático, mas sim pelo exílio e por mortes.

Assim como a conversa que constrói uma lembrança de uma experiência não vivida para que Leto e Matemático co-existam na rede de amigos por meio do relato, os vestígios e souvenires de lembranças imaginadas e compartilhadas da juventude dos personagens persistem. Além do poema que, como um souvenir, concentra essas recordações, ouvir a expressão "los mosquitos de Washington” reaviva em Matemático lembranças juvenis há muitos anos esquecidas. No seguinte fragmento, a voz narradora nos conta:

Esa expresión, el Matemático la conocía muy bien, pero la dispersión de los últimos años la había relegado un poco, de modo que al oírla, reavivada, igual que el cosmos periódico, gracias a un período de olvido, grandes fragmentos, intactos y claros, de su vida pasada, cobraron, como se dice, actualidad, y el Matemático empezó a evocar, sin proponérselo, recuerdos de experiencias que nunca habían realizado ( $\mathrm{p}$. 136, grifo nosso).

"La dispersión de los últimos años" é principalmente causada pelos efeitos da última ditadura militar argentina (1976-1983), período de horror e trauma histórico significativo para o país e para os personagens de Glosa. A sua publicação é pouco posterior a essa época. A repercussão do regime ditatorial e da militância política irrompem e desorganizam a vida dos protagonistas e dos outros personagens.

Sarlo (2016) sustenta que as forças que operam sobre os personagens pertencem à esfera da violência política porque, no caso de Glosa, é um princípio desorganizador que devasta um passado solar e compartilhado entre amigos, levando-os a um futuro de dispersão nefasto. Entretanto, como se disse mais acima, ainda nesse momento tão grave, a alegria de estar temporariamente junto dos amigos que sobreviveram persiste. Diante da dispersão dos amigos principalmente por circunstâncias históricas, os restos de um passado compartilhado de encontros felizes tornam possível que a rede de amigos sobreviva. Em concordância com Ricci (2009), o mundo-época miniaturizado no papel dobrado e evocado na expressão mencionada é o tempo da juventude dos membros da rede de amigos que compartilharam uma 
geografia, uma língua, um sentido do humor, uma série de hábitos e interesses, etc ${ }^{35}$.

Sendo assim, tal como aponta Jorge Bracamonte (2007) em "La importancia de Glosa en la obra de Juan José Saer", um dos sentidos do polissêmico título é também fazer um panegírico, um discurso de elogio e louvor a alguém. A partir desse significado conclui o seguinte:

\begin{abstract}
"hacer una glosa de, un panegírico de": está el homenaje a Washington Noriega, que en cierta medida es el pretexto que desencadena la principal conversación entre el matemático y Leto; pero además, y esto resulta lo principal de la lectura, está, articulándose, con el anterior homenaje, el realizado a Ángel Leto. [...] hablándose se escriben varios homenajes en el texto, sobre todo a los dos personajes mencionados, pero en ellos (a través de ellos) también se lauda, se celebra dos generaciones de la zona [...] con lo que ha sobrevivido [...] y con lo que ha muerto (p. 251, grifo nosso).
\end{abstract}

Retomando uma palavra do trecho do romance acima, "Dispersión" é também o título de um dos argumentos compilados em La Mayor, conjunto de relatos breves que Juan José Saer publica em 1976, primeiro ano da ditadura militar argentina. Estes pequenos textos são argumentos ou reflexões para narrativas em germe, que poderiam ou não se realizar em um porvir, inclusive Glosa, publicada em 1986. No primeiro parágrafo do texto, fala-se de uma geração separada pelo exílio:

La gente de mi generación se dispersa, en exilio. Del ramo vivo de nuestra juventud no quedan más que dos o tres pétalos empalidecidos. La muerte, la política, el matrimonio, los viajes, han ido separándonos con silencio, cárceles, posesiones, océanos. Años atrás, al comienzo, nos reuníamos en patios florecidos y charlábamos hasta el amanecer. Recorríamos la ciudad a paso lento, de las calles iluminadas del centro al río oscuro, al abrigo en el silencio de los barrios adormecidos, en las veredas frescas de los cafés, bajo los paraísos de la casa natal. Fumábamos tranquilos bajo la luna.

De esa vida pasada no nos quedan hoy más que noticias o recuerdos (SAER, 1998, p. 204, grifo nosso).

Apesar de existir outras causas, os efeitos do terrorismo de estado - "el exilio", "la muerte" e "la política" - predominam como razões para a separação dessa geração de amigos. Em vista disso, Bracamonte (2007) conclui que os personagens de Glosa simbolizam, no mínimo, quatro estados civis em 1981, momento de enunciação do narrador nas prolepses do romance:

\footnotetext{
${ }^{35}$ Sarlo (2016) ressalta que a narrativa saeriana construiu uma sociedade de personagens. Isso é fundamental nessa literatura porque não seria o que é sem esse sistema complexo, um grupo que se move pelos mesmos lugares - bares, pátios, "quinchos" e ruas - de uma cidade sem nome. Portanto, os seres que povoam os livros dão continuidade a um universo narrativo que o percebem como frágil e de maneira pessimista.
} 
1. Os exilados do país, a princípio por motivos a princípio por motivos pessoais e, logo a seguir, ideológico culturais, como foi o caso de Pichón Garay ${ }^{36}$, ou diretamente ideológicos, como foi o caso de Matemtico, que se exila depois de sofrer ameaças de morte dos militares;

2. Tomatis personifica os "insiliados", aqueles que ficaram, mas se encerraram em um isolamento cultural em contexto ditatorial;

3. Gato Garay, irmão gêmeo idêntico de Pichón, e Elisa, personagens centrais de outro romance do mesmo autor (Nadie nada nunca), tem o seu destino revelado em Glosa: os dois representam os desaparecidos;

4. Ángel Leto personifica o guerrilheiro que se suicidará quando é cercado pelas forças policiais da repressão militar.

Nas próximas páginas, nos centraremos nos destinos dos exilados Matemático e Pichón, do "insiliado" Tomatis e do guerrilheiro suicida Leto.

A condição de exilados de Matemático e Pichón Garay não os insere completamente no grupo dos demais exilados, como se pode ler no seguinte trecho:

Después del encuentro con los diputados, los otros miembros de la delegación habían propuesto almorzar todos juntos, pero sin haberse puesto previamente de acuerdo, Pichón y el Matemático rechazaron la invitación. Con los otros miembros de la delegación, no tenían, a decir verdad, más que principios en común, muy respetables en verdad, pero sin la fuerza de la experiencia o del recuerdo. Y despidiéndose de los otros, se habían puesto a caminar (2013, p. 135).

Por isso, discordamos de Kohan (2011) em relação a que a motivação da caminhada dos dois é claramente política, sem ambivalências. Pichón e Matemático recusam-se a almoçar com os outros exilados para passear juntos. A força da experiência e da lembrança compartilhada entre os caminhantes não é a mesma dos princípios políticos comuns ao grupo de exilados porque os laços de amizade que os unem não estão no terreno coletivo da categoria política que lhes é imposta, mas nas experiências e lembranças próprias, que também podem, mas não só, ser políticas. Tal como a celebração e o passeio, a alegria de estar junto com alguém que co-existiu em uma mesma rede de amigos na sua juventude predomina nesse novo passeio. No seguinte trecho, o narrador ressalta o bem estar que

\footnotetext{
${ }^{36}$ As circunstâncias do exílio - não-políticas - de Pichón Garay são relatadas em outra narrativa de La Mayor, "A medio borrar".
} 
Matemático sente ao lembrar desse passeio com Pichón especialmente por ter reavivado nele lembranças juvenis superpostas graças às lembranças do acompanhante:

La explosión súbita de las risas en el bulevar Saint Germain, el día anterior, resonaba en su fuero interno, con ese atributo singular de las rememoraciones sonoras que, aunque vuelven silenciosas a la memoria, no pierden ni timbre, ni color, ni intensidad. El bienestar le venía menos de la alegría implícita en la conversación, al fin y al cabo restringida, en sí misma y en el contexto en que había aparecido, que del efecto de ciertas palabras, de ciertas asociaciones las cuales, de un modo inesperado, le permitieron desplegar, o despegar más bien, porciones de su vida superpuestas entre sí y apelmazadas [...].Desde el día anterior, muchas de esas imágenes recubiertas habían reaparecido gracias, no a sus propios recuerdos, sino a los de Pichón -Pichón, ¿no?, que a pesar de los privilegios de la experiencia, no está menos perdido en la incertidumbre engañosa que él, que en aquellos días se había despreciado un poco por haber estado en Francfort, privándose de ese modo de atrapar, en un punto preciso de lo que es, la sucesión rugosa del acaecer con la red de sus cinco sentidos (2013, p. 139).

Ainda em um momento histórico que afeta negativamente a vida desse protagonista, o encontro relembra momentos felizes e, posteriormente, é lembrado em "rememoraciones sonoras" do riso.

Subitamente, logo após o trecho acima, o narrador nos conta que Matemático se lembra de um pesadelo. Ele caminha sozinho por uma cidade indeterminada e encontra uma fita em que vê infinitas expressões do seu próprio rosto. Ele ri dessas faces caricaturescas como em uma comédia, mas o fim deste sonho se torna um pesadelo que provoca um grito, como se vê no trecho transcrito abaixo:

[...] había empezado a comprender antes de despertar que cuando la cinta terminara de desplegarse, en el lugar en el que él estaba, en el que habría estado, el lugar que ocupaba su cuerpo, no quedaría nada, ningún meollo, ningún signo, ni siquiera algo que ese cuerpo puramente exterior hubiese estado trayendo dentro —nada, ¿no?, aparte de un vacío, una transparencia, el espacio invisible [...] (2013, p. 144).

Matemático antecipa e compreende o fim de seu sonho e o que poderia ser o fim de sua auto-imagem provavelmente como consequência da sua solidão pela separação física do seu lugar de origem e da sua rede de amigos. O temor da perda de identidade e do consequente nada é a última cena do primeiro salto que conta o destino político dos personagens.

Esse medo se realiza no outro protagonista de Glosa. A exclusão da pequena sociedade de amigos e, do meio familiar, a preocupação em decifrar as intenções de sua mãe 
quando menciona o pai morto se tornarão progressivamente indiferentes para ele. $\mathrm{O}$ futuro de Leto será o de militante, possivelmente da organização Montoneros ou do ERP (Ejército Revolucionario del Pueblo), segundo Sarlo (2016). A introdução de Leto na "clandestinidad" o leva a um processo de isolamento rigoroso e secreto, o qual suscita uma sensação de irrealidade, como se lê no seguinte fragmento:

Durante dieciséis o diecisiete años irá hundiéndose en un orden regido por normas tan estrictas, tan especiales, tan organizadas en circuito cerrado que, aunque elaboradas para constituir una asociación de personas cuyo fin es modificar la realidad, lo harán pasar a una irrealidad tan grande (2013, p. 224, grifo nosso).

A militância separa o protagonista dos grupos familiar e, especialmente, de amigos dos quais faz parte, o que torna a sua anterior identidade reduzida a um "rastro" que só aparece esporadicamente a partir dos encontros com amigos que estão fora desse grupo político, como se observa no fragmento que segue:

Poco a poco Leto irá dejando su trabajo, cada vez más implicado en la militancia política, en grupos cada vez más radicalizados, hasta que pasará a la clandestinidad, y del Leto habitual, salvo dos o tres reapariciones fugaces, no quedará ningún rastro, excepto para algunos amigos íntimos como Tomatis, Barco, el Gato Garay, a los que irá a visitar de tanto en tanto, siempre de un modo inesperado y fugaz, no para discutir de política, sino para estar un rato con personas a las que lo unen, no meramente principios, sino, para decirlo de nuevo, experiencias comunes y recuerdos, ya que se puede muy bien querer luchar contra la misma opresión, incluso con los mismos principios, pero por razones diferentes (2013, p. 224; grifo nosso).

No trecho acima e ao longo do segundo salto para o futuro, as organizações guerrilheiras são vistas como uma força política que exila o protagonista da sua anterior realidade e identidade, pois reproduz as formas autoritárias e opressivas do poder estatal contra o qual se propõe lutar. Como aponta Pablo Dema (2008) em "El relato literario y la memoria colectiva", há uma representação de uma igualdade de práticas entre ditadores e guerrilheiros:

Si por una parte el terrorismo de Estado es inadmisible y no tiene justificativa alguna, por la otra se denuncian las prácticas políticas de la izquierda como alienantes, mimetizadas con las prácticas del lado opositor y destructivas para sus miembros. Leto, de quien se cuentan todos sus antecedentes en las distintas novelas de Saer, ahora aparece en la adultez como un ser con una subjetividad absorbida por un sistema tan cerrado como el que se critica y enfrenta (grifo nosso). 
Florencia Abbate (2015) também ressalta que a ênfase na militarização da guerrilha acarreta em representar um conflito entre os fins e os meios. Por sua vez, Jorge Bracamonte (2007) aponta o caráter controverso ou polêmico na construção da visão a respeito da organização Montoneros $^{37}$, que o crítico, assim como Beatriz Sarlo (2010, 2016), identifica pelas práticas narradas, apesar de personagens e narrador nunca nomearem essa guerrilha no romance:

[...] la caracterización de lo que podía haber sido la dinámica de una organización guerrillera no va más allá de lo convencionalizado desde diversos puntos de vista al respecto. Dicha convencionalización se relaciona por un lado con ciertas caracterizaciones intelectuales que al respecto se hicieron a lo largo [...] del 80 durante la etapa dictatorial y posdictatorial, desde posiciones intelectuales muy diversas -; pero además no deja de vincularse llamativamente con caracterizaciones que se elaboraron en algunos casos desde el sentido común - el prejuicio que aún circula sobre que la mayoría de los militantes de base montoneros o del E. R. P. ("Ejército Revolucionario del Pueblo") eran "idiotas útiles" [...] o "locos" [...] pero que luego, con elaboración retórica sirvieron dichas caracterizaciones, de modo parcial, para formulaciones como la "Teoría de los dos demonios", que permitieron conceptualmente medidas regresivas para el desarrollo de los derechos humanos en la Argentina posdictatorial de los gobiernos de Raúl Alfonsín (1983-1989) y Carlos Menem (1989-1999) (p. 262-263).

Apesar desta pesquisa centra-se em analisar os efeitos da guerrilha na vida de Leto como membro de uma rede de amigos, o que Abbate (2015) e Bracamonte (2007) discutem é interessante para mostrar que a percepção de Leto em relação a sua prática militante não está, de acordo com o último crítico, narrativa e ideologicamente bem resolvido, o que torna esse ponto polêmico aberto à interpretação, à glosa crítica por parte do leitor.

A militância produz um corte na vida de Leto. Sua vida será a do militante. Viajará para Cuba, para o Meio Oriente, para a África, para o Vietnã, visitando, ainda segundo Sarlo (2016), a geografia da política revolucionária, espaço ideológico atravessado em primeiro lugar pelo caminho de Che Guevara. A crítica frisa que a militância arranca Leto de uma localização precisa e íntima, onde os encontros entre amigos ou conhecidos ocorrem, para pô-lo em um espaço ideológico, onde os países são faróis da revolução, lugares que se visitam

\footnotetext{
${ }^{37}$ Segundo o crítico, tal organização "pasa a la clandestinidad en su enfrentamiento primero con la derecha instalada en el gobierno constitucional (a partir del ascenso, en el seno del gobierno peronista, de López Rega, a partir de 1974, cuando la guerrilla peronista Montoneros entra en la clandestinidad debido a su abierta confrontación con el General Perón), y luego con la dictadura militar (recordemos que junto al Ejército Revolucionario del Pueblo, Montoneros fue la principal organización guerrillera que se confrontó en una abrumadora inferioridad numérica en términos militares, con las Fuerzas Armadas que a partir de 1976 ocuparon las estructuras del Estado argentino, lo que supuestamente justificó en términos de la reacción civil-militar conductora de la dictadura el denominado 'combate a la subversión"” (BRACAMONTE, 2007, p. 260).
} 
cumprindo a viagem internacionalista de doutrina. Também aponta que em um romance onde o espaço se percorre a pé, registrando a familiaridade minuciosa do muito conhecido, a prolepse introduz uma dimensão abstrata, onde o conhecimento é prévio ao espaço, pois se vai a Cuba e Vietnã porque são países revolucionários onde as experiências que se transmitem devem ser consideradas universais. Nisso se diferenciam também das experiências e lembranças da festa de Washington, tão dificilmente universais que dois presentes, Botón e Tomatis, fazem delas relatos diferentes. O corte entre um espaço e outro é também o corte na vida de Leto.

No trecho de Glosa acima, se observa novamente a busca de laços afetivos que vão além dos princípios políticos. Meses antes do suicídio de Leto, o narrador nos conta, usando o futuro do indicativo, que ele visitará Tomatis, amigo que estará no auge de uma depressão que tinha começado na caminhada que fizeram muitos anos atrás. Uma de suas poucas atividades é estar durante horas em frente à televisão. $\mathrm{O}$ narrador nos relata brevemente o conteúdo do que este personagem assiste:

Cada madrugada, cuando las sombras electrónicas, los simulacros de colores chillones, los petimetres y las muñecas Barbie miniaturizados de las series industriales americanas, interrumpidos cada cinco minutos por los cartones publicitarios concebidos por y para retardados, las propagandas del ejército invitando a los jóvenes sin trabajo a integrar sus bandas de homicidas y de torturadores para salvar la patria del cáncer de la subversión (2013, p. 228, grifo nosso).

Acima, nota-se o uso da propaganda televisiva pela ditadura militar que procura cúmplices do regime, estupidificados pelo Estado. Sobre isso, Abbate (2014) frisa o seguinte quando analisa o mesmo trecho:

\footnotetext{
A través del discurso indirecto libre el narrador refiere los pensamientos de Tomatis sobre el poder estatal, encarnado en "bandas de homicidas" y torturadores. En la representación del derrumbe depresivo y el odio de Tomatis convergen Estados Unidos y su industria cultural con las Fuerzas Armadas y el discurso oficial del Estado argentino (p. 92-93).
}

Concordamos que essa postura crítica não está tão desenvolvida em Glosa, porém é uma atitude potencial que se elabora com mais clareza em Lo imborrable (1993), romance no qual Tomatis é o seu protagonista. Grosso modo, descobrimos nesse outro romance que a sua depressão chega ao ápice também por razões políticas: a terceira esposa da qual se divorcia 
denuncia uma militante política que Tomatis esconde na sua casa.

Diante da estupidificação de Tomatis frente à televisão, Leto se arrepende de ter ido visitá-lo, mas, subitamente, o amigo parece "acordar" e o apresenta à sua irmã escondendo a sua condição de guerrilheiro e o leva a um outro lugar longe da televisão para poderem conversar melhor.

Já no terraço, Tomatis lhe oferecerá vinho - bebida que os amigos tomaram na celebração, de acordo com as versões desse evento -, mas Leto, por ser um guerrilheiro que deve estar sempre alerta, não aceitará e pedirá doces, único prazer alimentício que parece ter lhe sobrado. De qualquer maneira, comida e bebida voltam a ser parte desse encontro entre velhos amigos. Entretanto, ao contrário do que acontece com o passeio feliz de Pichón e Matemático em um espaço de exílio, a sua decepção com a transformação de Tomatis é evidente porque esperava reencontrar-se com o amigo com o humor ferino de sua juventude e não um "cuarentón" deprimido. Além disso, nota o desinteresse de Tomatis na conversa, apesar dele lhe fazer perguntas comprometedoras provavelmente por ser um militante político. Entretanto, mais adiante, essa decepção se transforma em compaixão quando percebe que o humor que Tomatis expressa às vezes se resume a reproduzir mecanicamente slogans publicitários.

Depois de um tempo de uma conversa interrompida sempre pelo interesse de Tomatis na programação televisiva, o amigo pergunta a Leto subitamente sobre a pastilha de cianureto que carrega consigo, prática comum dos militantes guerrilheiros para que se suicidem se forem pegos por forças policiais do regime militar:

¿Es cierto lo de la pastilla? ¿La llevas encima?, le preguntará Tomatis, inclinándose hacia él, con la misma sonrisa cómplice y discreta con que podría haberle hablado de una foto pornográfica. Leto no dirá ni que sí ni que no; mirando a Tomatis fijo en los ojos, buscará la sonrisa de complicidad de unos segundos antes, pero para su sorpresa, los ojos de Tomatis, desiertos del menor destello de humor, le lanzarán por primera vez desde que habrá llegado a la casa una mirada viva, casi imperativa; los ojos, que habrán estado empañados y huidizos durante todo el encuentro, brillarán ahora tan fuerte que Leto creerá, de un modo erróneo, que reflejan las luces de la terraza. Por fin, Leto desabotonará despacio el bolsillito de seguridad que se encuentra bajo el cinturón y sacará la pastilla y, abriendo de golpe la mano, la hará aparecer en el hueco de la palma, acercándola a Tomatis, y durante ese movimiento más bien rápido que lento, la cápsula de plástico en la que vendrá encerrada reflejará, al pasar, alguna de las luces. Tomatis se inclinará para observar, con sacudimiento de cabeza lentos, de corroboración, primero afirmativos, negativos después, y por último otra vez afirmativos. Exacto, exacto, dirá, como pensando en otra cosa. Y él, Leto, ¿no?, volverá a guardarse la pastilla (2013, p. 231, grifo do autor ). 
Enfim, Leto nota alguma reação mais vívida e menos fria de Tomatis, provavelmente uma vivacidade que lhe era característica, não porque os dois conseguem compartilhar lembranças de um passado juvenil comum, apesar desta ter sido a razão de sua visita. Entretanto, é provavelmente por causa da relação juvenil que teve e tem com Tomatis que Leto confia e lhe mostra a pastilha de veneno.

Mais adiante, o momento em que Leto se suicida encerra o segundo salto temporal. Depois de notar a emboscada que se forma ao redor da casa que pode ser o seu lugar de nascimento, o personagem pensa o seguinte:

\footnotetext{
"Ustedes dos, como los que están atrás de los autos y de los árboles, como los que esperan en las esquinas, como los que ya deben estar en la puerta de entrada, en el techo a lo mejor, en el fondo del patio, carecen de realidad, son como fantasmas o como nubes de humo, porque yo tengo la pastilla, la acabo de tocar con la yema de los dedos, la pastilla que anula de un solo clac el big bang, la expansión insensata y ciega de sus chafalonías y su seudoeternidad irrisoria" Y, volviendo un poco a tientas hasta la mesa de luz, y recogiendo de la muesca del cenicero el cigarrillo para darle dos o tres pitadas antes de aplastarlo, se llevará la pastilla a la boca con un gesto tan rápido que antes de morderla, sosteniéndola un instante con los dientes sin hacer presión, deberá expeler el humo de la última pitada (2013, p. 234, grifo nosso).
}

O protagonista opõe a carência de realidade dos seus inimigos, sombras desconhecidas e incertas, à realidade de seu suicídio. Essa se associa ao consumo de cigarros, um dos poucos prazeres que o guerrilheiro se permitia por sua obrigação de estar sempre alerta e atento a qualquer perigo, assim como os doces que ele come juntamente com Tomatis em sua última visita. O fumo esteve presente na caminhada e na festa evocada, o que, por conseguinte, pode ser um vestígio de um tempo passado e desperdiçado entre amigos.

Por sua vez, em “Amigos”, outro argumento de La mayor, Leto, já um guerrilheiro, passa alguns dias no apartamento de Tomatis esperando o momento para matar um "dirigente sindical que había traicionado a sua clase” (SAER, 1998, p. 166). E essa proximidade com a morte leva Leto a lembrar e a refletir sobre a morte de um amigo aos dezoito anos. Tal evocação ocorre enquanto o personagem folheia os escritos de Tomatis reunidos em uma pasta entitulada "PARANATELLON, PARANATELLES o PARNASO", que é, segundo indica o subtítulo, uma "antología comentada del litoral” (1998, p. 166). Política, literatura e amizade se entrecruzam nessas horas de espera. E Leto conclui : "No se mata más que a los amigos, pero ni aún a ellos se mata, porque no se mata lo que es inmortal" (1998, p.167, grifo do autor). Em "La condición inmortal: Políticas y poéticas de la amistad en la narrativa 
de Saer", Paulo Ricci (2011) conclui que "Amigos" e a narrativa saeriana como um todo contam o apagamento dos acontecimentos e a consequente presença indeterminada da vida humana. Entretanto, salienta que a amizade e a literatura sobrevivem porque ambas estão entrelaçadas e feitas de uma matéria única e imortal.

Sendo assim, para Sarlo (2016), o que aconteceu com Leto não pode ser julgado segundo a representação de lembranças trágicas de militância guerrilheira, cuja ambição realista-documental rapidamente poderia perder seu teor de verdade porque demanda a prova com fatos. O que aconteceu com Leto é o final mais trágico da comédia, o episódio em que se mostra mais explicitamente a devastação que arrasou a pequena sociedade de amigos por razões especialmente político-históricas.

Diante das ruínas de um passado feliz, os amigos se reencontram principalmente em memória de um passado compartilhado que sobrevive em restos de memória como um souvenir (poema) ou uma linguagem (mini-expressão "los mosquitos de Washington). Nesse futuro nefasto - algo que infalivelmente virá, um passado que ainda não foi presente - de exílio, guerrilha e morte, essas reuniões iluminam a vida desse grupo em dispersão, explicitando a persistência do laço afetivo que existe entre eles, mas também se evidencia a ampliação das exclusões, não mais temporárias, mas sim definitivas, mortais. Encontros ainda felizes, mas marcados por ausências irrevogáveis que suscitam melancolias mais graves.

\subsection{Inadequação}

Beatriz Sarlo (2016) enfatiza que o tratamento direto da política em Glosa (1986) é original, pois não segue as duas tendências da literatura argentina dos anos 80 que representam o período ditatorial: a abordagem alegórica e a documental-realista. De fato, o tratamento da política se concentra na narração do destino dos personagens em uma temporalidade precisa e, inicialmente, condensada.

A introdução de uma referência direta aos efeitos da ditadura militar aparece inicialmente de maneira breve entranhada em um texto denso que se concentrou especialmente em narrar lentamente encontros prazerosos por meio de uma escrita que tem como uma de suas principais marcas de estilo uma "delectación morosa respecto a la materialidad de las palabras" (DALMARONI e MERBHILHAÁ, 1999, p. 327). No seguinte trecho, o narrador revela que Matemático está na condição de exilado político: 
Está en el bulevar Saint-Germain con Pichón Garay; vienen caminando desde l'Assemblée Nationale en dirección a la Place Maubert [...]; en la entrada de l'Assemblée se han separado del resto de la delegación - un grupo de exilados que acaba de ser recibido por el bloque de diputados socialistas y que les ha prometido, el bloque, ¿no?, ocuparse del asunto, las masacres, las desapariciones, las torturas, los asesinatos en plena calle y en pleno día, etc., etc., en fin, como decíamos, ya desde el principio nomás, o decía mejor, un servidor, y más o menos, ¿no?, todo eso (p. 130, grifo nosso).

O fragmento acima mostra que, a não ser o exílio do personagem principal, as consequências do terrorismo de estado argentino não estão associadas a nenhuma pessoa específica. Entretanto, logo no seguinte parágrafo a esse trecho, tais procedimentos são associados ao destino de alguns personagens do universo saeriano, silenciados em outras obras do autor ${ }^{38}$ :

El año anterior, en mayo, Washington ha muerto de un cáncer de próstata; en junio, el Gato y Elisa, que estaban viviendo juntos en la casa de Rincón desde que Elisa y Héctor se separaron, han sido secuestrados por el ejército y desde entonces no se tuvo más noticias de ellos. Y para los mismos días, aunque se haya sabido un poco más tarde, Leto, Ángel Leto, ¿no?, que desde hacía años vivía en la clandestinidad, se ha visto obligado, a causa de una emboscada tendida por la policía, a morder por fin la pastillita de veneno que, por razones de seguridad, los jefes de su movimiento distribuyen a la tropa para que, si los sorprende, como dicen, el enemigo, no comprometan, durante las sesiones de tortura, el conjunto de la organización. Y Leto ha mordido la pastilla. El Matemático, por otra parte, está bastante al tanto de todas esas cosas, puesto que, sin estar muy de acuerdo con sus ideas, ha compartido con su mujer, durante varios años, hasta que la mataron, en mil novecientos setenta y cuatro, esa existencia singular (p. 130-131, grifo nosso).

O uso do tempo verbal do pretérito perfeito do modo indicativo, acima em itálico, para contar os efeitos do terrorismo de estado na vida (e morte) dos personagens nos trechos citados e ao longo desse primeiro salto do presente da caminhada para o futuro dos personagens indica, entre outras coisas, que o fato passado ainda tem implicância no presente de quem o utiliza. Sendo assim, as consequências horríveis do período ditatorial possuem relevância para os personagens. Pode-se pensar na hipótese de que essa importância esteja na revelação em si desses destinos, uma vez que ocorre a ruptura do silenciamento desses futuros políticos na narrativa saeriana como um todo.

Além do mais, considerando o contexto de escrita do texto - período imediatamente pós-ditatorial (1986) -, as consequências do horror vivido por uma parcela da sociedade são

${ }^{38}$ Em "La condición mortal", Beatriz Sarlo (2010) tem como centro o argumento de que Glosa encerra violentamente o destino de muitos da sociedade de personagens que circula na obra saeriana como um todo. 
revelados e, por isso, ainda fazem parte e possuem relevância na recepção contemporânea do romance, apesar da existência de poucos estudos de Glosa nessa época ${ }^{39}$. Segundo Sarlo (2016), a história entra na narrativa saeriana principalmente por seu caráter político, isto é, de agente ativo no presente dos leitores mais imediatos do romance.

Florencia Garramuño (2010) em "Las ruinas y el fragmento. Experiencia y narración, en El Entenado y Glosa" chama essa escritura austera e sem adjetivos de "notación telegráfica”. Essa se justifica como uma resistência à narração desses destinos, o que evita o tom melodramático do horror histórico-político e sua repetição compensatória e consoladora em um texto literário.

De fato, a escrita breve e condensada evita o melodrama e não sublima ou torna banal o horror histórico-político. Entretanto, é somente na introdução dos efeitos do período ditatorial que essa escrita breve se dá. Em seguida, alguns fios narrativos inicialmente condensados nos fragmentos anteriores se desenvolvem nessa escrita morosa que lhe é marcante. Por exemplo, o leitor saberá o porquê da condição de exilado de Matemático e da militância e suicídio de Leto.

Sendo assim, essa compacta revelação dos futuros silenciados em outras narrativas do escritor não visa somente evitar determinados efeitos e mostrar resistência à narrativa de um trauma histórico, algo que se vê na prosa saeriana e na literatura contemporânea desde os períodos pós-guerra mundiais ${ }^{40}$. Há também o propósito de evidenciar o período ditatorial como um inicial irromper marcadamente concentrado que interrompe e se entranha numa escrita dilatada de encontros prazerosos entre amigos como foi o passeio de Leto e Matemático fazendo elucubrações múltiplas sobre um aniversário em que nenhum dos dois foi.

Em La dicha de Saturno. Escritura y melancolía en la obra de Juan José Saer, Premat (2002) demonstra que a melancolia como comportamento e sensação predomina na narração, nos personagens e nas visões de mundo da narrativa saeriana ${ }^{41}$. Entretanto, aponta

\footnotetext{
${ }^{39}$ Em “Vislumbres críticos: un horizonte de ‘deseo’ y ‘alucinación’”, María Bermúdez Martínez (2010) percorre a recepção crítica dos romances El entenado e Glosa, e aponta, até aquele momento, a escassez de estudos sobre o último.

40 Pensadores como Walter Benjamin em "O narrador" e Theodor Adorno em "A posição do narrador no romance contemporâneo", refletem a partir da figura do narrador a problemática da narração nos períodos posteriores às guerras mundiais: a dificuldade ou incapacidade de poder narrar depois da Europa ter vivido experiências traumáticas de guerra.

${ }^{41}$ De acordo com o crítico, a melancolia possui as seguintes características na literatura de Saer: estado de ânimo ensimesmado, triste e queixoso; presença inibidora da memória e do passado; falta de energia vital; misantropia e aparente falta de sentido na linguagem e no mundo.
} 
que em Glosa o estado melancólico, inclusive o suscitado por razões políticas, está em segundo plano porque os momentos de prazer estão em primeiro.

O romance é possível no limite restrito da caminhada, entre a primeira e a última página/quadra, apesar das incertezas, da proliferação de um passado inapreensível e de um futuro nefasto para os personagens. $\mathrm{O}$ instante de prazer - que é também o tempo de leitura é efêmero, mas efetivo. Por isso Sandra Contreras (1991) defende que a demora na narração desses encontros de curto tempo cronológico é uma forma de resistir à consciência da dor da finitude humana, porque o prazer que as reuniões proporcionam para os personagens-amigos se reflete na narração e leitura, e faz com que personagens, narrador e leitores se esqueçam provisoriamente de que esses encontros, assim como sua narrativa e leitura, terão um fim.

Partindo da análise do poema que é epígrafe do romance - "En uno que se moría/mi propia muerte no vi/pero en fiebre y geometría /se me fue pasando el día/ y ahora me velan a mí" -, a crítica observa que os versos recusam o tom grave que pressuporia a profundidade da sua mensagem (a experiência de não ser contemporâneo da própria morte), pois a sua sonoridade é leve, lúdica. Uma música inadequada, cômica possivelmente desvia a atenção do leitor do conteúdo grave da mensagem, distração que antecipa o que acontecerá no romance que lhe segue. Tal como vimos na primeira parte desta pesquisa, Leto e Matemático se distraem provisoriamente dos seus traumas no passeio que prolonga a festa porque emergem do pântano de suas consciências para conversar sobre a celebração. Isto é, a melancolia que carregam dentro de si não cessa, mas é aliviada momentaneamente. Além do mais, apesar da crítica não dizê-lo de maneira explícita, muitas vezes o humor resulta de uma tensão provocada pelo desconcerto entre um tom, um comportamento e um tema. O poema e o romance são escritos de maneira semelhante a como escreve Brás Cubas, "com a pena da galhofa e a tinta da melancolia".

Contreras (1991) frisa que tal inadequação se evidencia mais ainda na já mencionada cena de leitura desses mesmos versos na caminhada: Tomatis, autor do texto na narração, muda o tom de sua voz e lê o poema com uma irônica solenidade; Matemático compreende e se extasia; Leto não escuta; Tomatis volta a lê-lo menos atento ao poema que à reação estética de Leto; Matemático controla e reprova com seu olhar a desatenção desse amigo; Leto, pressionado pela dupla vigilância, outra vez não escuta. A crítica presume que os leitores esquecem o sentido profundo dos versos e riem porque se distraem pela engraçada tensão da cena. Esclarece que a demora nesses momentos não provoca no leitor o riso que tem a força 
de uma gargalhada desdenhosa ou cínica. Pelo contrário, o riso em Glosa não é um ataque contra a morte, mas possui a astúcia do esquecimento. Resistir à tristeza, "hacerse el tonto".

Essas e outras análises levam a crítica acima - e nós com ela - à conclusão de que, assim como os personagens-amigos, narrador e leitores querem esquecer a dor do fim, desfazem-se provisoriamente dos relatos do futuro que irromperão no romance transformando negativamente, ou às vezes destruindo, como é o caso de Leto, a vida de muitos dos membros do grupo de amigos.

O prolongamento da festa em evocações na caminhada que se dilata prazerosamente adia provisória e conscientemente o relato da separação e o fim do grupo de amigos por razões especialmente político-históricas. Contra os vislumbres de tristezas futuras para os personagens, prevalece no tempo de leitura do romance a demora nos instantes efêmeros - os "atisbos de fiesta" - e, ao mesmo tempo, duradouros desses encontros. A alegria de estar juntos fornece-lhes uma espécie de anestesia para a finitude humana porque o riso tem o poder de exorcizar o medo da morte, mas só durante o tempo que dura uma gargalhada.

A morte é uma catástrofe anunciada e inevitável, mas os personagens e o leitor desconhecem o dia e o modo como acontece até que o romance esteja avançado. O leitor sabe que os personagens se dirigem para um fim, mas quando o fim não é conhecido, ou quando se finge não conhecê-lo, podemos esperar que não esteja próximo, até o momento em que irrompe e o apanha de surpresa.

Talvez seja por isso que, além do prolongamento do presente prazeroso, o segundo salto, o que detalha os futuros mais trágicos dos personagens - a depressão de Tomatis e a guerrilha e suicídio de Leto -, esteja predominantemente no futuro do indicativo, tempo que coloca o que acontecerá com os dois personagens "fora" do presente da narrativa, tal como aponta Pereira (2006) em sua tese sobre o romance.

Ademais, os dois saltos para o futuro da caminhada para contar o destino trágico dos personagens não são o fim do romance. Depois que a voz narradora deixa o leitor consciente de que a dispersão da rede de amigos virá e de que Leto se suicidará, última cena do segundo salto, há uma volta para o presente de um Leto jovem, vivo e ignorante do que lhe espera.

O romance-comédia termina bem, mas provisoriamente. De acordo com Saer, no mesmo diálogo com Piglia mencionado anteriormente ${ }^{42}$ :

\footnotetext{
42 SAER, Juan José; PIGLIA, Ricardo. Diálogo. Santa Fe: Centro de Publicaciones Universidad Nacional del Litoral, 1995.
} 
Yo llame a Glosa una comedia porque la comedia está antes del fin. El fin está elidido en las comedias. Terminan bien, pero provisoriamente.

Se puede tener esa visión del mundo: que está provisoriamente bien. Y cuando me refiero al mundo no solamente me refiero a la sociedad, a la vida de cada individuo, sino también al universo. En Lo imborrable, el narrador dice, en un determinado momento, "la tierra está girando, pero provisoriamente". Cuando tomamos conciencia de que todo es provisorio nos damos cuenta de que, al mismo tiempo, es una situación altamente cómica. Si escuchamos el discurso del presidente de la República a propósito de su reelección y sabemos que vivimos en un universo provisorio, esas pretensiones naufragan inmediatamente en el ridículo. Pienso que el humor cumple esa función (1995, p. 83, grifo nosso).

Portanto, podemos pensar que, além do esquecimento provisório da consciência de que tudo tem um fim nos encontros desses personagens que se reflete na narração e no tempo de leitura, a consciência de que tudo é provisório dá um novo sentido para o romance depois que o leitor tem acesso a esses futuros: os personagens-amigos, juntamente com narrador e leitores, devem aproveitar o presente enquanto ele não se esvai. Carpe diem. O dom do instante vivido e compartilhado entre amigos é uma dissonância, uma inadequação feliz a esse tempo devastador do político-histórico.

Piglia (2001) menciona no prólogo de Tres propuestas para el próximo milenio (y cinco dificultades) que, desde os períodos repressivos que se dão ao longo da história argentina, a amizade e a conversa entre amigos se transformaram em um fato político. Esse intercâmbio privado ocorre em um tempo desperdiçado e em um espaço contra-público, tornando-se uma forma de construir e sustentar redes sociais extra-estatais e micro-políticas contrárias à lógica despótica da produtividade econômica e do controle policial. Em vista disso, a amizade é uma forma privada de resistência e atua como alternativa em meio da massiva unanimidade dos discursos públicos e da deliberada desagregação dos laços de solidariedade, promovidas desde o poder. Só os amigos sabem que se entender é difícil e só eles falam uma linguagem múltipla em meio da imposição generalizada do sentido único e do uso oficial de uma linguagem tecnocrática arrogante e vazia. Portanto, conclui Piglia, a conversa entre amigos é uma condensação cifrada e microscópica da convivência possível no meio da destruição programática da Argentina atual.

De maneira semelhante, Lucero e Balderson (2010) vêem que, contra um ideal de nação ou de filiação partidária, em Glosa há uma representação de uma sociedade alternativa de amigos que têm em comum um humor, uma atitude disposta à contenda e, por conseguinte, 
à autocrítica.

Sendo assim, o que implica evitar, esquecer ou fingir esquecer o fim de uma rede de amigos? A diversão, o desvio para outras maneiras de viver que não são estritamente políticas, a vida entre amigos. A jovialidade dessa suaviza a dor do fim, mas também a aprofunda porque lembra a razão de sua existência. 


\section{CONSIDERAÇÕES FINAIS}

Os personagens-amigos são vidas construídas de maneira semelhante ao que Agamben (2017) expõe no seguinte trecho de $O$ uso dos corpos:

[...] cada um dos modos, dos atos e dos processos do viver [ ...] são possibilidades de vida, sempre e sobretudo potência. [...] A forma do viver nunca é prescrita por uma vocação biológica específica nem é marcada por qualquer necessidade, mas, por mais costumeira, repetida e socialmente obrigatória que seja, conserva sempre o caráter de uma possibilidade real, pondo em jogo o próprio viver (p. 233-234, grifo nosso).

Por isso, os amigos de Glosa constituem uma comunidade de seres potenciais, principalmente porque não são sempre de uma determinada forma ou outra, não possuem identidades fixas que esgotem as potências dos personagens, o que favorece a representação de uma relação entre personagens que são diferentes física e/ou psicologicamente entre si. Os protagonistas, por exemplo, são antinômicos em muitos aspectos - físico, vestimenta, origem social, visão de mundo e personalidade -, mas co-existem em um mais amplo círculo de amigos.

Nesse sentido, sustenta Agamben (2017), “só podemos comunicar-nos com outros por meio daquilo que em nós, assim como nos outros, continuou em potência, e toda comunicação [...] é comunicação não de algo comum, mas de uma comunicabilidade” (p. 237). Sendo assim, a amizade caracterizada por Agamben (2009) em "O amigo" e praticada de maneira semelhante no romance não é algo propiciado pela intersubjetividade. A possibilidade de comunicar-se sem com isso comunicar algo comum, algo que se mostrou impossível no romance, sustenta a prática de amizade entre os personagens. Essa é conformada por uma co-existência. Portanto, a festa e as caminhadas acontecem, existem por causa da amizade entre a rede de amigos e não o contrário. Muito provavelmente Leto e Matemático não se aproximariam e conversariam se não fosse para atualizar ou reforçar a sua co-existência na mesma rede de amigos porque essa está abalada pelas suas ausências. É dessa atualização que surge uma disponibilidade para o con-sentimento mais intenso entre os dois, ainda que temporário. Eles não se aproximam para (re)construir uma experiência estético-narrativa essencial para o grupo, mas a própria (re)construção é essa aproximação, essa co-existência entre membros de uma rede de amigos. 
Tal ideia de amigo permite uma relação dissimétrica e opaca entre personagens construídos como singularidades heterogêneas, mutantes e inacabadas, assim como a construção do relato da festa que uniu momentaneamente os protagonistas. Por mais que as lembranças sejam heterogêneas, mutantes e insuficientes para recuperar um tempo que sempre foi perdido, a persistência das memórias de experiências juvenis possibilitam que essas relações se prolonguem em um tempo de ausências mais graves do que a falta em uma festa. A centralidade na narração dilatada da gratuidade, da inoperância desses encontros celebratórios entre amigos que doam, que desperdiçam tempo entre si adia o relato da sua dispersão, mas esta diminui porque se joga para um segundo plano narrativo a força política que pressiona alguns personagens no presente, mas especialmente nos saltos ao futuro da caminhada, mesmo que provisoriamente.

Por mais que os personagens-amigos riam na face da finitude humana, eles vão se separar e/ou morrer. $\mathrm{O}$ riso é impotente em relação à dor ou à morte, mas talvez tenha algum poder sobre a vida. Na festa de La grande, os personagens riem em situações pretensamente assustadoras. Os amigos, já alimentados e alcoolizados, começam a contar histórias com o seguinte teor à mesa:

[Violeta, um caso amoroso de Tomatis] comenta que en los años de la dictadura, durante el terror, cuando el miedo, el asco, lo arbitrario, la crueldad y el dolor ocupaban todo, en medio del escarnio y de la masacre, ocurrían cosas a la vez angustiosas y cómicas, tan absurdas a veces que terminaban causando risa (2017, grifo nosso).

Uma dessas histórias de medo e riso é a que conta Marcos Rosemberg, advogado presente nessa festa e também no aniversário (re)construído em Glosa. Quando procura um coronel para se informar de "la suerte de un desaparecido", o seguinte acontece:

[o coronel] levantó la cabeza y le dirigió una mirada estudiada, entre inquisitiva y severa, de modo que él, Marcos, empezó a informarle que en tanto que abogado venía a averiguar el paradero de una persona desaparecida tres días antes; pero el coronel, dando un puñetazo en el escritorio, le dijo que en el país no había desaparecidos, que solamente había subversivos que se escapaban al extranjero para huir de la justicia y que pretender lo contrario constituía un insulto a las fuerzas armadas y al gobierno. El problema era que, con la violencia del puñetazo que había dado contra el escritorio, su peluquín se había desplazado un poco en la cabeza y a su pretendida afirmación de autoridad la contradecía la incongruencia del peluquín mal pegado contra su calva. Ebrio de su propio discurso, el coronel seguía pontificando y amenazando, pero Marcos ya no lo escuchaba, haciendo unos esfuerzos terribles para no echarse a reir, al mismo tiempo que temía que, si el coronel seguía exaltándose, el peluquín se le cayera de la cabeza, porque a 
medida que la situación se iba prolongando, a Marcos se le hacía cada vez más evidente que si el coronel se daba cuenta de lo que ocurría, él era un hombre muerto, nunca volvería a salir a la calle. Así que en medio del discurso del coronel se paró decidido a irse, balbuceando que no llegarían a entenderse, pero con dos trancos enérgicos, el coronel rodeó el escritorio y vino a pararse a treinta centímetros de su cara, echándole la mirada más amenazadora que encontró en su repertorio. Pero con los movimientos bruscos que había hecho, el peluquín se había desplazado todavía más y casi colgaba sobre la oreja izquierda. Dividido entre el miedo y la risa, Marcos decidió exagerar el miedo pensando que si, sin poder contenerse, se echaba a reír, el coronel iba a pensar que se trataba de una risa nerviosa. Con el más popular de los desprecios, el coronel lo tuteó de golpe: ¡Andá cantale a Garay!, le lanzó. ¡Salí por esa puerta antes de que me arrepienta y te lo haga pagar caro! Marcos se dirigió a la puerta y las primeras risas ahogadas lo sacudían, igual que las primeras arcadas antes de un vómito, y el coronel, viéndolo de espaldas, debía pensar que era el terror lo que lo hacía estremecerse tanto, de modo que redoblando su desprecio, masculló en el momento en que Marcos atravesaba la puerta (2017, grifo nosso).

O riso, talvez mais forte porque contido, torna inoperante o medo que o poderoso quer causar no personagem. O riso subverte o medo, corrói-o, mina-o, torna-o mais pequeno. Sem medo, não há reverência. Disso decorre que uma das principais características do humor, do risível é a sua irreverência. O que devasta o medo, devasta o respeito. E é isso que Glosa quer causar no leitor.

Em uma entrevista ${ }^{43}$ com o interessante título "Un paso de comedia negra", o escritor fala sobre Lo imborrable como o lado escuro de Glosa. Logo, presumimos que o autor, e nós com ele, considera o último um romance luminoso, o que não o torna menos contemporâneo à sua época, apesar de, em “¿Qué es lo contemporáneo?”, Agamben (2011) enfatizar que o contemporâneo " mantiene la mirada fija en su tiempo, para percibir, no sus luces, sino su oscuridad" (p. 21).

Essa ideia de contemporâneo encontra-se em outras narrativas como Lo imborrable, como se viu mais acima. Em "Lo imborrable de Saer y lo imborrable de la amistad", Hernán Maltz (2013) chama a atenção para a ausência do "elenco estable saeriano", a rede de amigos que percorre grande parte das narrativas com exceção do protagonista, Tomatis. Por outro lado, o protagonista não deixa de enfrentar o que o crítico chama de "enemigos" ou "enemistades", como Walter Bueno, escritor oficial da ditadura, ou sua ex-sogra, inimiga principal, evidenciando uma mistura descontínua entre público e privado nas relações interpessoais entre o protagonista e os outros personagens. Entretanto, o humor não está ausente do romance: há novamente uma inadequação, porque o narrador-protagonista Tomatis

\footnotetext{
${ }^{43}$ SAER, Juan José; POMARANIEC, Hinde. "Un paso de comedia negra”. In: PRIETO, Martín (comp.) Juan José Saer: una forma más real que la del mundo. Buenos Aires:Mansalva, 2016.
} 
conta os fatos mais horrorosos no tom jocoso e ácido do humor negro. Sendo assim, podemos presumir que a ausência da rede de amigos torna muito mais grave o "insiliamento" de Tomatis em Lo imborrable. Esse tem uma visão contemporânea, pois percebe a escuridão do meio social em que vive, uma vez que a sociedade está repleta de homens cínicos e perversos.

Exemplifiquemos com outro texto escrito mais ou menos da mesma época de Glosa: "Cadáveres", do militante, antropólogo e poeta argentino Néstor Perlongher, poema longo publicado em livro em $1987^{44}$, um ano depois da publicação do romance de Juan José Saer, 1986. Em tal texto, os efeitos da última ditadura militar argentina são representados na violência e no silenciamento sobre de corpos de desaparecidos que se acumulam em cada estrofe.

Em “Poesía y política en Néstor Perlongher", Javier Gasparri supõe o seguinte sobre os dois primeiros livros de poesia de Perlongher: Austria-Hungría (1980) e Alambres (1987), livro em que se publica "Cadáveres":

Austria-Hungría (1980) y Alambres (1987) marcarían la presencia fuerte de una escritura política, con un claro impulso de intervención (incluso de provocación), al mismo tiempo que una aspiración a nombrar, registrar, la violencia política que le era contemporánea, o a lo sumo un pasado reciente, pero en cualquier caso inmediata (2012, p. 18).

Essa violência política contemporânea ao poeta é, para Florencia Garramuño (2012), no mesmo livro em que analisa a narrativa saeriana, exemplo do "exterior [...] como lugar de onde emanam forças em movimento constante que afetam a linguagem e que, nessa afetação, a constituem" (p. 203). Entretanto, a crítica frisa que é difícil falar do político-histórico na poética perlongheriana porque sua poesia obtura a referência direta e literal pelo constante uso de recursos sonoros e fonéticos como aliterações, consonâncias, assonâncias e repetições. Tal resistência à referenciação combina-se com o que Garramuño nomeia "estilhaços da história", que são:

Restos de uma história fragmentada [que] aparecem no continuum de um poema, interrompendo sua gramática e o devir de um significado linear, dando lugar a uma construção do texto pautada a partir do trabalho sobre esses restos (2012, p. 208).

\footnotetext{
${ }^{44}$ De acordo com Garramuño (2012), Perlongher escreveu "Cadáveres" durante uma longa viagem que fez de Buenos Aires a São Paulo em 1981, ano em que começou o seu exílio. Em 1984, um ano depois do fim da ditadura na argentina, o poema é publicado na Revista de (poesia).
} 
No caso de “Cadáveres”, tais restos são literalmente mortais. Política e poética são indissociáveis. Por conseguinte, a crítica vê os poemas e ensaios de Néstor Perlongher como uma resposta contrária à abundante poesia social dos anos 70 , que possui um valor comunicacional da linguagem e da poesia: “Cadáveres opta por engastar a denúncia numa linguagem [...] que resiste a esse valor comunicacional e, ao mesmo tempo, o impugna" (2012, p. 224).

Em "Néstor Perlongher: muerte lúbrica y transposición artística”, Roberto Echavarren (2002) usa a metáfora do megafone para demonstrar como Perlongher denuncia a morte no poema em questão e em outros que compõem o livro Alambres. Essa imagem é bastante pertinente pois, no referido texto poético, ao contrário de romper o silenciamento com uma introdução concisa das consequências da ditadura militar como acontece em Glosa, os cadáveres dos desaparecidos do período ditatorial irrompem repetida e obsessivamente em cada estrofe com o estribilho "Hay cadáveres", tal como o aumento e a expansão do som de um megafone.

O poema percorre um amplo e irônico panorama das mais variadas esferas da sociedade argentina nos quais se cria uma atmosfera de terror, como se observa no seguinte trecho:

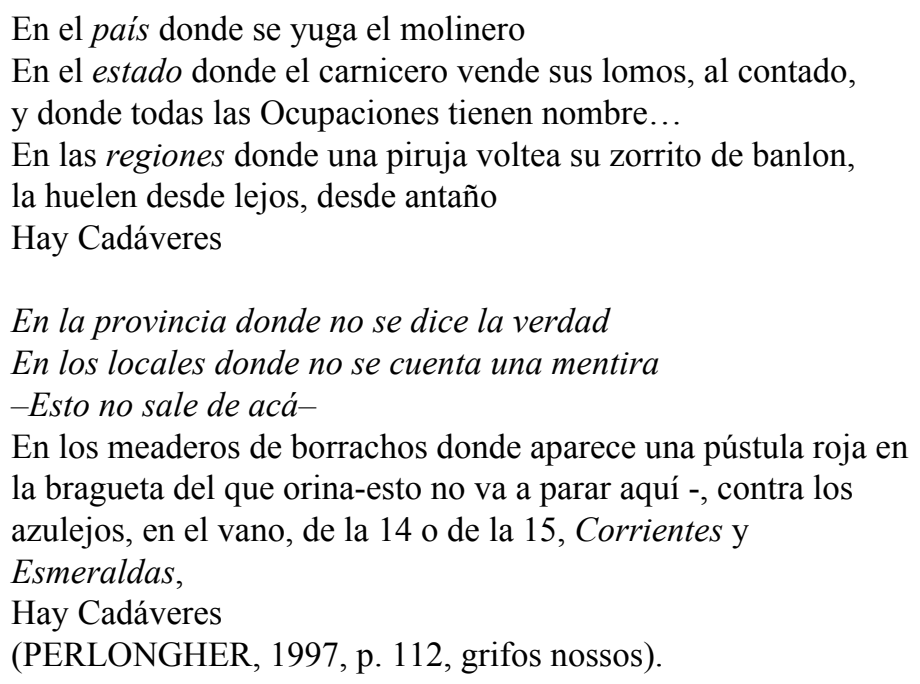

No fragmento, o silêncio diante da morte cria a atmosfera de terror, pela negação desses múltiplos setores sociais das mortes causadas pela ditadura militar. Sendo assim, simultânea ou antiteticamente ao aparecimento obsessivo da morte, no poema surge, em um movimento contrário, a sua negação. 
Estamos de acordo com Pablo Gasparini (2012) quando, em "No entremeio do trágico: Perlongher e os 'Cadáveres' da Nação", aponta que o estribilho é o decantamento do gozoso fluir neobarroso, movimento poético do qual Perlongher participa ativamente, "no sentido de ser aquilo que o poema não consegue assimilar" (p. 170). Ou seja, assim como em Glosa a escrita dos efeitos da ditadura militar irrompe em uma narração marcada pela morosidade poética, em "Cadáveres", o desaparecimento e morte causados pelo horror ditatorial interrompem uma escrita também caracterizada pelo deleite das palavras, apesar dessa interrupção ser obsessiva e, por isso, não concisa. Os cadáveres são "lo que [...] atraganta" (PERLONGHER, 1997, p. 112) o fluir poético e o silenciamento.

Sendo assim, no poema, a pessoalização profana a tragédia política e quebra o silêncio em torno da morte interditada, revelando o seu caráter abjeto na intimidade e no presente das pessoas/personagens. Como afirma Javier Gasparri (2012) mais acima, a política na poética perlongheriana é um olhar que se inscreve na sua imediatez política. Sendo assim, o "hay" do estribilho "Hay cadáveres" é uma presença indeterminada que irrompe no presente dessas pessoas, e não uma irrupção que está no destino político dos personagens, tal como ocorre em Glosa. Além disso, o horror histórico não é desconhecido no presente, mas um indesejável conhecimento: a paradoxal presença dos desaparecidos. Entretanto, essa ausência mortal é anunciada com um megafone.

Enfim, a representação do terrorismo de estado é feita de maneira distinta em Glosa e em "Cadáveres". Nesse, mostra-se a escuridão no meio de um presente aparentemente normal. Mas outra alternativa é mostrar que, quando a escuridão domina, a narrativa e os personagens de Glosa são como o viajante-narrador Marco Polo de Cidades invisíveis, romance de Ítalo Calvino, mesmo autor de "Leveza". O objetivo de suas viagens é o seguinte:

\footnotetext{
- Sim, o império está doente e, o que é pior, procura habituar-se às suas doenças. $\mathrm{O}$ propósito das minhas explorações é o seguinte: perscrutando os vestígios de felicidade que ainda se entreveem, posso medir o grau de penúria. Para descobrir quanta escuridão existe em torno, é preciso concentrar o olhar nas luzes fracas e distantes $(2017$, p. 70)
}

A centralidade e a dilatação narrativas nos instantes felizes da comunidade de amigos de Glosa jogam para um segundo plano a força política que irá pressionar alguns personagens nas prolepses do romance. No lugar do romance representar um lamento pelos catastróficos efeitos de uma violenta ditadura militar, mostra a alegria dos personagens-amigos em estar 
juntos e, no seu futuro político, mostra como essa alegria persiste em momentos tão graves de suas vidas em espaços alheios à dominação durante os quais experimentam uma forma de vida coletiva que não se reduz ao político no seu sentido mais estrito e violento. 


\section{BIBLIOGRAFIA}

ABBATE, Florencia. "La historia en las ficciones de Juan José Saer". In: SAER, Juan José. Glosa/El entenado. Edición crítica. Julio Premat (coord.) Poitiers, Córdoba: CRLA, Alción, 2010 .

El espesor del presente: tiempo e historia en las novelas de Juan José

Saer. Villa María (Argentina): Eduvim, 2014.

. "La posición estética de Saer". Crítica cultural, Santa Catarina, v. 5, n.

2, p. 315-324, 2010. Número especial. Disponível em: $<$ http://www.portaldeperiodicos.unisul.br/index.php/Critica_Cultural/article/view/698/652> Acesso em: 08 jan. 2014.

ADORNO, Theodor. "A posição do narrador no romance contemporâneo". In: Notas de Literatura I. São Paulo: Duas Cidades; Ed. 34, 2003.

AGAMBEN, Giorgio. "Ensaio sobre a destruição da experiência". In: Infância e história. Destruição da experiência e origem da história. Belo Horizonte: UFMG, 2005.

SC: Argos 2009.

. “O amigo". In: O que é o contemporâneo? e outros ensaios. Chapecó, . Desnudez. Buenos Aires: Adriana Hidalgo, 2011.

. "Bartleby, ou da contingência" In: Bartleby, ou da contingência / Bartleby, o escrevente: uma história de Wall Street. Belo Horizonte: Autêntica, 2015.

A comunidade que vem. Belo Horizonte: Autêntica, 2013.

. O que resta da Auschiwitz: o arquivo e a testemunha. São Paulo:

Boitempo, 2008.

. O uso dos corpos. São Paulo: Boitempo, 2017.

AIRA, César. "La intimidad". Boletín del Centro de Estudios de Teoría y Crítica Literaria, Rosário, n. 13-14, p. 1-8, dez. 2007-abr. 2008. Disponível em: $<$ http://www.celarg.org/int/arch_publi/aira_13_14.pdf>. Acesso em: 14 mar. 2016.

AMPUDIA, Sebastián Ramiro. "Las mujeres de Juan José Saer: un análisis de 'En la zona' desde la estética feminista". Gramma, Buenos Aires, v. 1, n. 4, 2012. Disponível em: $<$ http://p3.usal.edu.ar/index.php/gramma/article/view/3487> . Acesso em: 2 jun. 2017.

ARCE, Rafael. "La pasión de lo real". In: CONTRERAS, Sandra (ed.) Realismos: cuestiones críticas. Rosario: Centro de estudios de Literatura Argentina y Humanidades; Artes Ediciones, 2013 . 
. "Imaginación material y tropismos. Acerca del vínculo entre Juan José Saer y Nathalie Sarraute". Anuari de Filologia. Llengües i Literatures Modernes, Barcelona, n. 5, p. 1-19, 2015.2 Disponível em: $<$ http://revistes.ub.edu/index.php/AFLM/article/view/14724/17900>. Acesso em: 30 nov. 2015.

ASSIS, Machado de. "Memórias póstumas de Brás Cubas". In: Obra completa, vol. I. Rio de Janeiro: Nova Aguilar, 1994.

BAKTHIN, Mikhail. Problemas da poética de Dostoievski. 5 ed. Rio de Janeiro: Forense Universitária, 2013.

. "O banquete em Rabelais". In: A cultura popular na Idade Média e no Renastimento: o contexto de François Rabelais. São Paulo: Hucitec, 1987.

BALDERSTON, Daniel \& LUCERO, Nicolás. "Diálogos, risas y tropiezos en Glosa". In: SAER, Juan José. Glosa/El entenado. Edición crítica. Julio Premat (coord.) Poitiers, Córdoba: CRLA, Alción, 2010.

BARTHES, Roland. O prazer do texto. São Paulo: Perspectiva, 1987.

BASTOS, María Luisa. "Eficacias del verosímil no realista. Dos novelas de Juan José Saer". In: SAER, Juan José. Glosa/El Entenado. Edición crítica. Julio Premat (coord.) Poitiers, Córdoba: CRLA, Alción, 2010.

BAUMAN, Zygmunt. Amor líquido: Sobre a fragilidade dos laços humanos. Rio de Janeiro: Jorge Zahar, 2004.

. Modernidade líquida. Rio de Janeiro: Jorge Zahar, 2008.

BENJAMIN, Walter. "O narrador". In: Magia e técnica, arte e politica.São Paulo: Brasiliense, 2000.

BERGSON, Henri. O riso: Ensaio sobre a significação da comicidade. São Paulo: Martins Fontes, 2007.

BLANCHOT, Maurice. “La amistad”. In: La amistad. Madrid: Trotta, 1976. . La comunidad inconfesable. Madrid: Nacional, 2002.

BORGES, Jorge Luis. "El escritor argentino y la tradición" In: Obras completas. Buenos Aires: Emecé, 1974.

BRACAMONTE, Jorge. "Las tradiciones literarias latinoamericanas en Saer, Piglia y Aira". In: PATIÑO, Roxana; CALOMARDE, Nancy Calomarde (eds.) Escrituras latinoamericanas: Literatura, teoría y crítica en debate. Córdoba: Alción, 2013.

. "La importancia de Glosa en la obra de Juan José Saer". In: Los 
códigos de la transgresión. Lengua literaria, lengua política y escritura contemporánea en la narrativa Argentina. Córdoba: Jorge Sarmiento - Universitas libros/Facultad de Filosofía y Humanidades (UNC), 2007.

CALVINO, Ítalo. "Leveza". In: Seis propostas para o próximo milênio. São Paulo: Companhia das Letras, 1990.

. Cidades invisiveis. Companhia das Letras, 2017.

CLEASSON, Christian. "La conexión Onetti-Saer. La arbitrariedad del narrador en Los adioses y Glosa". Crítica cultural, Santa Catarina, v. 5, n. 2, p. 315-324, 2010. Número especial. Disponível em:

$<$ http://www.portaldeperiodicos.unisul.br/index.php/Critica_Cultural/article/view/705/660> Acesso em: 08 jan. 2014.

CONTRERAS, Sandra. "Glosa, un atisbo de fiesta". Paradoxa, Rosario, n. 6, 1991. Disponível em: <http://www.lectorcomun.com/archivos/files/5ContrerasParadoxa6.pdf>. Acesso em: 08 jan. 2014.

CORRADO, Omar. "Sonido, tiempo, forma: una escucha musical de los textos de Juan José Saer". Revista del ISM, Santa Fe, n. 5, 1996. Disponível em: $<$ https://bibliotecavirtual.unl.edu.ar/ojs/index.php/ISM/article/view/512> . Acesso em: 27 jul. 2017.

DALMARONI, Miguel. "El largo camino del "silencio" al "consenso". La recepción de Saer en la Argentina (1964-1987)”. In: SAER, Juan José. Glosa/El entenado. Edición crítica. Julio Premat (coord.) Poitiers, Córdoba: CRLA, Alción, 2010.

DALMARONI, M.; Merbilhaá, M. “'Un azar convertido en don’. Juan José Saer y el relato de la percepción”. In: JITRIK, Noé (dir.) Historia crítica de la literatura argentina, v.11. Buenos Aires: Emecé, 1999.

DEMA, Pablo. "El relato literario y la memoria colectiva". Borradores, Córdoba, v. VIII-IX, $2008 . \quad$ Disponível em $<$ http://www.unrc.edu.ar/publicar/borradores/Vol8-9/pdf/El\%20relato\%20literario\%20y\%201 a\%20memoria\%20colectiva.pdf $>$. Acesso em: 8 jan. 2014.

DERRIDA, Jacques. Dar (el) tiempo. La moneda falsa. Barcelona: Paidós Ibérica, 1995.

Barcelona, 1998. . "El arte de las memorias". In: Memorias para Paul de Man. Gedisa:

ECHEVARREN, Roberto. "Néstor Perlongher: muerte lúbrica y transposición artística". In: SCHWARTZ, Jorge (ed.). Cuadernos de Recienvenido. Homenaje a Néstor Perlongher, n. 18. São Paulo: Humanitas/FFLCH/USP, 2002.

ECO, Umberto. Confissões de um jovem romancista. São Paulo: Cosac Naify, 2013. 
FLISEK, Agniezka B. "Juan José Saer y el relato de la memoria". The Barcelona Review, Barcelona, n. 30, mai.-jun. 2002. Disponível em: $<$ http://www.barcelonareview.com/30/s_abf.htm> Acesso em: 09 jan. 2014.

FORNET, Jorge. Los nuevos paradigmas - prólogo narrativo al siglo XXI. La Habana: Letras cubanas, 2006.

GARRAMUÑO, Florencia. "Las ruinas y el fragmento. Experiencia y narración, en El Entenado y Glosa". In: SAER, Juan José. Glosa/El entenado. Edición crítica. Julio Premat (coord.) Poitiers, Córdoba: CRLA, Alción, 2010.

A experiência opaca: Literatura e desencanto. Rio de Janeiro:

EdUERJ, 2012.

GASPARINI, Pablo. "No entremeio do trágico: Perlongher e os 'Cadáveres' da Nação." In: Estudos de literatura brasileira contemporânea, Brasília, n. 29 , p. 165-178, 2007. Disponível em: $<$ http://www.redalyc.org/articulo.oa?id=323127092011> Acesso em: 23 dez. 2014.

GASPARRI, Javier. Poesía y Política en Néstor Perlongher. In: Anclajes, Santa Rosa, v. 16, n. 1, jun. 2012. Disponível em $<$ http://www.scielo.org.ar/scielo.php?script=sci_arttext\&pid=S1851-46692012000100002\&ln $\mathrm{g}=\mathrm{es} \& \mathrm{nrm}=\mathrm{iso}>$. Acesso em : 04 jan. 2015.

GIORDANO, Alberto. "El efeto de irreal". In: SAER, Juan José. Glosa/El entenado. Edición crítica. Julio Premat (coord.) Poitiers, Córdoba: CRLA, Alción, 2010.

GRAMUGLIO, María Teresa. "El lugar de Saer”. Crítica cultural, Santa Catarina, v. 5, n. 2, p. 2010. 325-347, Número especial. Disponível em: $<$ http://www.portaldeperiodicos.unisul.br/index.php/Critica_Cultural/article/view/695/650> Acesso em: 08 jan. 2014.

. "Una imagen obstinada del mundo". In: SAER, Juan José. Glosa/El entenado. Edición crítica. Julio Premat (coord.) Poitiers, Córdoba: CRLA, Alción, 2010 .

; SAER, Juan José. "Razones". Crítica cultural, Santa Catarina, v. 5, n. 2, p. 315-324, 2010. Número especial. Disponível em: $<$ http://www.portaldeperiodicos.unisul.br/index.php/Critica_Cultural/article/view/695/650> Acesso em: 08 jan. 2014.

GINZBURG, Natalia. Léxico familiar. São Paulo: Cosac \& Naify, 2009.

GUISASOLA, Dana. "Una posible glosa de Glosa". Analecta Malacitana electrónica, Málaga, n. 36, jun. 2014. Disponível em: $<$ http://www.anmal.uma.es/numero36/Glosa.pdf $>$. Acesso em: 10 fev. 15.

HALBWACHS, M. A memória coletiva. São Paulo: Centauro, 2006. 
HUIZINGA, Johan. Homo ludens: o jogo como elemento da cultura. São Paulo: Perspectiva: 2014.

JANNAI, Milly E. “Aproximaciones a Glosa, de Juan José Saer”. Espéculo. Revista de estudios literarios, Madrid, n. 38, mar.-jun. 2008. Disponível em: $<$ http://pendientedemigracion.ucm.es/info/especulo/numero38>. Acesso em: 08 jan. 2014.

KOHAN, Martín. “Glosa, novela política”. In: RICCI, Paulo (ed.). Zona de prólogos. Buenos Aires: Seix Barral, 2011.

LEITE, Lígia Chiappini Moraes. O foco narrativo.São Paulo: Ática, 2007.

LEMINSKI, Paulo. “Inutensílio". In: Anseios cripticos. Curitiba: Criar, 1986. Disponível em: $<$ http://www.elsonfroes.com.br/kamiquase/ensaioPL2.htm>. Acesso em 9 jun. 2017.

LÓPEZ, Silvana. "Temporalidad, fantasma y narración en 'Glosa' de Juan José Saer". Chasqui. Revista de literatura latinoamericana, Arizona, v. 41, n. 2, nov. 2012. Disponível em: < http://www.jstor.org/stable/43589465>. Acesso em: 13 mar. 2017.

LUKÁCS, Georg. A teoria do romance. 2. ed. São Paulo: Duas Cidades; Editora 34, 2009.

LUPPI, Juan P. "Astillas de experiencia y de memoria. Problemas del testigo en Glosa de Juan José Saer”. Hologramática. Revista de Ciencias Sociales Comunicación, Relaciones Laborales, Literatura, Educación y Trabajo Social, Buenos Aires, v. 2, n. 4, 2007. Disponível em: <http://www.cienciared.com.ar/ra/usr/3/551/n7_vol4pp37_59.pdf $>$. Acesso em: 10 fev. 15.

MALTZ, Hernán. "Lo imborrable de Saer, lo imborrable de la amistad". LL Journal. PhD Program in Hispanic and Luso-Brazilian Literatures and Languages, New York, v. 8, n. 2, 20133. Disponível em: <https://ljournal.commons.gc.cuny.edu/2013-2-maltz-texto $>$. Acesso em: 17 jul. 17.

MARTÍNEZ, María Bermúdez. "Vislumbres críticos: un horizonte de 'deseo' y 'alucinación'”. In: SAER, Juan José. Glosa/El entenado. Edición crítica. Julio Premat (coord.) Poitiers, Córdoba: CRLA, Alción, 2010.

MARTÍNEZ, J.L. et al. “Artifícios da criação. Uma conversa com Juan José Saer”. Novos estudos - CEBRAP, São Paulo, n. 73, nov. 2005. Disponível em: $<$ http://www.scielo.br/scielo.php?script=sci_arttext\&pid=S0101-33002005000300012\#nt01> . Acesso em: 08 jan. 2014.

MIRANDA, Breno A. S. "Uma provável ética na antifesta: união, compromisso e contraponto entre vida, política e narração em Glosa, de Juan José Saer”. Em tese, Belo Horizonte, v. 20, n. 2, mai.-ago. 2014. Disponível em: $<$ http://www.letras.ufmg.br/poslit/08_publicacoes_pgs/Em\%20Tese $\% 2017 / 17-1 /$ TEXTO $\% 20$ 1\%20BRENO.pdf>. Acesso em: 08 jan. 2014. . Acesso em: 10 fev. 15.

MIRAUX, Jean-Philippe. El personaje en la novela. Génesis, continuidad y ruptura. Buenos Aires: Nueva Visión, 2005. 
MONTALDO, Graciela. "Una exploración de los límites”. In: SAER, Juan José. Glosa/El entenado. Edición crítica. Julio Premat (coord.) Poitiers, Córdoba: CRLA, Alción, 2010.

MORENO, Carlos Domínguez. "El vínculo de la amistad" In: Los registros del deseo, del afecto, amor y otras pasiones. Bilbao: Desclee de Brouwer, 2001. Disponível em : $<$ https://bambancillo.files.wordpress.com/2010/04/amistad_dominguez.doc $>$ Acesso em: 15 mar. 2016.

NUNES, Benedito. O tempo na narrativa.São Paulo: Edições Loyola, 2013.

ORTEGA, Francisco. Genealogias da amizade.São Paulo: Iluminuras, 2002.

Janeiro: Relume Dumará, 2000.

Para uma política da amizade: Arendt, Derrida, Foucault. Rio de

OUBIÑA, David. "La extenuación”. In: Lecturas de Juan José Saer: una celebración de "la zona”, 2005. Anais eletrônicos ... Buenos Aires: Universidad de San Andrés, MALBA,2005. Disponível em: $<$ http://repositorio.udesa.edu.ar/jspui/bitstream/10908/445/1/\%5bP\%5d\%5bW\%5d\%20DT38Lecturas\%20de\%20Juan\%20Jos\%C3\%A9\%20Saer.pdf>. Acesso em: 13 mar. 2017.

PAULS, Alan. "Gag”. In: SAER, Juan José. Glosa/El entenado. Edición crítica. Julio Premat (coord.) Poitiers, Córdoba: CRLA, Alción, 2010.

PEREIRA Jr., Antônio D. Glosas e silêncio em Juan José Saer. 124f. Dissertação (Mestrado em Teoria e História Literária) - Instituto de Estudos da Linguagem, Universidade Estadual de Campinas, São Paulo, 2006. Disponível em $<$ http://www.bibliotecadigital.unicamp.br/document/?code $=$ vtls000384518> Acesso em: 08 jan. 2014.

PERLONGHER, Néstor. “Cadáveres”. In: Poemas Completos (1980-1992). Buenos Aires: Seix Barral, 1997.

PIGLIA, Ricardo. "La amistad en Saer”. In: SAER, Juan José. Glosa/El entenado. Edición crítica. Julio Premat (coord.) Poitiers, Córdoba: CRLA, Alción, 2010.

Piglia, Ricardo; Saer Juan José. Diálogo. Santa Fe (Argentina): Centro de Publicaciones Universidad Nacional del Litoral, 1995.

. "Prólogo". In: Tres propuestas para el próximo milenio (y cinco dificultades). Buenos Aires/Ciudad de México: Fondo de Cultura Económica,2001.

PLATÃO. O Banquete. 3. ed. Belém: ed. ufpa, 2011.

PRIETO, Martín (comp.). Juan José Saer: una forma más real que la del mundo. Buenos Aires: Mansalva, 2016. 
PREMAT, Julio. La dicha de Saturno. Escritura y melancolía en la obra de Juan José Saer. Rosario: Beatriz Viterbo, 2002.

. "Saer, un escritor del lugar". In: Héroes sin atributos: Figuras de autor en la literatura argentina. Buenos Aires: Fondo de Cultura Económica, 2008.

"Introducción". In: SAER, Juan José. Glosa/El entenado. Edición crítica. Julio Premat (coord.) Poitiers, Córdoba: CRLA, Alción, 2010.

PREMAT, J. et al. "Entrevista a Juan José Saer". In: SAER, Juan José. Glosa/El entenado.Edición crítica. Julio Premat (coord.) Poitiers, Córdoba: CRLA, Alción, 2010.

QUEIROZ, Maria José de. A literatura e o gozo impuro da comida. Rio de Janeiro: Topbooks, 1994.

RICCI, Paulo. “La condición inmortal”. 2009. Trabalho inédito.

. "La condición inmortal: Políticas y poéticas de la amistad en la narrativa de Saer”. 2011. Trabalho inédito.

RICOEUR, Paul. A memória, a história, o esquecimento. Campinas: Editora da Unicamp, 2007.

SAER, Juan José. Glosa/El entenado. Edición crítica. Julio Premat (coord.) Poitiers, Córdoba: CRLA, Alción, 2010.

. Glosa. $5^{\mathrm{a}}$ ed. Buenos Aires: Seix Barral, 2013.

. El río sin orillas. Buenos Aires: Seix Barral, 2012. E-book.

. La grande. Barcelona: Rayo verde, 2017. E-book.

. La mayor. Buenos Aires: Seix Barral,1998.

. Lo imborrable. Buenos Aires: Seix Barral, 2012. E-book.

Barral, 2000.

. "El arte de narrar". In: El arte de narrar (1960-1975). Buenos Aires: Seix . El concepto de ficción. Buenos Aires: Ariel, 1997.

. Trabajos. Buenos Aires: Seix Barral, 2005.

; VALLE, Gustavo. "Una incertidumbre elocuente (entrevista con Juan José Saer)". Letras libres, Madrid, n. 09, jun. 2002. Disponível em: $<$ http://www.letraslibres.com/mexico-espana/la-incertidumbre-elocuenteentrevista-juan-jose-s aer>. Acesso em: 30 nov. 2016. 
; ABBATE, Florencia. "El legado de Juan José Saer. El principio de incertidumbre". Revista N. Clarín.com, Buenos Aires, 01 out. 2005. Disponível em: $<$ http://edant.clarin.com/suplementos/cultura/2005/10/01/u-01014517.htm>. Acesso em: 30 nov. 2016.

; PIGLIA, Ricardo. Diálogo. Santa Fe: Centro de Publicaciones Universidad Nacional del Litoral, 1995.

SARLO, Beatriz. "La condición mortal”. In: SAER, Juan José. Glosa/El entenado. Edición crítica. Julio Premat (coord.) Poitiers, Córdoba: CRLA, Alción, 2010.

. "La política, la devastación”. In: SAER, Juan José. Glosa/El entenado. Edición crítica. Julio Premat (coord.) Poitiers, Córdoba: CRLA, Alción, 2010.

. "Narrar la percepción". Crítica cultural, Santa Catarina, v. 5, n. 2, p.

315-324, 2010. Número especial. Disponível em:

$<$ http://www.portaldeperiodicos.unisul.br/index.php/Critica_Cultural/article/view/695/650>

Acesso em: 08 jan. 2014.

Aires: Siglo XXI, 2005.

. Tiempo pasado. Cultura de la memoria y giro subjetivo. $2^{\mathrm{a}}$ ed.Buenos . Zona Saer. Santiago de Chile: Ediciones Universidad Diego Portales, 2016.

SCAVINO, Dardo. "El Ser de Saer". In: SAER, Juan José. Glosa/El entenado. Edición crítica. Julio Premat (coord.) Poitiers, Córdoba: CRLA, Alción, 2010.

STEWART, Susan. El ansia. Narrativas de la miniatura, lo gigantesco, el souvenir y la colección. Rosario: Beatriz Viterbo, UNR, 2013.

WOOD, James. Como funciona a ficção. São Paulo: Cosac Naify, 2012. 